$$
\begin{aligned}
& \text { الاتجاه الوطني } \\
& \text { فى شعر همهد نضل إسماعيل } \\
& \text { دراسة فى الرؤى والمظامين }
\end{aligned}
$$

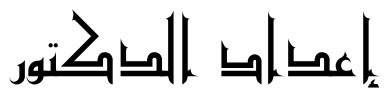

$$
\begin{aligned}
& \text { هصطنى عبد اللطيف أحهد أبو طه } \\
& \text { مدرس الأدب والنقد بالكلية . }
\end{aligned}
$$


$$
\text { - OHE- }
$$ 
بسم الله الرحمن الرحيم

\section{هقدهة البحث}

الحمد الله واهب الفضل ، ومُسدى النعم ، ومُجزلٍ الخير ، ومانج

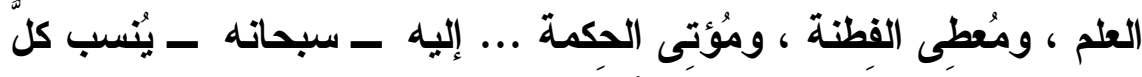

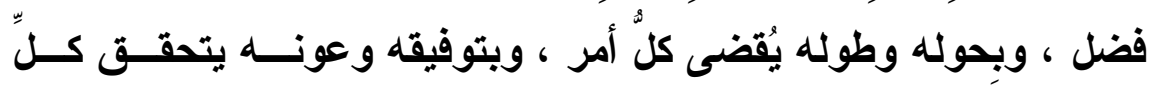

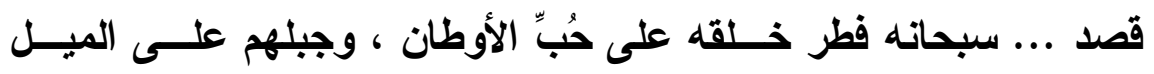

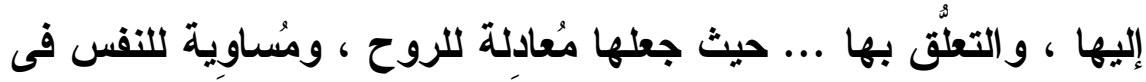

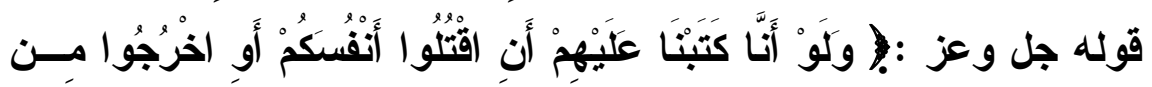

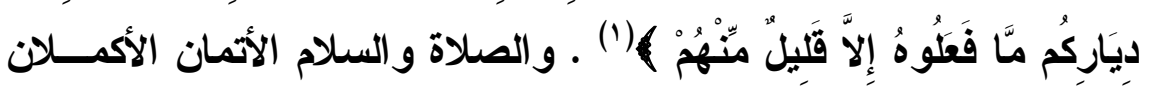

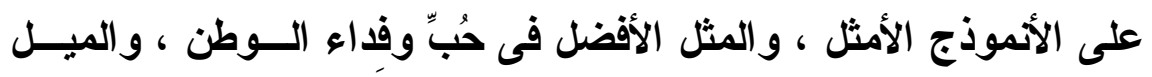

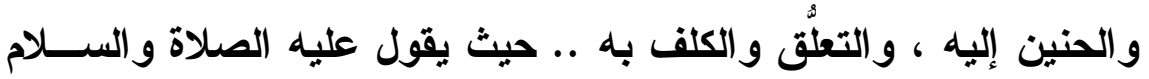

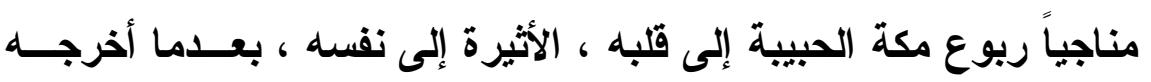

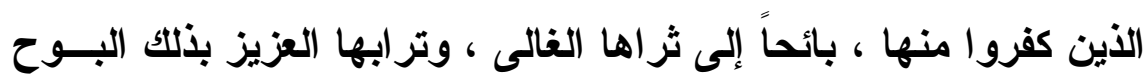

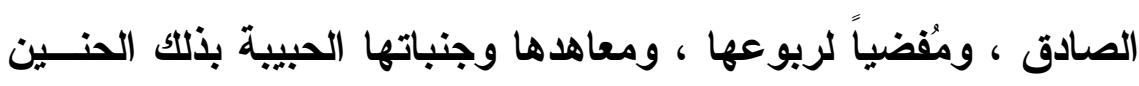

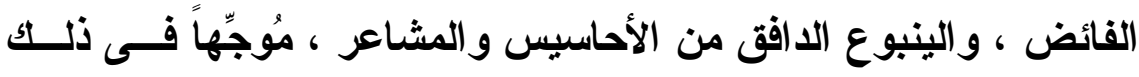

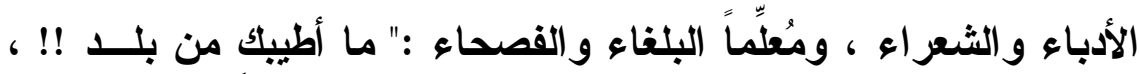

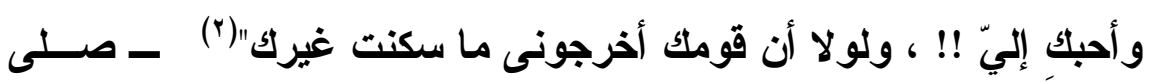
الله عليه ، وعلى آله وصحبه الميامين الأطهار ..

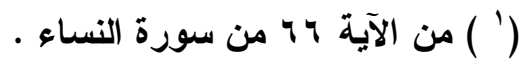

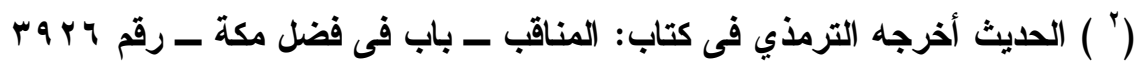

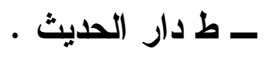




\section{פبת}

فهذه دراسة أدبية لرؤى ومضامين اتجاه شعرى شـاع فى نتــاج واحدِ من أبرز شعراء الجيل الماضى الأى ظهر منذ أوائل العشرينات فى مصر ، أما عن الاتجاه الثعرى فهو الاتجاه الوطني ، وأمـا عن الثـــاعر فهو محمد فضل إسماعيل - ذللك الأى سرى حُب الوطن فـى عروقــهـ ، وجرى فى دمه ، و استقرّ فى أعماقه ، وهز” كيانه ... حيــث يمكنتـــا أن

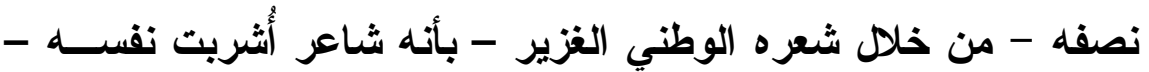
منذ نعومة أظفاره - الوطنية ، منطلقاً فى ذلك مــن إيمانــهـ الصـــادق ، وعقيدته الصحيحة .. فحبُّ الوطن من الآيّين ، وهو من الفطر الســليمة

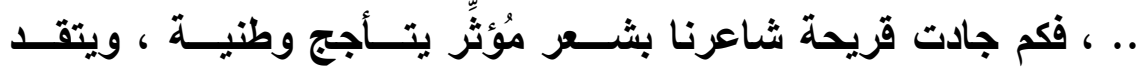
حماسة ، ويُعبِرٌ -من خلاله- عما يكنّه لوطنه من حُب عميـق ، ومهــا يأمله له من بناء ونهضة وخير عميم ، وذلك من خلال صرُ اخه المتكرر فى بنى وطنه ، ودعوته الملحّة إياهم إلى أن يتسلحوا بالأخلاق والعلـــ

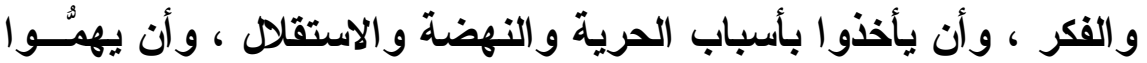

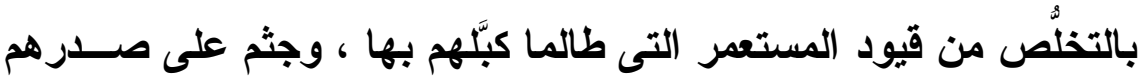

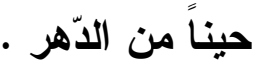
كذلك يبدو حُبٌْ الشـاعر الصادق لوطنه ، ويظهر حرصه الثـــيد على ما فيه الخير والرشـاد لأبنائهه ، ويتأكد ذلكا الحُبّ لايه مــن خــله إثـادته بقادة الحركة الوطنية ، وروادها فى عصره ، وتنويهه بفعـالهم رهية

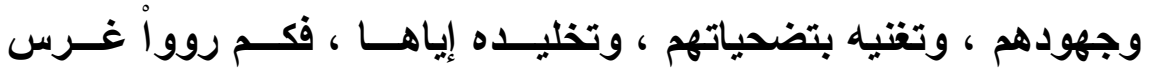

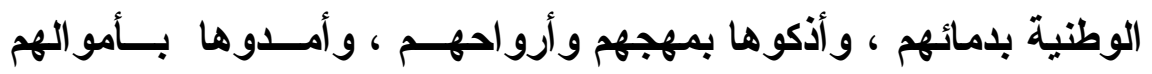
وعتادهم ، متحمّلين فى سبيل بناء ونهضة وحريــة واســتقلل وطـنهم 
الويلات ومُستعذبين العــذابات ، ومسـتطيبين الآلام ، مــكين الــروح الوطنية فى نفوس بنى وطنهم ..

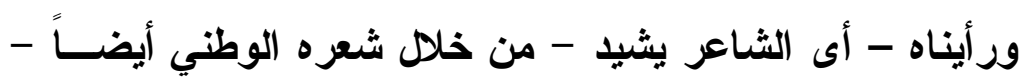

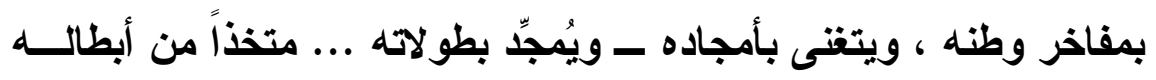

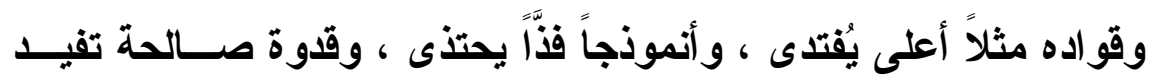

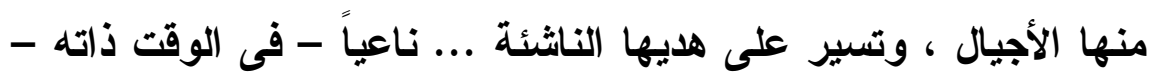

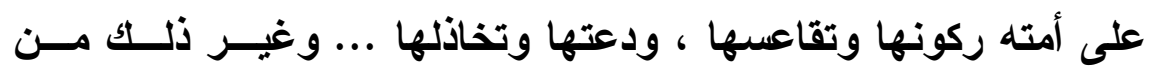

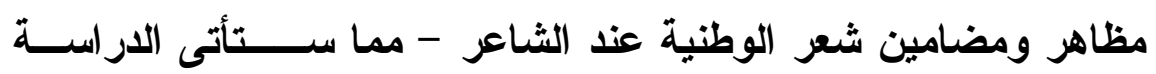

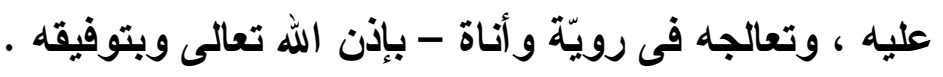

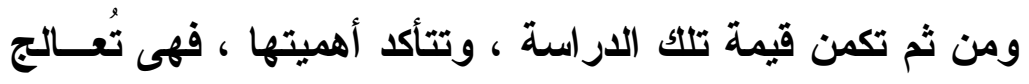

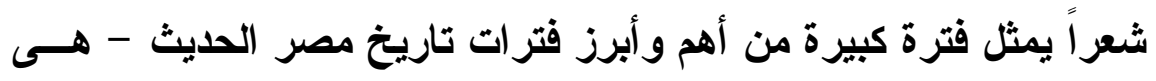

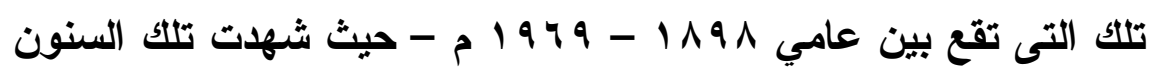

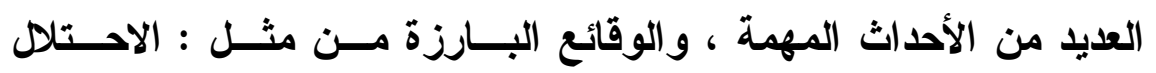
البريطاني البغيض ، واستئثاره بثروات البلاد دون العباد ، وتأميم قتــــاه

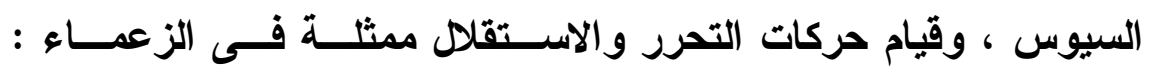

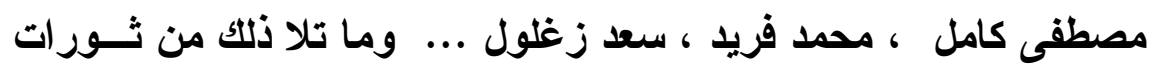

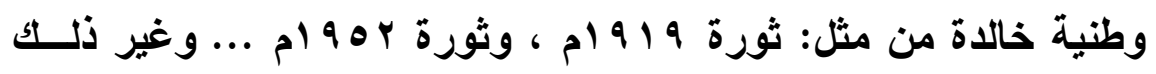

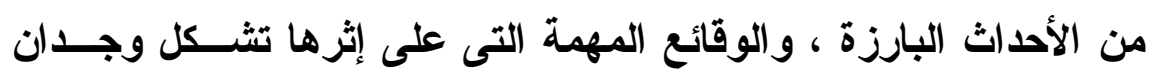
مصر ، وصار لها بعد ذلك كيان مستقل ، ووجود معترف بله بله بين الــاندول

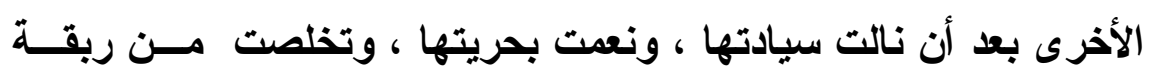

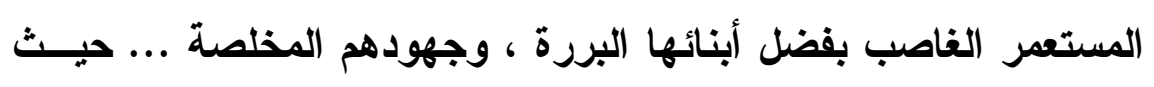

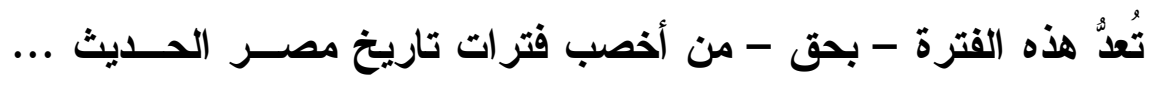
يُضاف إلى ذلك أهمية الثعر الوطني بعامه وقيمتــهـ الكبيــرة ، وأثــره 
العظيم ، وسمو مقصده ، وعظيم فائدته بين فنون الشعر الأخرى ، فــــ من شكك فى أن الأدب الوطني أدب سام يتبنى رسالة سامية .. حيث يقوم بدوره الفقّال فى النهوض بالأمة و الارتقاء بمو اطنيها ، و الأخذ بأيسـيهم

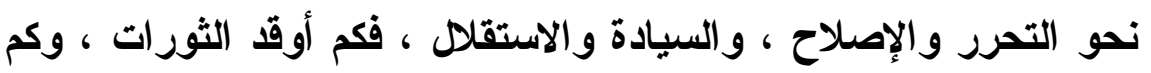

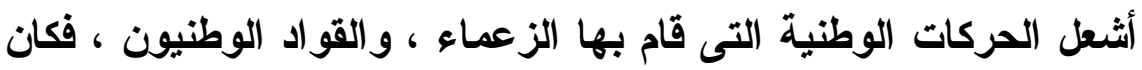
يشيد بهؤلاء القو اد المخلصين و الوطنيين الغيورين ، ويُلهـبـ مشـــاعر

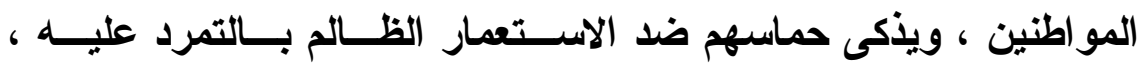

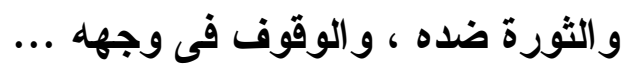

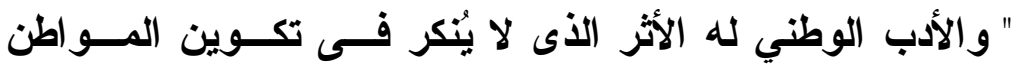

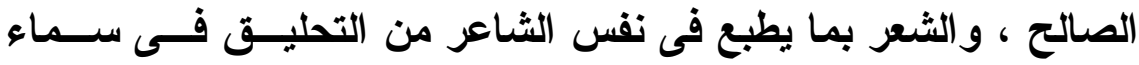

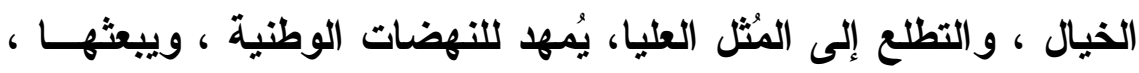

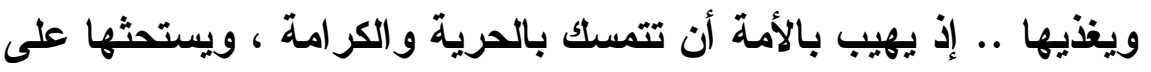
النفور من الذل وإباء الضيم ، ويُحبِب إليها الثــورة علــى الاستـتعمار

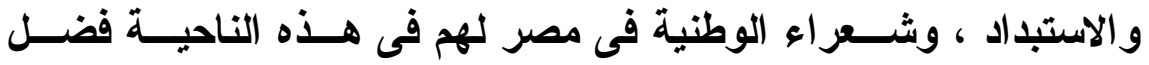

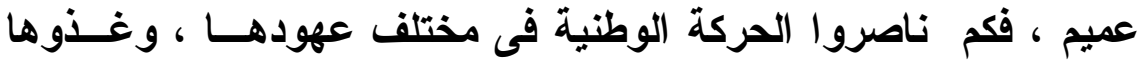

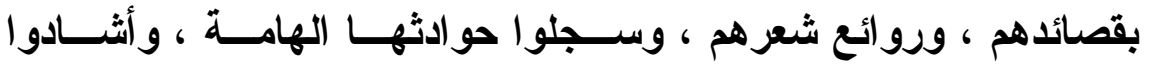

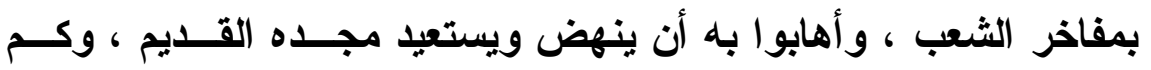

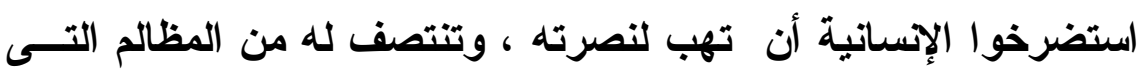

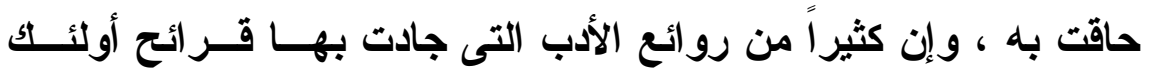
الثعر اء كاتت معالم للحركة الوطنية ، وكان الثباب يحفظها عن ظهـر

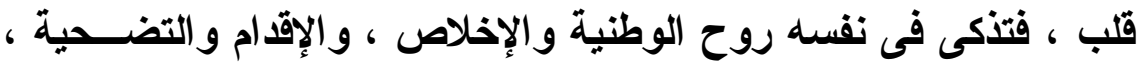


وكم من قصيدة أوبيت من الشعر قـــ حرّكــت المشـــاعر فــى نفـوس المو اطنين ، وستحركها على الدوام مهما تقادمت عليها الأعوام (1). وإذا كان لكل عمل من دافعٍ يدفع إليه، ودواع تدعوا إليه فـإننى

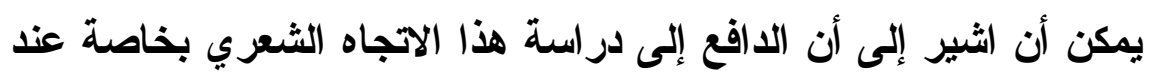
الشاعر يتمثل فى غزارته وتثوّعه ، وقوته وجودته ، فهو أى - الثاعر - وإن كان شمولي الفكرة .. تنوعت اتجاهات شعره ، وتعددت مضامينه بين شعرٍ ديني ، واجتماعي ، وشعر فكاهة وسخرية ... إلا أن الاتجــاه

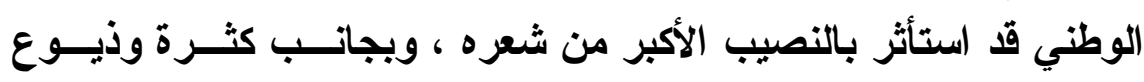
الشعر الوطني عند الشاعر فهو جيا يأتى - فى أغلبه- فى درجة عالية من القوة والنضوج ، بما يتوافر عليه من مظــاهر الجمــال ، ومعــالم

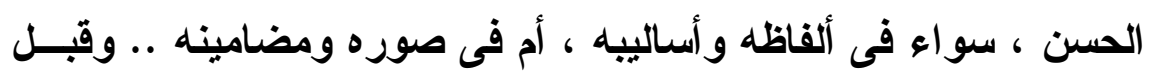

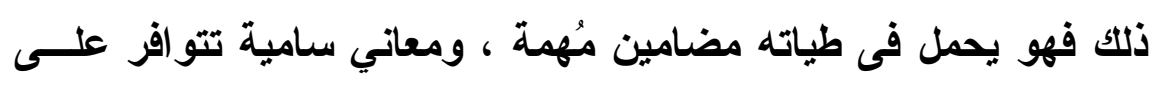
العديد من القيم العُليا ، والمثل النادرة التى من شأنها أن تسمو بمقاصد

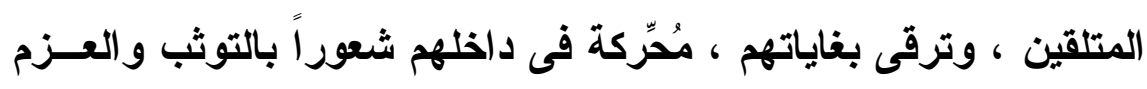
نحو تحقيق النهضة والبناء ، والحرية والاستقلال ، والرقي و والازدهــار لوطنهم ينضم إلى تلك الأسباب كون ذلك الثعر الوطني لـــى الثـــاعر يُجسِّ فترة من أبرز الفترات التى مرت بمصر .. حيث حفلت تلك الفترة

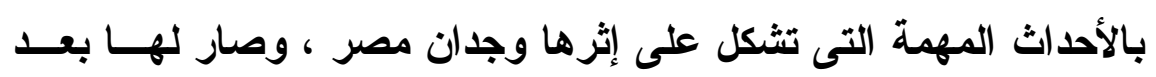

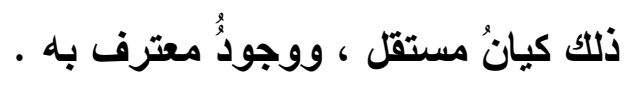

(' ) شعر اء الوطنية فى مصر - عبد الرحمن الرافعي - صـ ل، ل ط دار القومية

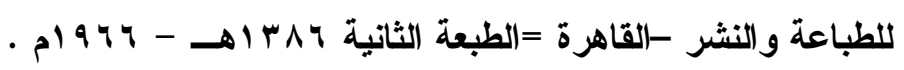


هذا وستقع دراستتا تلك - بفضل الله وبتوفيقه - بعد المقدمسة

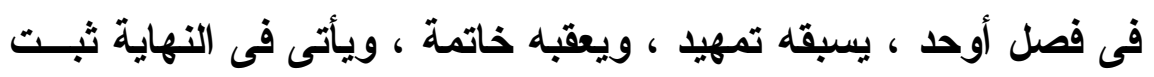
بالمصادر و المر اجع التى أفادت منها الدراسة.

أما التمهيل فجاء بعنوان : "الثـاعر محمد فضل إسماعيل حيــاةً وفنَّا ومؤثرات " ووقع فى فكرتين رئيستين :

\section{الأولـبعنو ان : الشاعر الهو لد والنشأة والوفاة .}

\section{والثانية بعنو ان: شعر عحمد فضل إسماعيل ، وشاعريته .}

بينما حمل فصل الارسة ذلك العنوان : الأبعاد الفكرية ، والآفاق

الموضوعية لثعر الوطنية عند الثاعر ، وتنتظم تلك الفكرة الرئيسة فى لفي

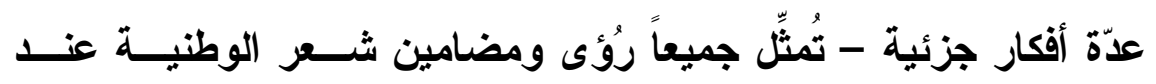

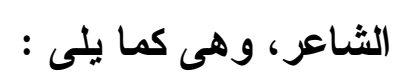

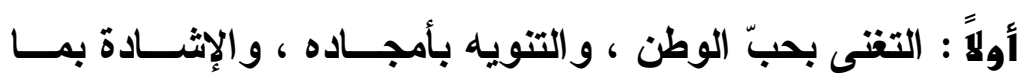

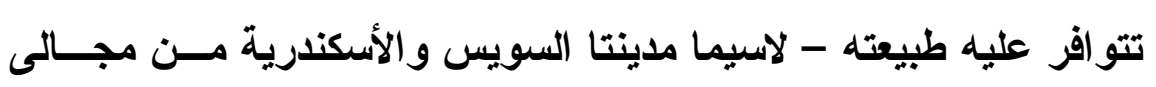

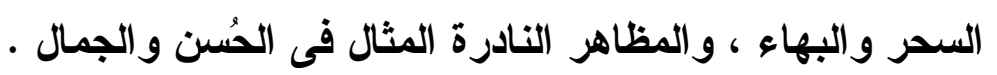

ثانياً: تجسيد المعاناة ، وتصوير الاضطهاد الواقعين على كاهل

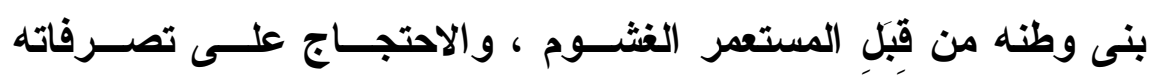

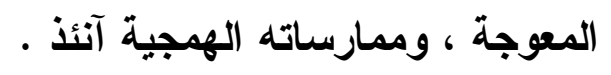

ثالثاً: الإثادة بزعماء الوطنية ، وباعثى نهضتها ، وقادة الأمة

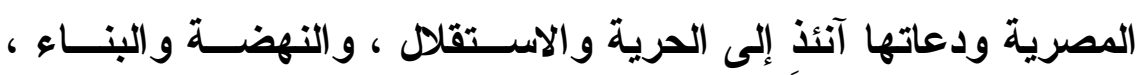

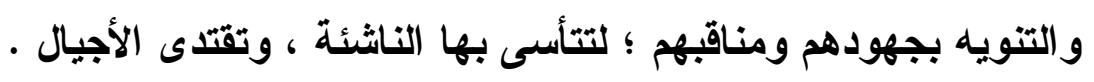


رابعاً : حث بنى الوطن على العمل على ما فيه نهضـــة ورقــي

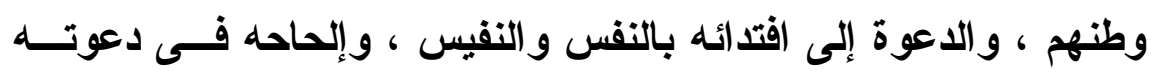

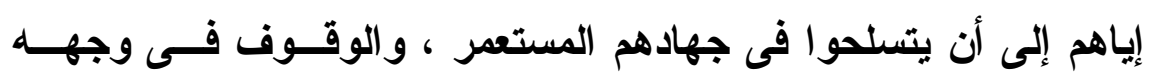

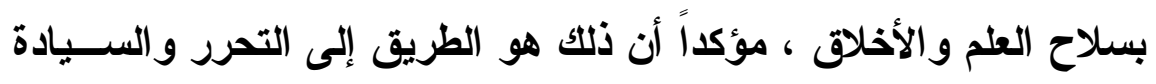
، و السبيل إلى التقام و الريادة .

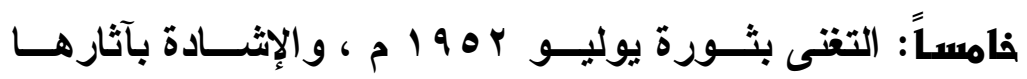

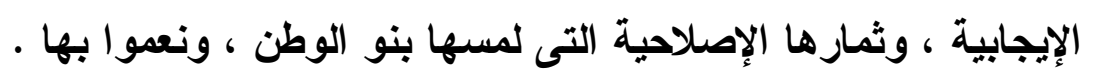
ونلتقى بعد ذلك بخاتمة الدراسة ... حيث نتعرف من خلالها على أبرز النتائج ، ونقف فيها على أهم الملحوظات التى أسفر عنها

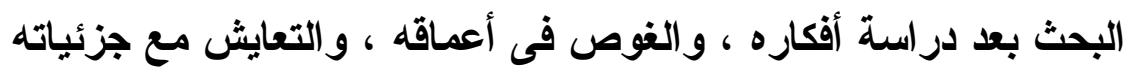

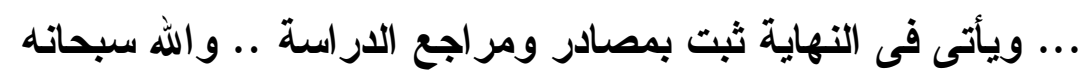

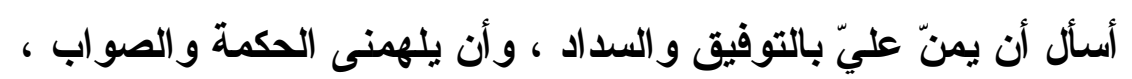

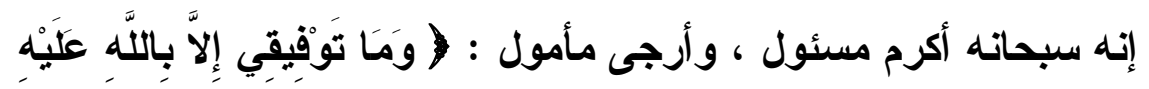

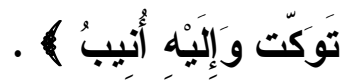
الباحث 
$$
-0 \leqslant Y-
$$ 


\section{التمهيد}

\section{الشاعر هممد نضل إسماعيل حياة وفنّا وهؤثرات .}

\section{ويتظمن فكرتين : الأوله : الشاعر الهو لد والنشأة والوفاة .}

الثانية : شعر محمد فضل إسماعيل وشاعريته

\section{الأولى : الثاعر محمد فضل إسماعيل المولا والنشأة والوفاة .}

وُلدا الثاعر محمد فضل إسماعيل فى أسرة رقيقة الحال ، كثيرة

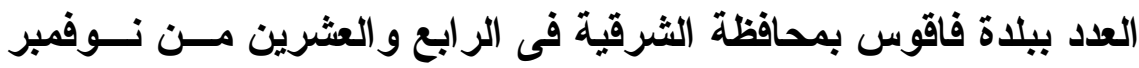

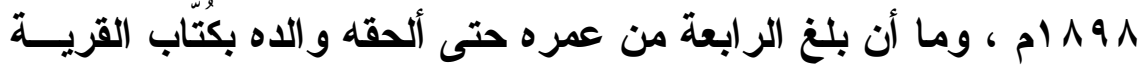

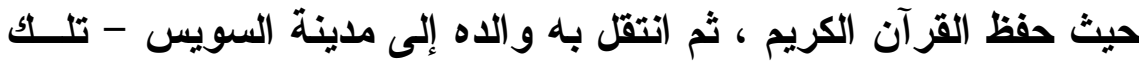
المدينة الأثيرة إلى نفس الثاعر ، القريبة من قلبه ، و التى كان له معها فيما بعد العديد من الوقفات فى شعره - انتقل الثاعر إلى تلك المدينة ،

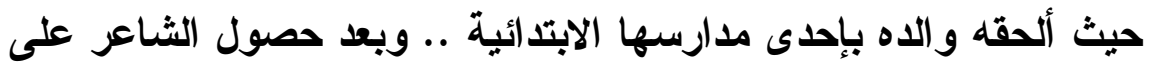
الشهادة الابتدائية لم يشأ والاه - بالرغم من ضيق ذات اليأ اليأ - أن يكون

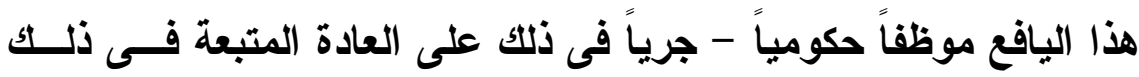

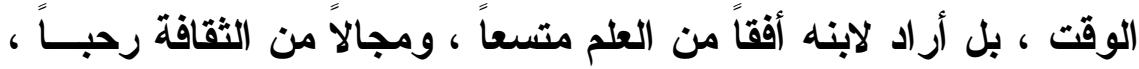
وقد تمثل ذلك فى تعلم علوم الدين و الثريعة من توحيد وتفسير وحديث الائه

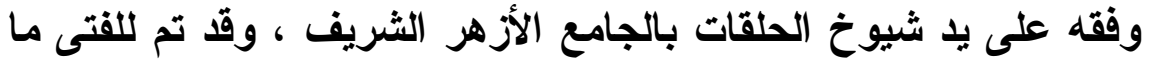
أراده له و الده ، حيث بقي عامين كاملين فى رحساب الجـامع الأزهـر

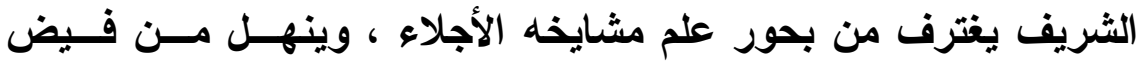
علمائه النجباء فى شتى فنون العلم و المعرفة . 


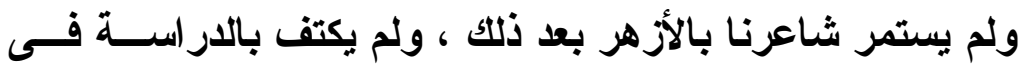

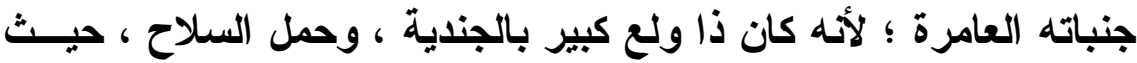

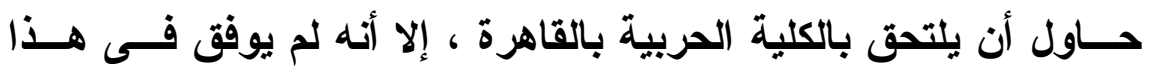

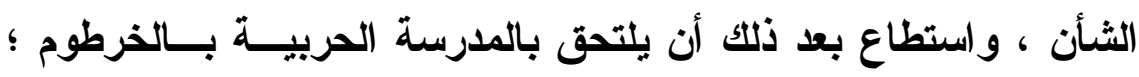

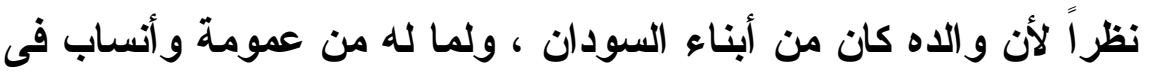

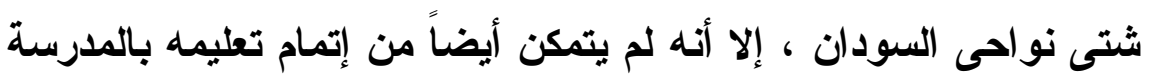

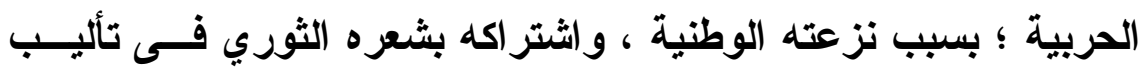

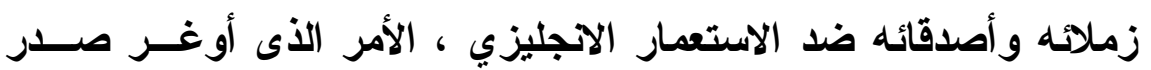

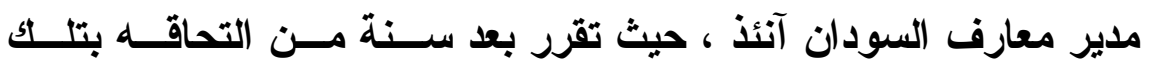

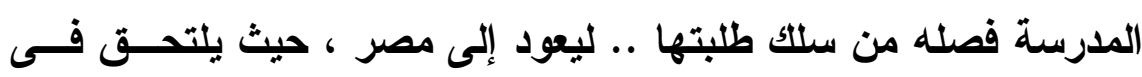

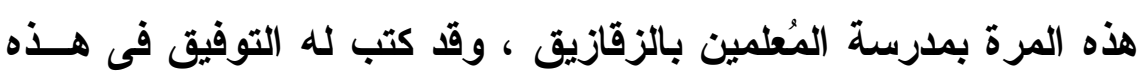

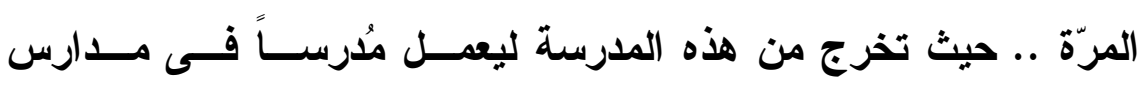
السويس الابتدائية .

وحين اثتتات وطأة الثاعر على الاستعمار وأعوانه من الأنتاب

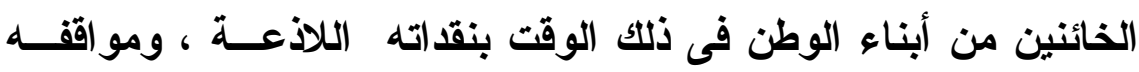

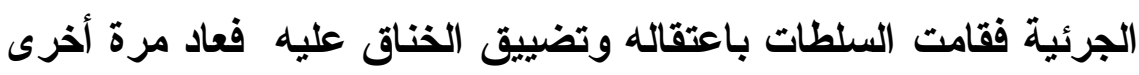

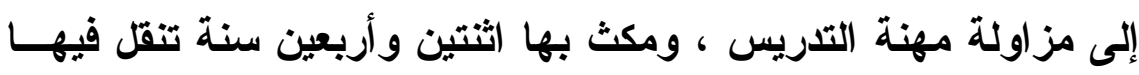

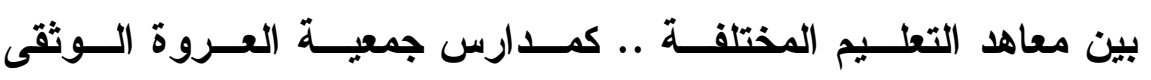

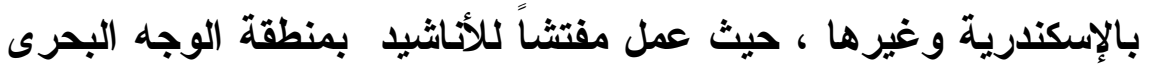

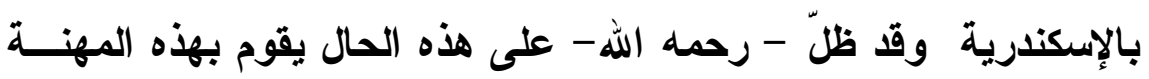

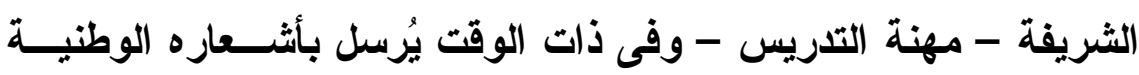

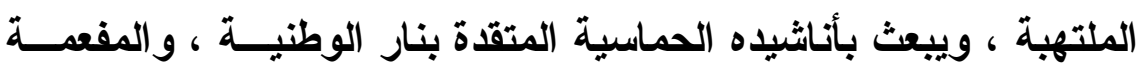


بحبه الثديد لوطنه ، و التى من شــأنها أن تــنكى شــور الجمـاهير ،

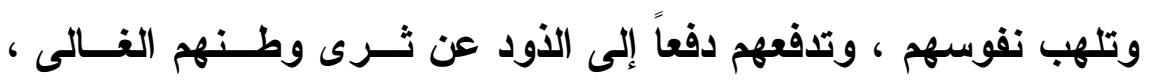
و الوقوف فى وجه أعدائه من المستعمرين الغاشمين ، والأنناب الخائنين

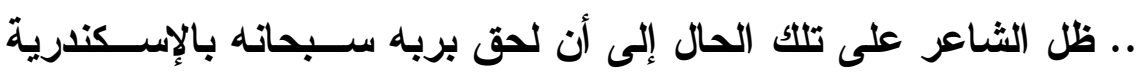

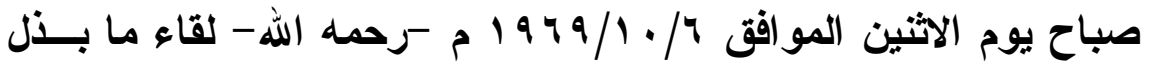

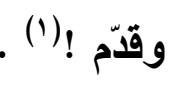

\section{الثاتبة : شعر محمد فضل إسماعيل وشاعريته :}

وُهب الثاعر محمد فضل إسماعيل موهبـة شـعرية كبيـرة ،

اتضحت معالمها فى شعره لاسيما الوطني ، حيث إن لله فى هذا الآجـــاه

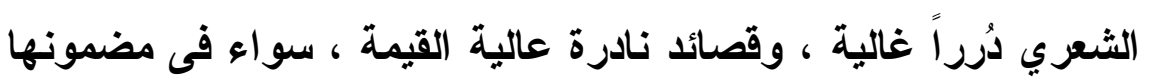

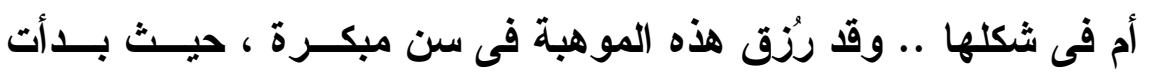

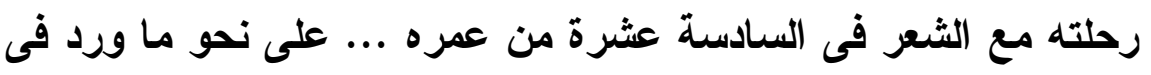

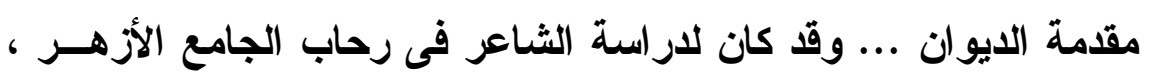

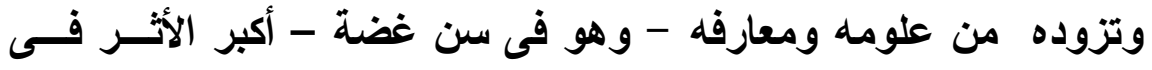

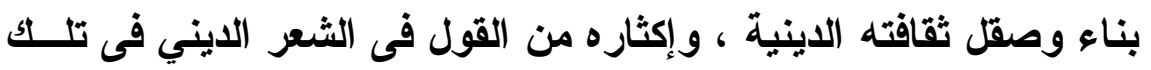

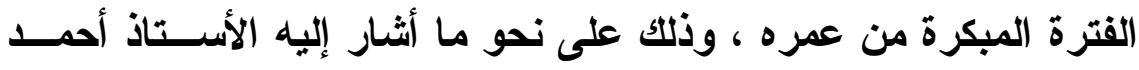

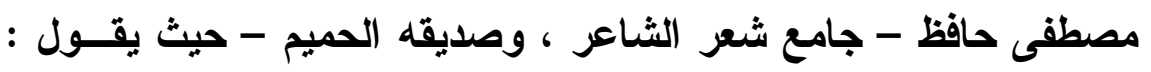

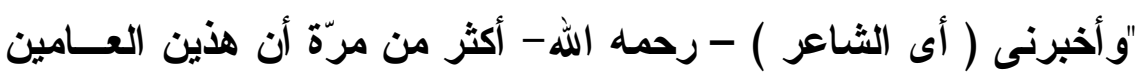

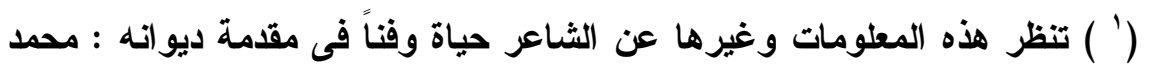

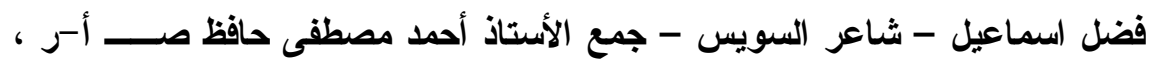

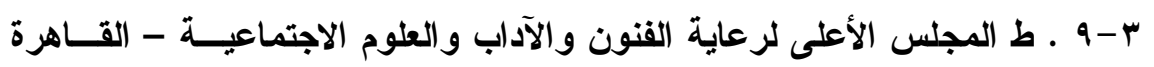

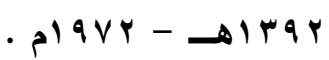


( يقصد العامين الذين درس فيهما فى رحاب الجامع الأزهر ) كانــا ذوى أثر بعيد فى تكوينه ، وتوجيهه إلى تعثق علوم العربية ، وتذوق الثعر

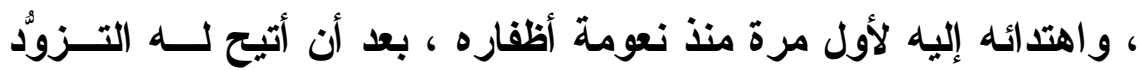
بالعلم الغزير من فقه ومتون وشروح وحواشٍ (1) . ويؤكد الأستاذ أحمد مصطفى حافظ مـــا لهـــذه القتــرة - علــى وجازتها - من أثر كبير فى بناء شـاعريته ، وصقل موهبته ، وكيـف أنّ الشاعر نفسه قد لحظ ذلك .. حيث يقول " وقد كان يعزو ( أى الثــاعر)

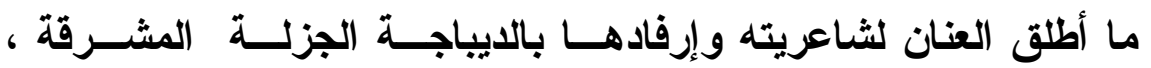
والأصالة اللغوية إلى تللك الفترة - فترة دراسته بالأزهر - رغم قصرها

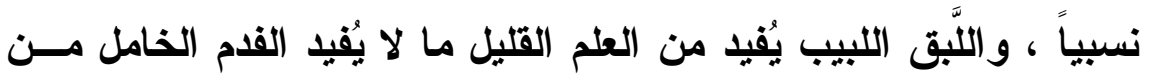

$$
\text { العلم الغزير فى السنوات المتطاولة " (؟). }
$$

ومن بواكير شعر الشـاعر فى تلك الفترة قوله من قصـيدة إلـى

$$
\text { ذات الله العلية : }
$$

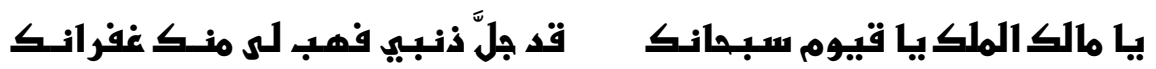

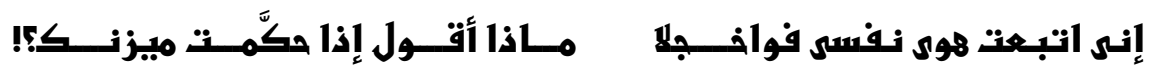

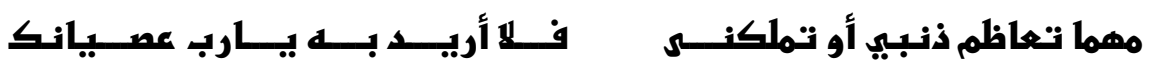

(' ) شعراء ودواوين - أحمد مصطفى حافظ صـ Y Y Y - ط الهيئة المصرية العامة للكتاب ط . 199 .

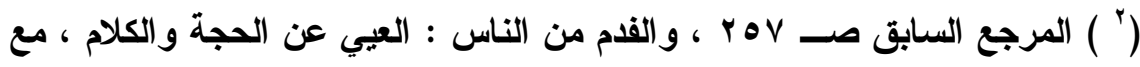

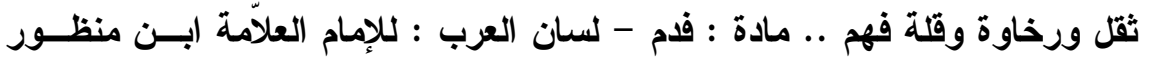

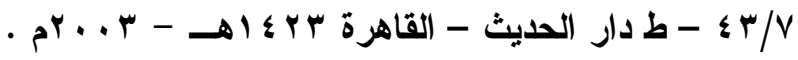




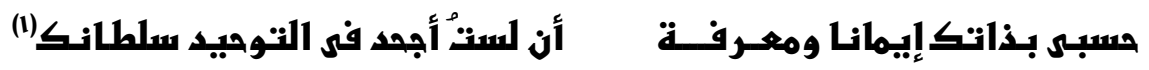
ومن ذلك أيضاً قوله فى مدح خير الورى ، ومناجــاة شخصــه

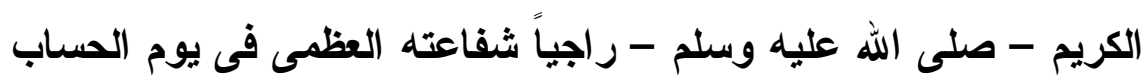
، متمنياً أن يحظى بالمثول فى ساحة مسجده الثريف : بالتجلى فى ثـــاء عطر جاعنا القرآن يُطرى أحمــــا ما لنا فعل حمبــــ الأثر يا شفيع الخلق إن جئنا غدا أو تغنى بلبل فى السحر صلوات الله ما طير شـــــــا نور(طه) قبل فوت الأجل هل لعينى يا حبيبي أن ترى - ائ

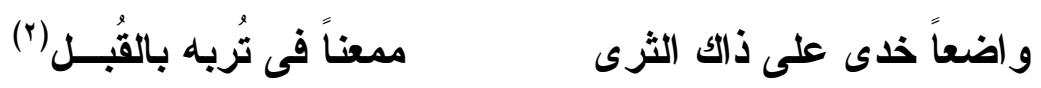
والأى يطل بنظره فى شعر محمد فضل إسماعيل يبــدو لــه أن الشاعر شمولي الفكرة ... حيث تعددت اتجاهات شــره بــين الشــعر الاينى - ذلك الذى أبدع من خلاله قصائد عالية القيمة تعـــ ابتهــالات

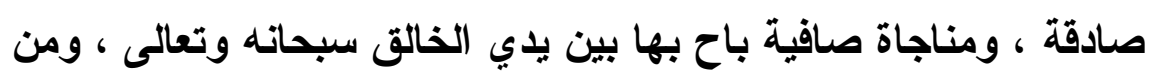
ذلك قوله :
وتعلم كل خــافية وهمــــسى
إلهى أنت تعلم ما بنفسى
وكيف عليه أُصبح ثم أُمسـى
وتعلم أن إيمانى قــــوي
ورض نفسى على أدب التأسى له
فصنُ عن كل مخلوق إبائى

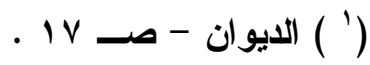

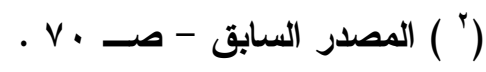


لأهو ائى ففى الأهو اءع بؤســى

إذا ما عشت أو جاورت رمسى

ولا لسو الك قد طأطأت رأســى (')

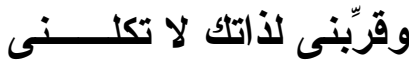

عزيز أنت فاجعنى عزيزاً

وله أيضاً أشعار شريفه سامية استمدت شرفها ، ونالت قــرها

وسموَّها ممن تتحدث عنه - وهو خير الورى سيدنا محمـــ صــلى الله

عليه وسلم فى كلمات عذبة ، وعبار ات رقيقة ولبنات شفافة .

ومن ذلك قوله فى رحاب هذا المقام السامى مُصوراً تقصيره عن

الإيفاء به، وبصاحبه الكريم صلى الله عليه وسلم .. مهما ؤهـبـ مـنـ

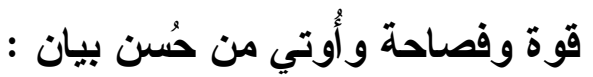

يا روض حدِّث عن الريحان والزهر وانشر أريجك بين الفجر والسحر

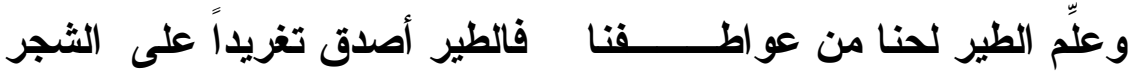
لعل فى طوقها التعبير عن مهــج تودُّ لو أفصحت عن طيّب الأثــــر إذ ليس فى عالم الألفاظ مُتســــع لما أحاول من قصد ومــن وطــر

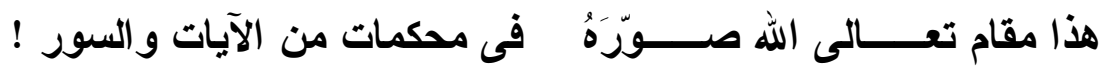

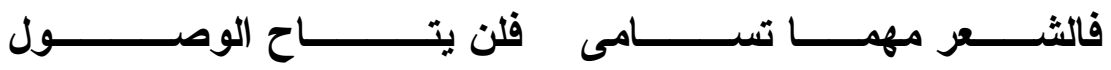

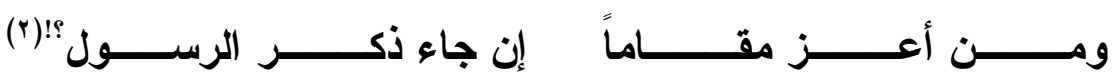

(' ) الديوان صـ V الـ والرمس : القبر ، والجمع : أرماس ، ورموس - لسان العرب - مادة رمس - \& / /

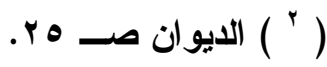


ولعل هذه النماذج وغير ها مما يسير فى نفس مضمونها هى مــا

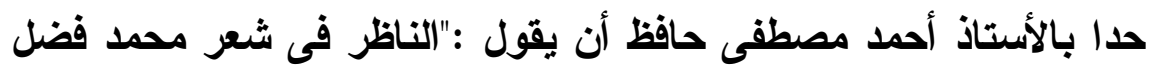

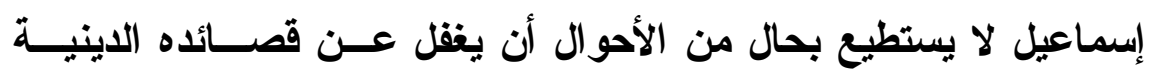

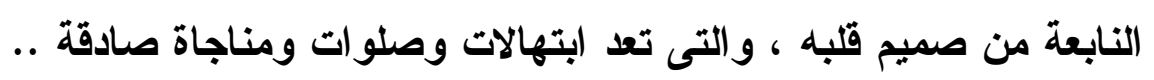

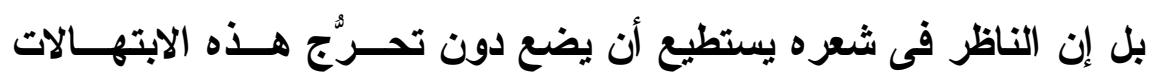

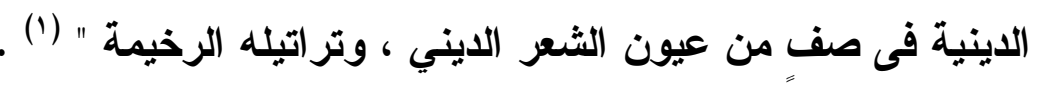

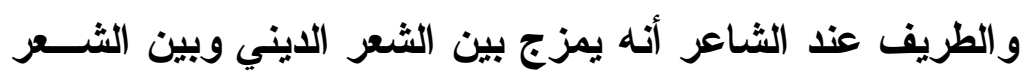

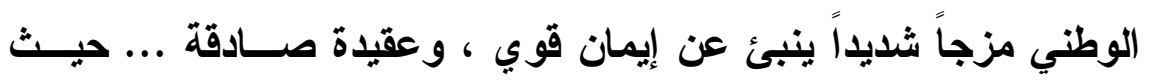

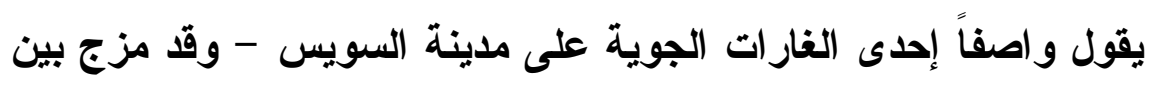
الدين و الوطن :

كانت مخابئنا التقوى نلوذ بها خير المخابئ ما بالدين نبنيــــــها فالاين حصنُ قويُ فى جوانبه ما ينسف الأرض والانيا وما فيها

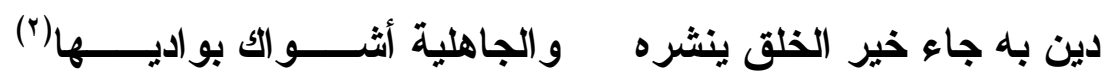

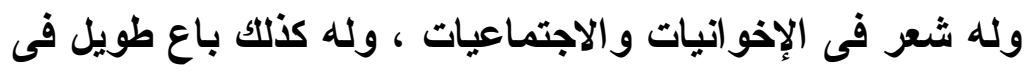

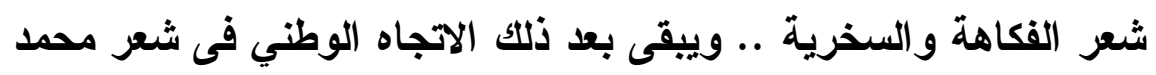

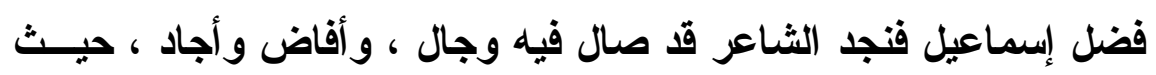

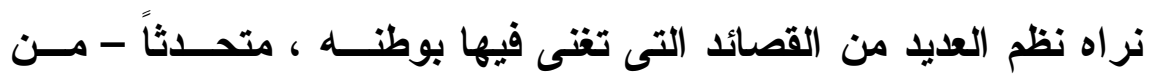

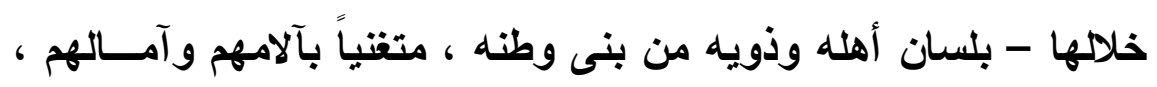

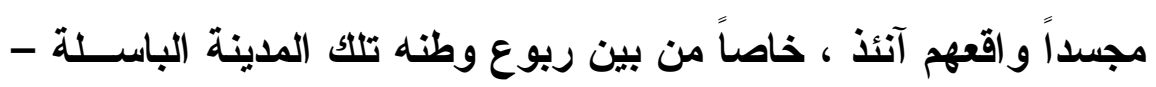

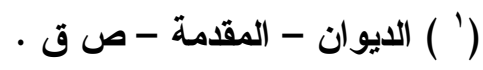

$$
\begin{aligned}
& \text { (' (المصدر السابق - والموضع نفسه. }
\end{aligned}
$$


مدينة السويس التى نثنأ فيها وشبَّ ، ونما وترعرعــت موهبتـهـ علـى

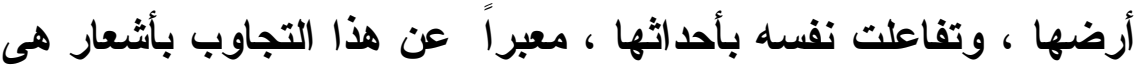
من القوة و الجودة والصدق بمكان ! ، حيث كانت بحق ترجماناً صادقاً ، ومر آة مصورة لما يحدث فى تلك الربوع وما كان يقوم به أبناء الــوطن من بطولات نادرة ضد المستعمر وأذنابه من الخونة الغادرين ... وقا كان شعر محمد فضل إسماعيل -فى مجموعـه- موضــع تقدير النقاد ، ومحل إعجابهم - يبدو ذلك من خلا كلام الدكتور /مختار

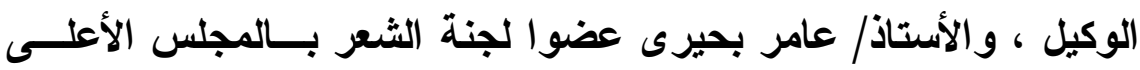

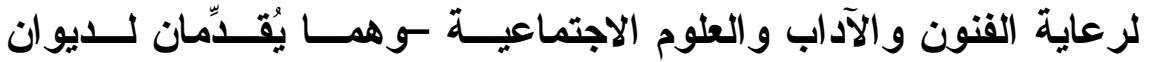

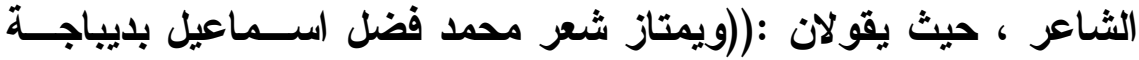

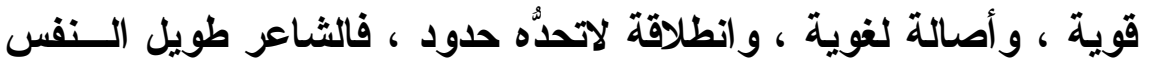

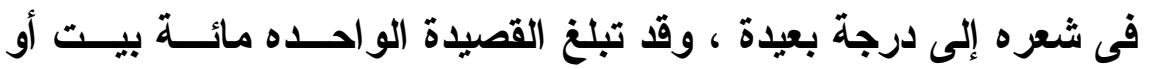

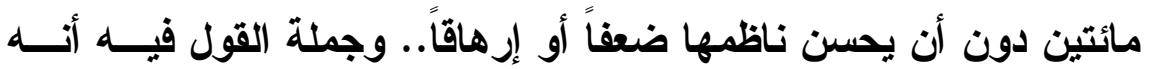

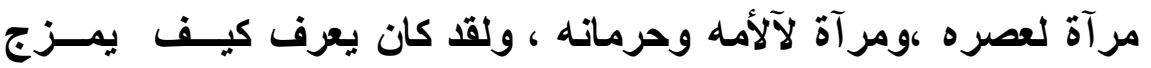

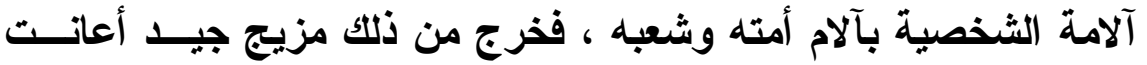
عليه ديباجته القوية ،وحصيلته الطيبة من الألفاظ و الصــور البيانيــة ، وكان شأنه إذا نظم شان الناسج على المنو ال يُحرك خيوطه يمنة ويسرة النها

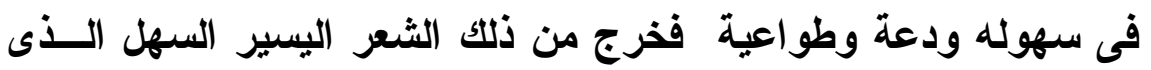

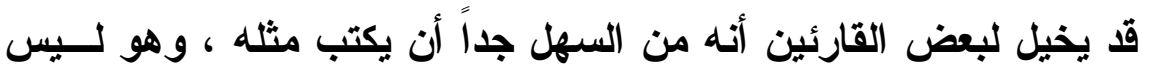
كذلك فى واقع الأمر ، ولكنه شعر أخرجته إلى السطور حاســة معبِّرة

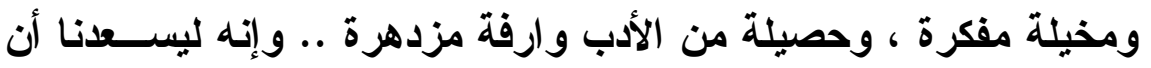

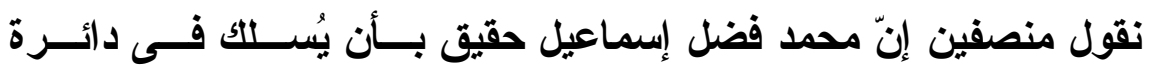


يتارجح فيها ما بين حافظ إبراهيم وبين عبد الحميد الديب ، فهـو يَعـــوُ

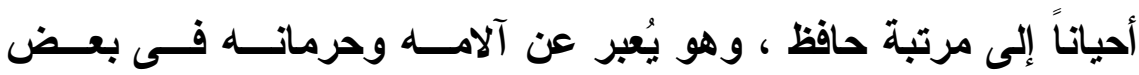

الأحايين الأخرى تعبير عبد الحميد الايب "(1).

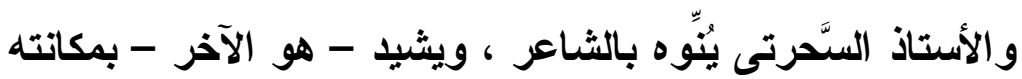

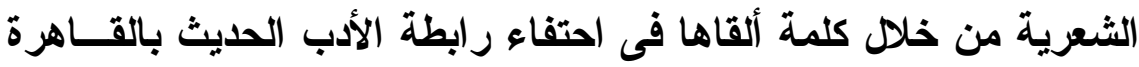
بذكرى محمد فضل إسماعيل السنوية ، حيث يقول :" إن الثاعر محمـــ

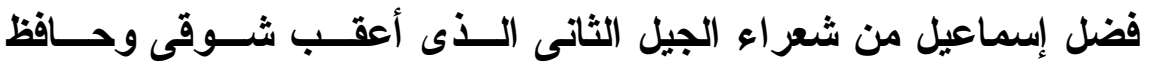

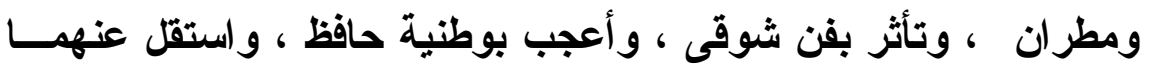

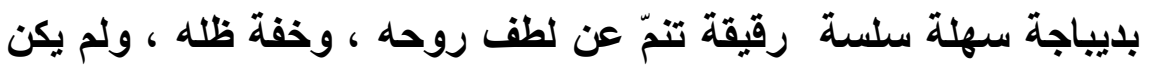

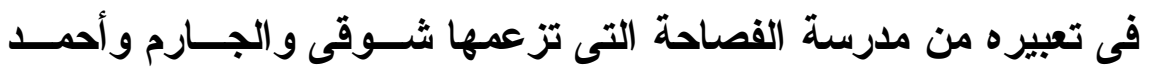
محرم ، ولكنه كان من مدرسة البساطة التعبيرية التى ضــــت أمثـــال: محمود عماد ، وطاهر الجيلاوى ، وعثمان حلمى ، ومحمــود جبـر ..

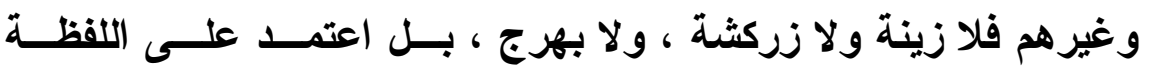

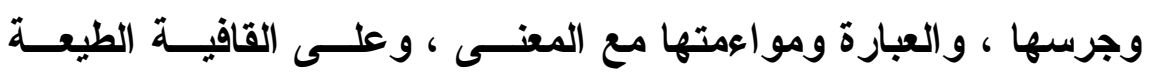

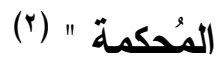

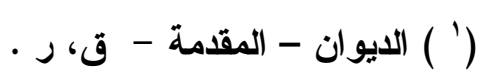

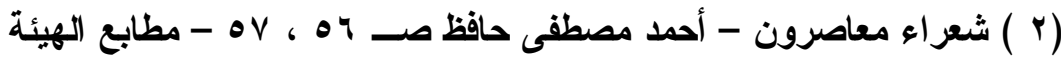

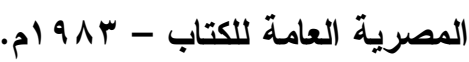


$-\Delta \Delta r-$ 


\section{فصل الدراسة الأوحد}

الأبعاد الغكرية ، والآناق الهوضوعية الهوايه

الشعر الوطنية عند الشاعر

ويتضمن مبحثين :

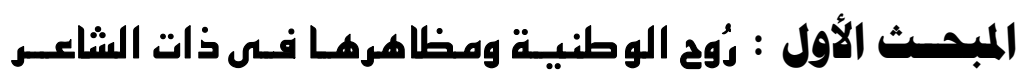

وكيانه ، وأدبه .

المبحث الثانى : الأبعاد الفكرية ، والآفاق الهوضوعية لشعر ، الشعر

الوطنية لدى الشاعر ·

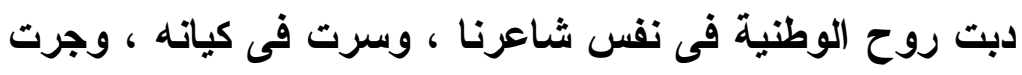

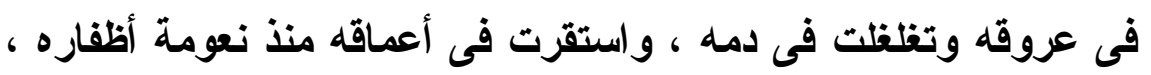

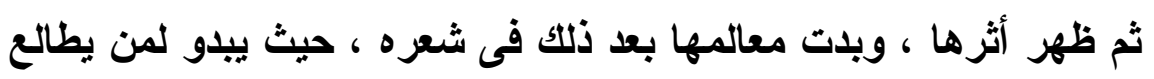

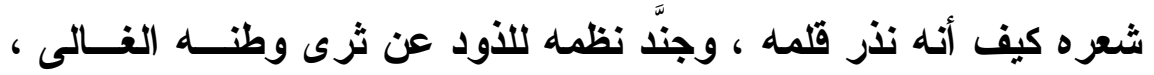

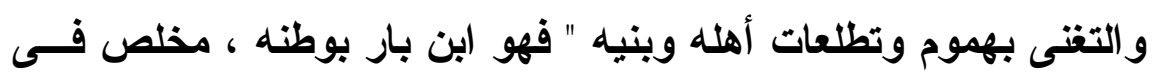
حُبه إياه ..كم كان يرجو ويأمل فى أن يحيا بنو وطنه حياة كريمة ملؤها هانها

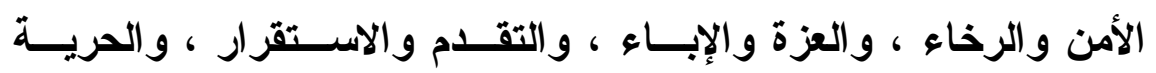

والاستقلال ، مهما كلفه ذلك المشقات وجرّ عليه الويلات .

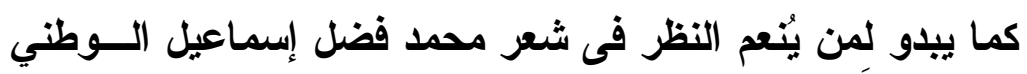

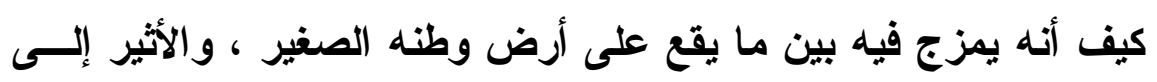

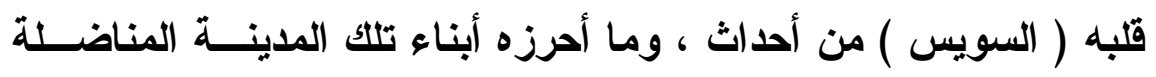

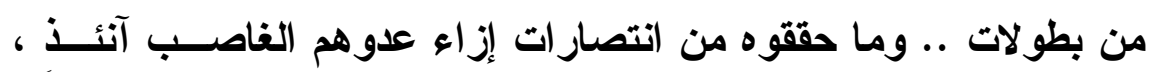

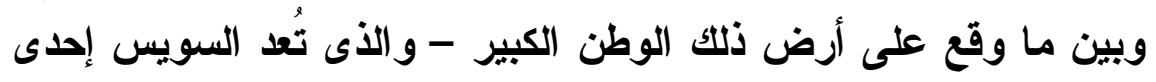
ربوعه الغالية .. إنها مصر الحبيبة من أحداث خالدة ، وبطولات مجيدة 


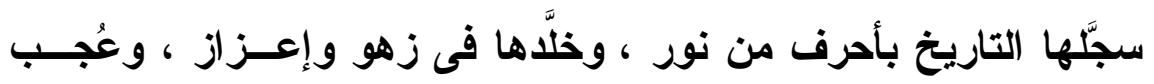

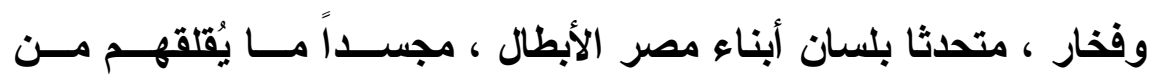

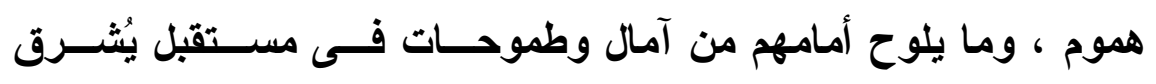

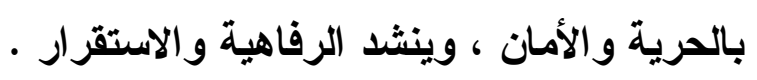

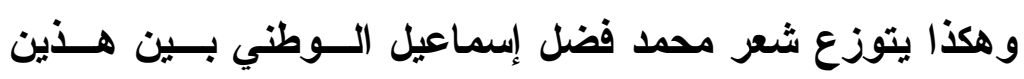

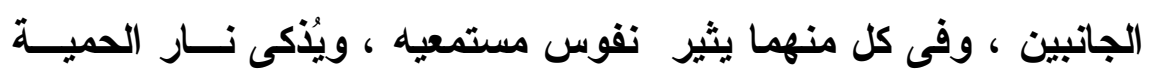

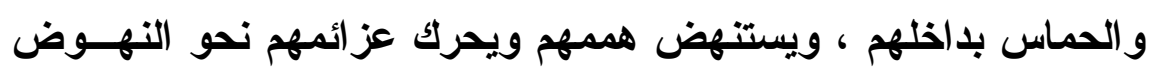

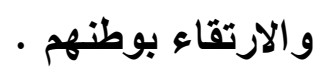

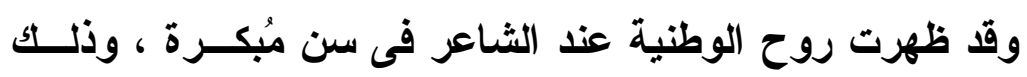

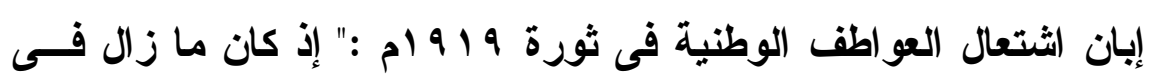

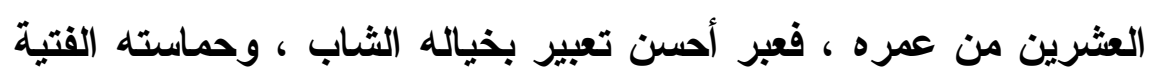

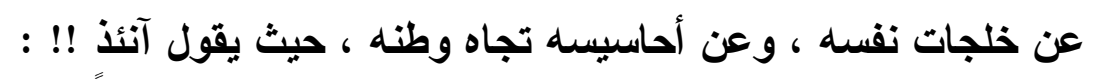

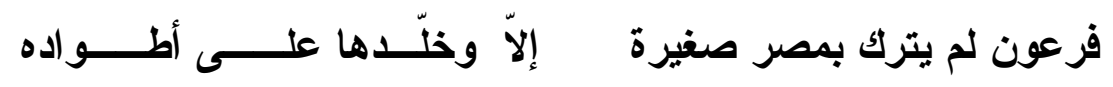

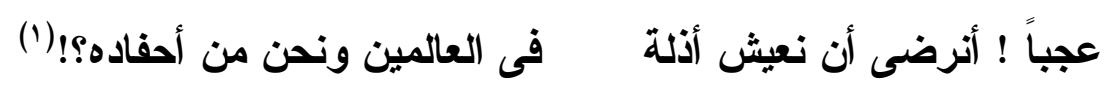

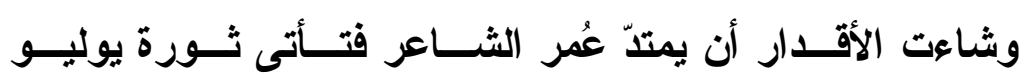

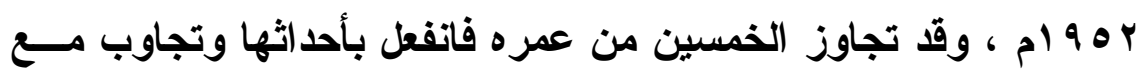

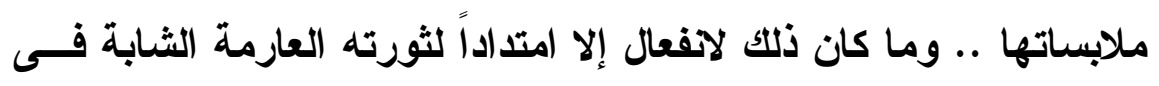

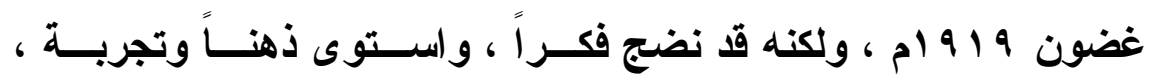

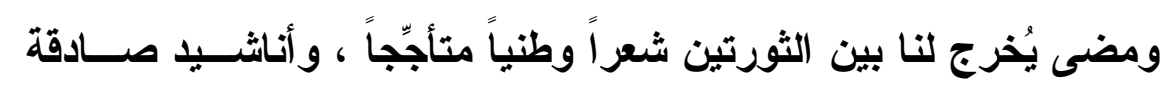

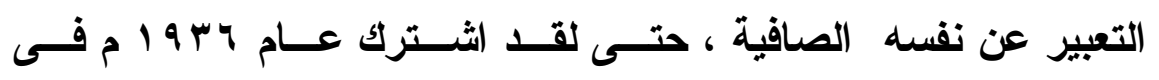

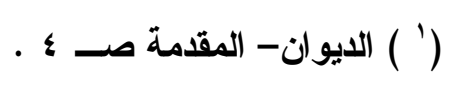


المسابقة العامة التى أقامتها الدولة لإعداد نشيد قومى ، وخرج من هذه

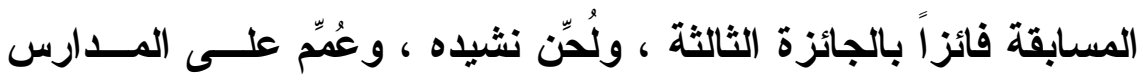
وغيرها من الهيئات الرسمية ، وفيه يقول مخاطباً نيل مصر :؟ إنه وحي من السحر المبين فاجر يـا نيلُ بواديك الأميــــن ينحنى فى جاتبيــه النيرِّان نوره فى الآَّر وضاح الجبين طاولوا ملتك الثــــــــــبـ

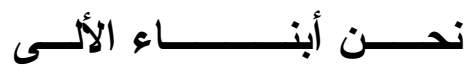

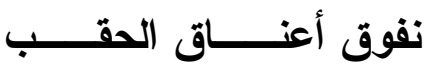

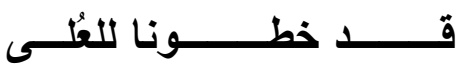
أنت للأوطان جاه أي جاه !! - ( واسقتا يا نيل من نبع الحياة من شباب أو كهول أو حسان يستميث الشعب حُبا فى علاه

نحن أبناء الألى (1)

وقد ظلَّ - رحمه الله - وفيا للسويس بعد عدوان 97 1 19 وحتى آخر نفس فى عمره ، حيث مكث بها- رغم شيخوخة الســبعينات لمـــه تزيد على العام يسهم بقصائده الحماسية فى إذكاء الشعور الوطني فـى مرحلتي الصمود والردع بروح فتية لا تعرف الكلل ، ولا سبيل لها إلـى لـى الملل.. ومن شعره فى هذه القترة :

بل بالمدافـــع للأمســــام تقــــدم هو كالسيّعـيرعنـى مهاد جهنم لا القدس فى ظل المسيح ومريم
بلســـــاتك العربـــــى لا تتكلم واجعل لاستر ائيــــلـل قبراً هاهنـا فالتيهُ و الأرضُ الخرابُ ديارهم

$$
\text { ( ' ( الديوان- المقدمة صـ ف . ( ) }
$$




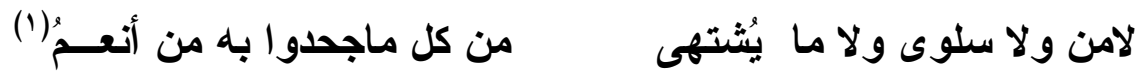
ولم يكتف شاعرنا بأن ينذر شعره ، ويُسخرِ نظمه فـى صـالح

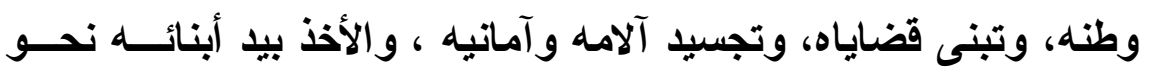

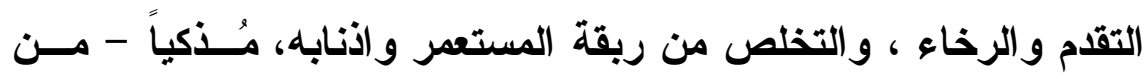
خلا أثنعاره الوطنيــة المتقــــة ، وأناثــيده الحماســية روح الحميــة والحماس فى نفوس بنى وطنه ، ومحركاً بداخلهم مشاعر الإباء والأفة

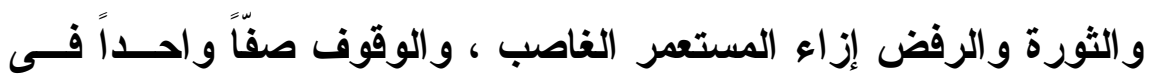
وجهه، والعمل على طرده من أرضهه ، وتطهير ثراهُ الغالى من رجسه، ودنسة.

لم يكتف الشاعر أن يجسد تللتك المضامين الوطنية فى شــره ، و إنما راح يبرز تلك الروح الوطنية الثائرة ، ويجسدها أيضاً في كتاباتــهـ

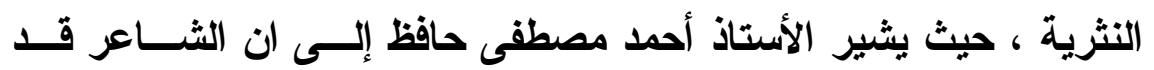
أصدر جريدة تسمى : "الثغز الثرقى " بالسويس.. وقد صدَّر العدد الأول منها بتلك المقدمه التى تفيض بمشاعر الحب والفداء ، والتقدير والثناء

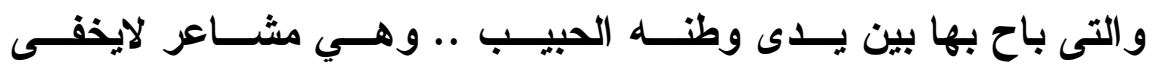
صدقها،ولا يُّكر سموها، حيث يقف الشاعر إزاء وطنه مناجياً ومفضـياً بما يكنه نحوه

$$
\text { ( ' ( ' (الديوان - المقدمة - صــ ( ) }
$$


من مشاعر صادقة،وأحاسيس بالغة، يقول :

" أقت اليوم أمام جلالك أتغنى على دوحة مجـــك الرائع،أتقــدم

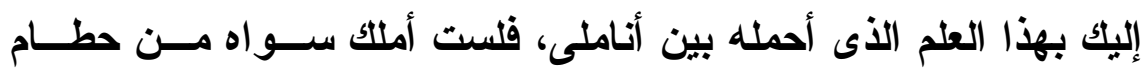

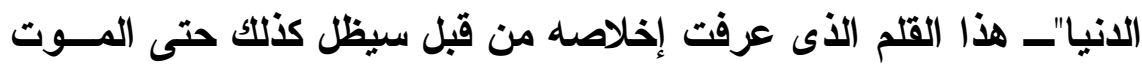

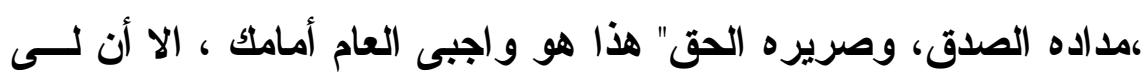

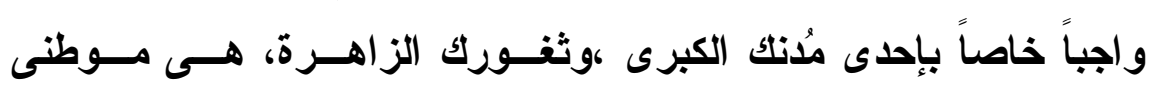
(السويس. (1)

وقد التزم الثـاعر بعهده الأى قطعه على نفسه، فلم يتوان عـن

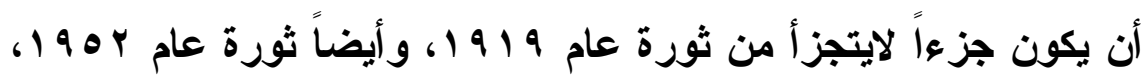

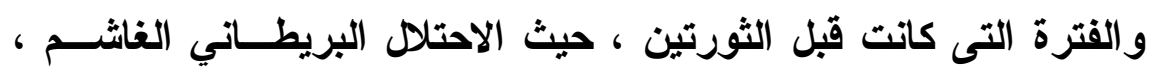
و الفترة التى وقعت بين الثورتين ".

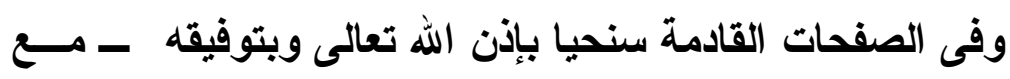

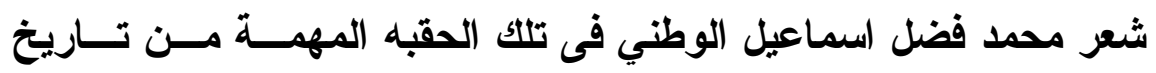

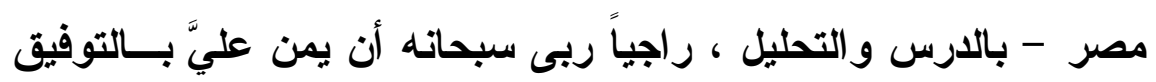

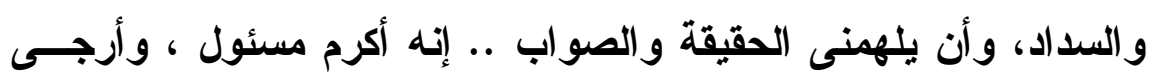

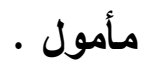


المبحث الثانى: الأبعاد الفكرية ، والآفاق الموضــوعية لثــر

الوطنيه عند الثاعر. - (الثاع.

الثناعر محمد فضل إسماعيل - كما تنطق أثعاره- هـو واحسـ من شعراء الوطنية البارزين فى عصره،الغيورين على وطنه ،المخلصين

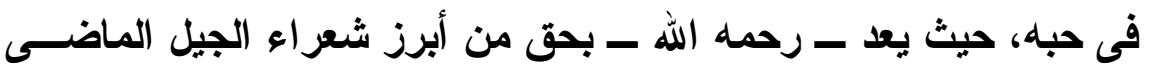
الأى ظهر منذ أوائل العشرينات ،والأى اضطلع بحمل الأماته بعد أن خلا الثعر من فرسانه، فى أوئل الثلاثينات وما تلاها.

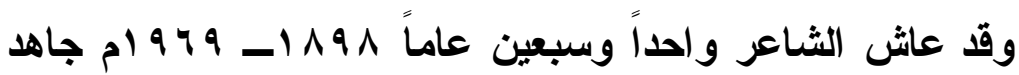

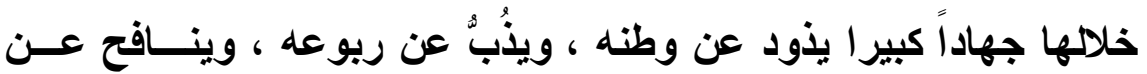

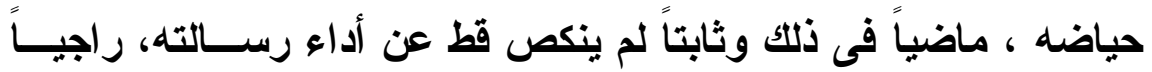

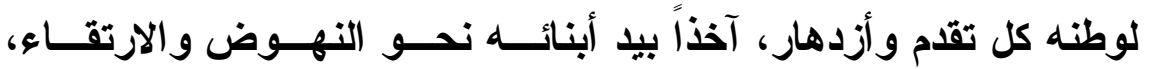
و الحريه و الاستقلال بما يشيره فيهم من معانى التضحيه و الولاء ، و البذل و القداء: " فالثعر كان وما يزال يثير الثجاعه ،ويذكى الحماس، ويجسم

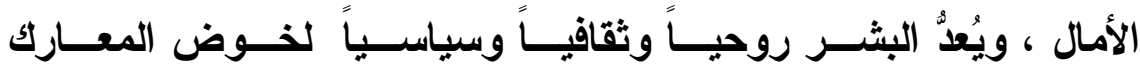

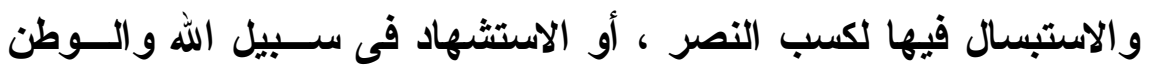
و والمبدأ و العقيدة "((1) .

وسينطلق حديثى عن شعر الوطنية عند محمد فضـل إبـــاعيل

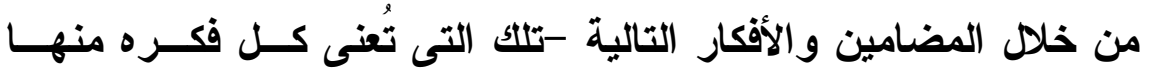
بمعالجة موضوع من موضوعات شعر الوطنيه عند الثاعر .

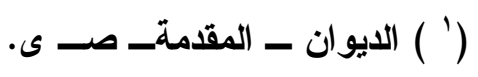


أولاً ــ التظنى بحب الوطن ، و التنويه بأمجاده ، و الإثـــادة بمـــا تتو افر عليه طبيعته من مجالى السحر والجمال، والمظاهر النادرة المثثال فى الحُسن و البهاء .

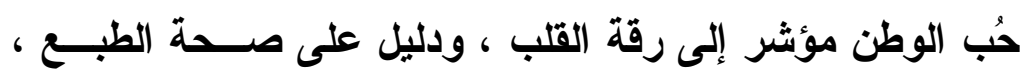

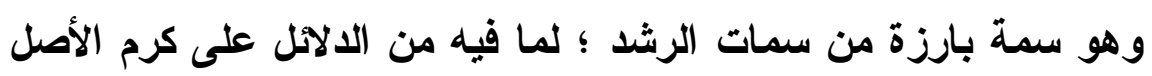

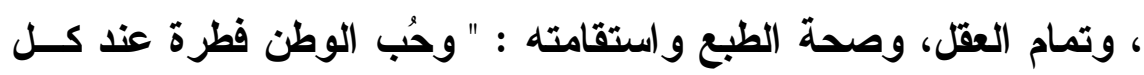

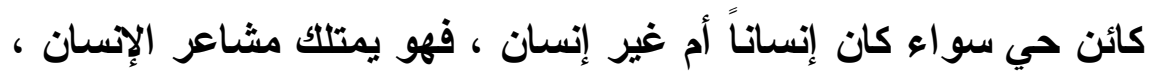

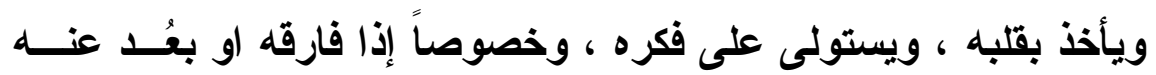

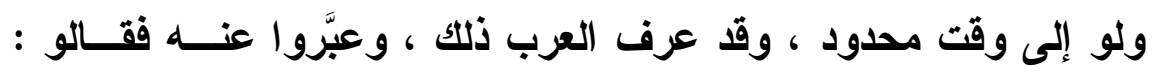

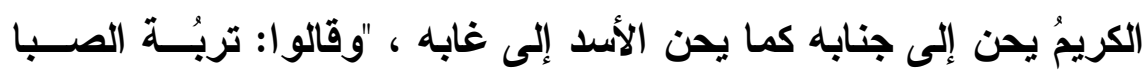

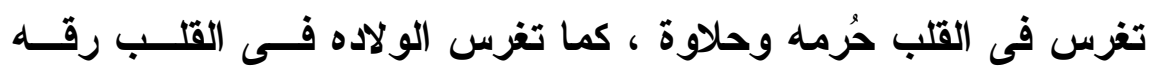

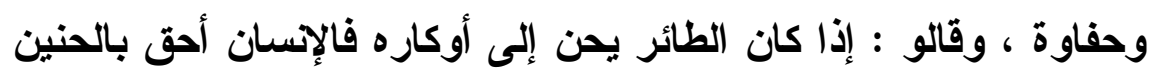

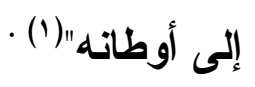

وشاعرنا كان ممن صحت طباعهم ، واستقامت نفوسهم فــراح يتغتى

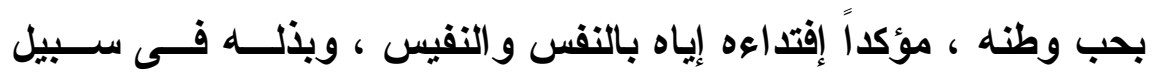

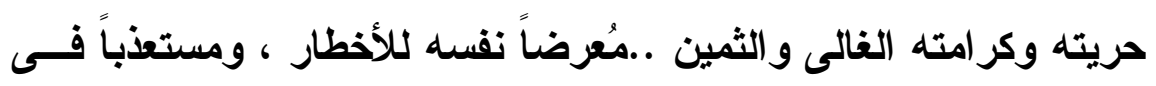

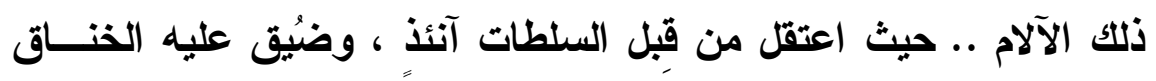
حتى يخرس صوته ، وتخبو جذوة الحماس المتقدة فى وجدانه ، لاسيما

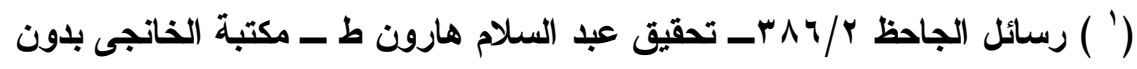

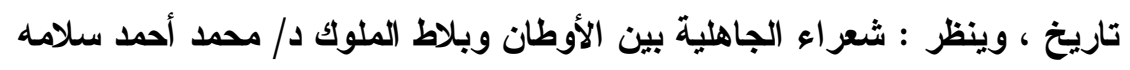

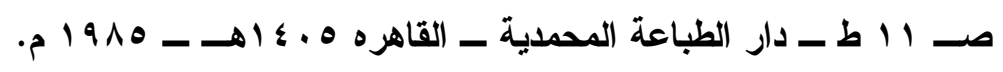


بعد أن اشتتدت وطأته على المستعمر وأذنابه الخائنين بنقداته اللاذعــة ، و انتقادته الجريئة لسياستهم الجائرة ، وقيادتهم الطائشة . ومن شعره فى التغنى بحب وطنه قوله ـ ـوقد وقف أمام جلاله و هيبتــهـ

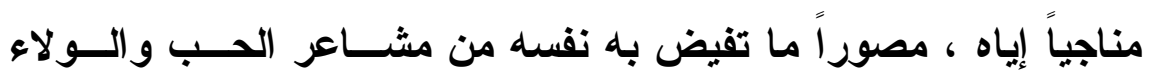

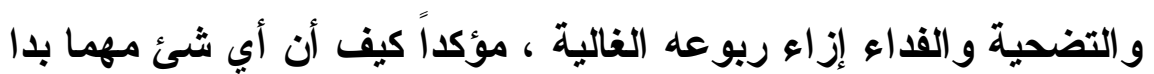

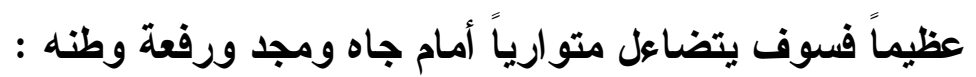
وطنـى سلمت فعن حمــاك أقاتل ويمهجتـى أفديك لـست أجامل !! فأمسام جاهك كـل جاه يمدسى وأمسـام مجدك كـل شــئ زائل (1)

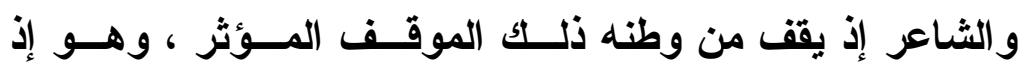
يُعبر إزاءه بائحاً بتلك المشاعر الفياضة التى يؤكد صدقها فهو يقرر أنــهـ يجد ذلك قليلا إزاء ما عليه من حق وواجب نحو وطنه الغالى ذى المجد

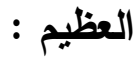

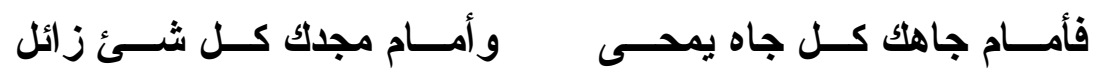

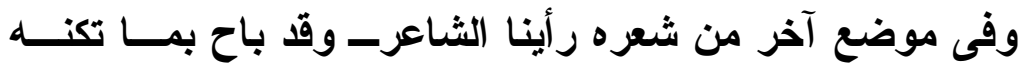
نفسه إزاء وطنه من مشاعر الحب و الفذاء الفياضة الصـادقة ، حيــث

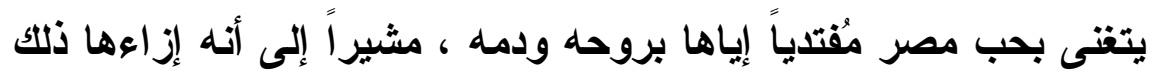

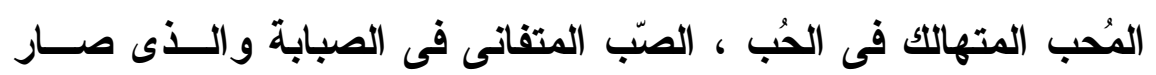

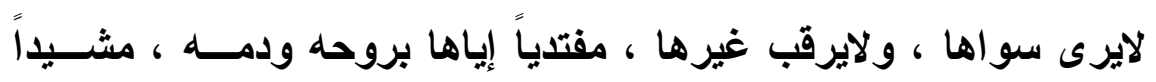

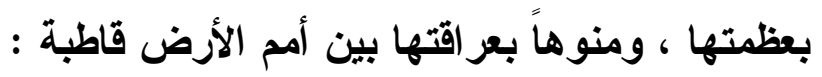




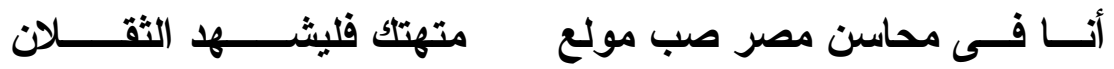

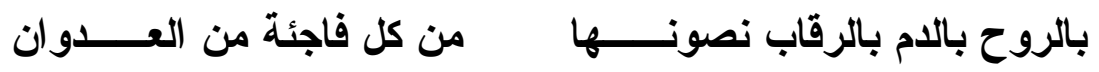

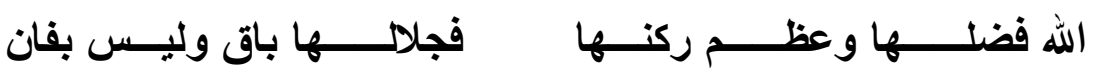
خرت ملوك الأرض حول رحابــها من خثية صرعى إلى الأذقان (1) وهو يمعن ـ كما نرى ـ من خلا كلماته وتعـابيره هنــا فــى

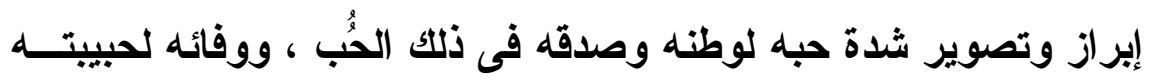

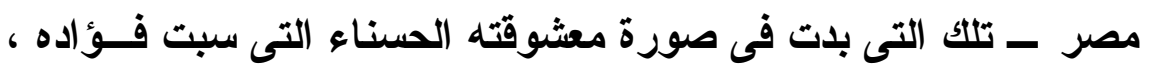

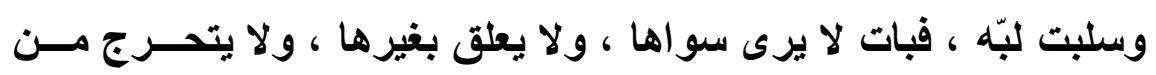

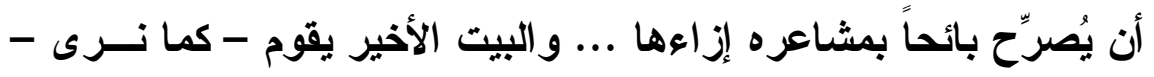

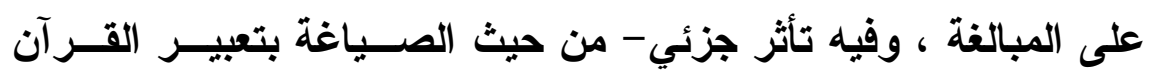

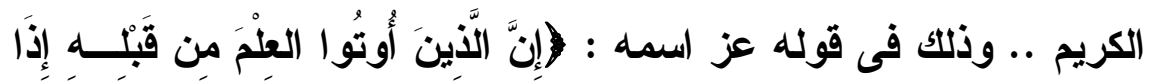

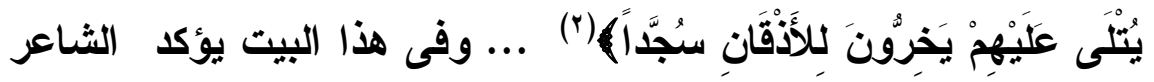

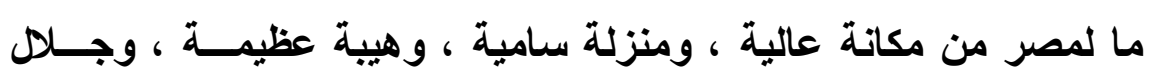

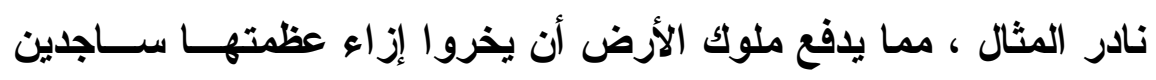

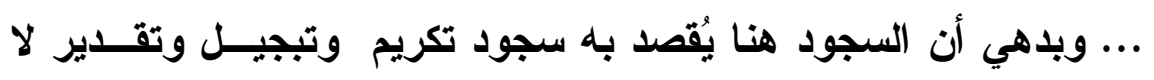

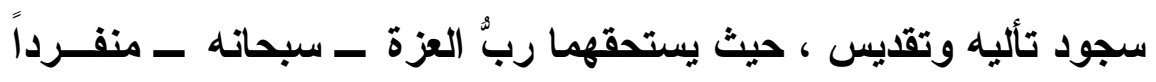

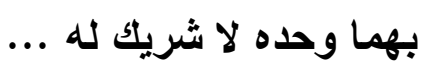

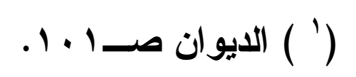

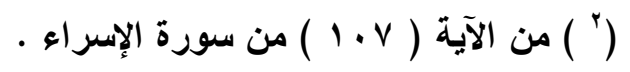


هذا عن الوطن فى مفهومه الكبير ونطاقه الواسع .. أمسـا عـن ملاعب الصبا ومراتع الثباب ، ومواطن الذكريات الأولى لاى الثـــاعر لهر حيث وطنه ، ومسرح ذكرياته الذى هو جزء من أرض مصر الحبيبــة ـ

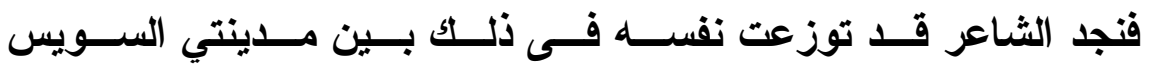

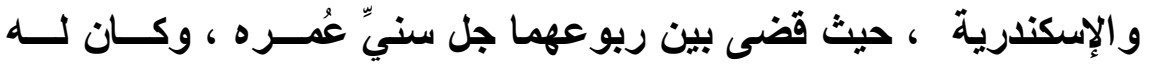

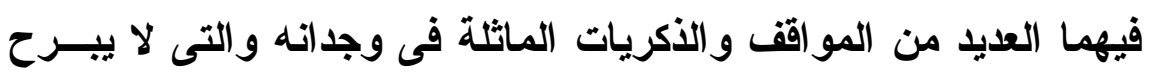
يتذكرها ، ولا ينفك عن التظفى بها ، وتصوير شدة الثوق والحنين إليها

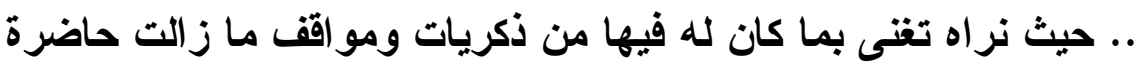

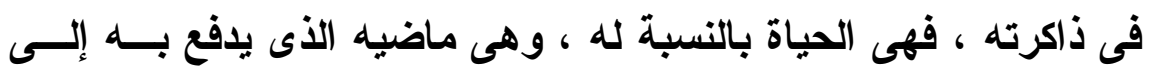

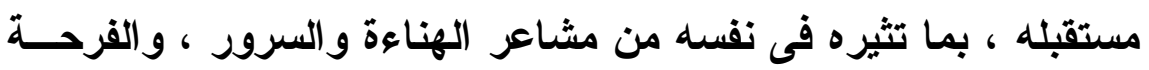

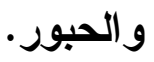

فها هو ذا - وبعد أن بَعُ عن مراتع صباه ، وملاعـب لهــوه

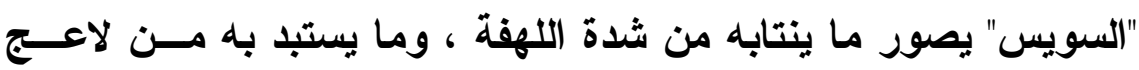

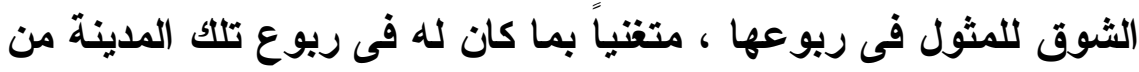

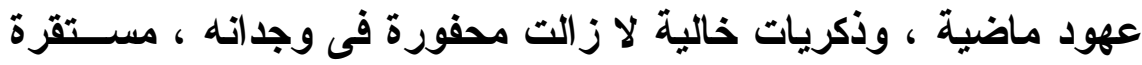

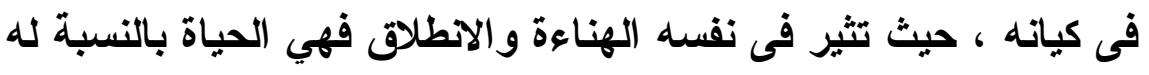

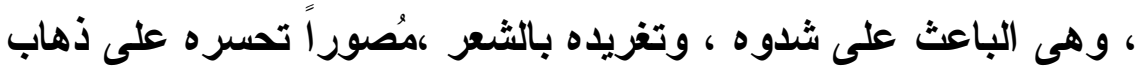

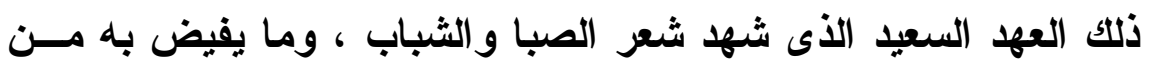

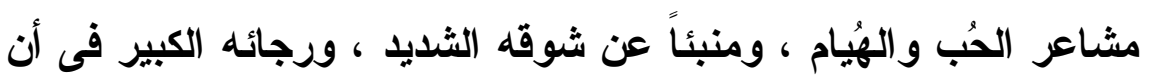
يعود إليه ثانية.. حيث يقول :

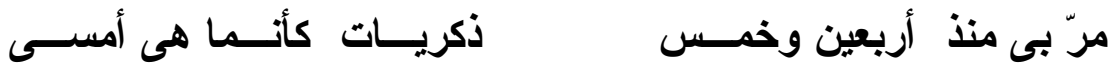
كان فيها الخيــال يملأ حسى فاتركونى إذن أعـود لنفسـى 
هاهنا فى السويس كاتت حياتى

و الهوى و الثــباب من نــدواتى

أين شعر الصبا وكيف التأسى؟!(1)
إنّ عهذ الثباب عهذ السويس مبعث الشعر فى فم النســــات فيهما كنت صاحب النظــرات

وتفيض تلك الأبيات - كما نرى - بما يستقز فى أعماق الشاعر

إزاء السويس ذلك الربع العزيز من الوطن الأمِّمصــر - مــن مشـــاعر

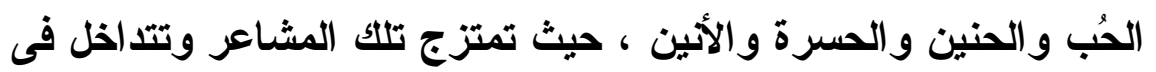
نفس الشاعر .. خلال تلك الفترة المعنية .. فهى فترة تستأهل التحسـر على ذهابها ، ومن ثم الحنين الجارف إليهـــا ... يبــدو ذلـــك التحســر والأسف من خلال تساؤل الثـاعر الأى يجسد ـ من خلاله ـ ـ ما شــابه

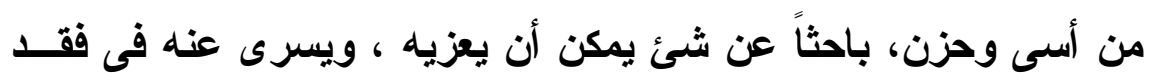

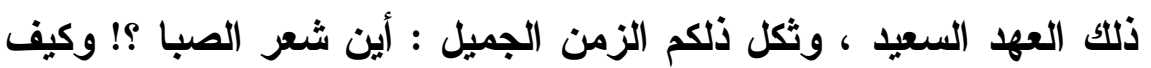
التأسىى ؟!.

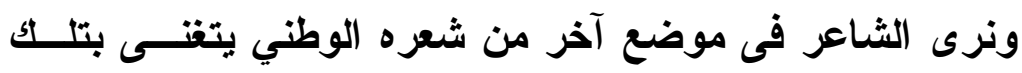

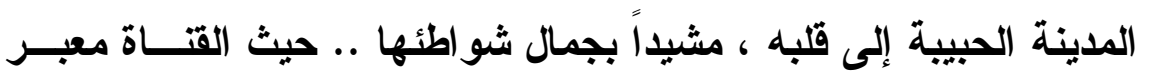

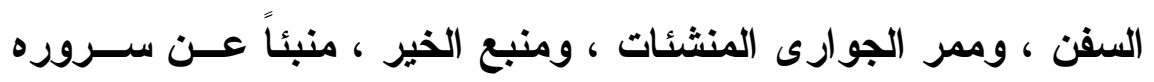

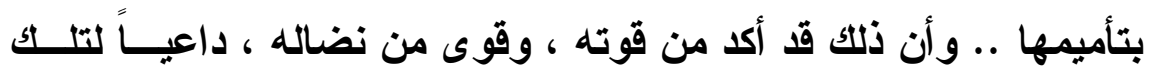

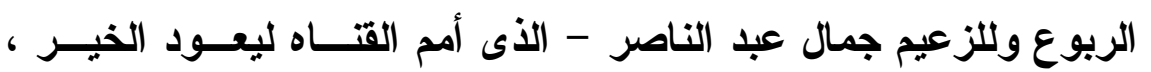

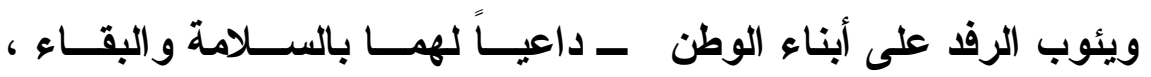
منوهابِما على أرض السويس من معالم القداسة ، ومظـــاهر الحضــــارة

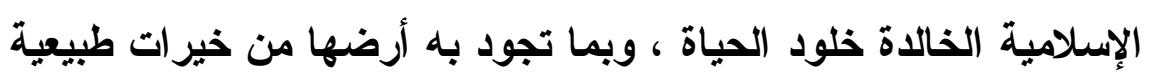


، وثروات معدنية من بترول وملاحة ، وما يستتبع ذلك من مصانع يعود

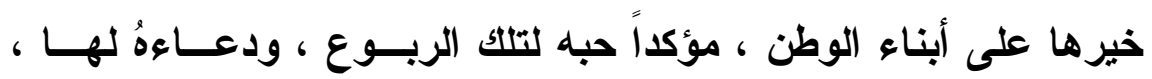
ولزعيمها بدوام السلامة والنماء .. لنستمع إلى الثاعر وهو يتغنى بتلك هول المعانى فى كلمات وتعابيز دالة موحية صبها فى قالب موسيقي تجديدي يأخذ شكل النشيا .. حيث يقول :

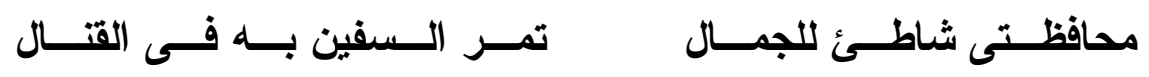

$$
\begin{aligned}
& \text { وتعلـــم أنـــى قــوى النضــال وتــأميـــهـ زاد مــن قـوتــى } \\
& \text { تعـيش الـسويسـس ويحيـا جمــال }
\end{aligned}
$$

بموســى الكليــم تتــادى العيون وأمجــــــاد خلاتـــها الــسنون تعـيش الـسويـس ويحيـا جمــال

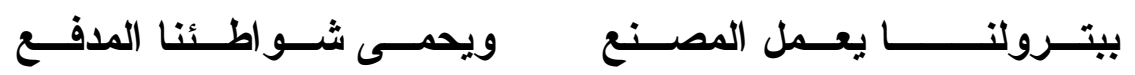

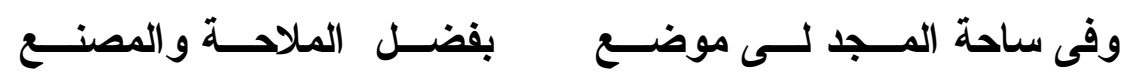
تعـيش الـسويسـس ويحـيا جمــال (1)

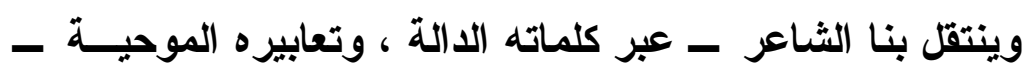
إلى الموطن الثانى الأثير إلى قلبه ، القريب من نفسه أيضاً ، حيث مدينة

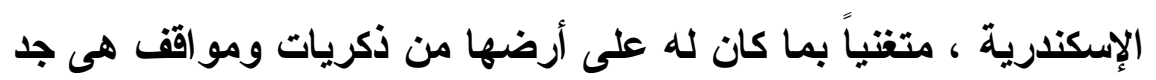
ماثلة فى وجدانه ، حاضرة فى خاطره ، لا تغيب قط عن مخيلته ... فها

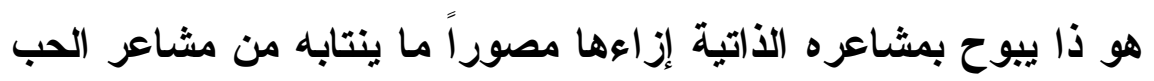
والحنين لاسيما بعد أن نأى عنها فأخذ الثوق منه مأخذه ، وناله من ألم

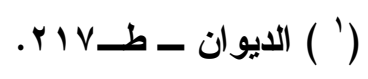




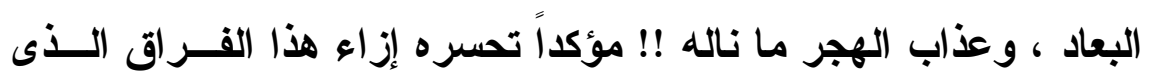

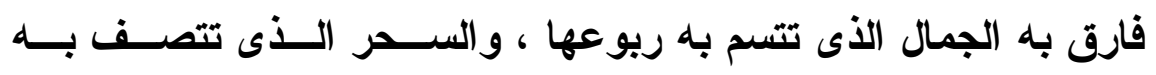

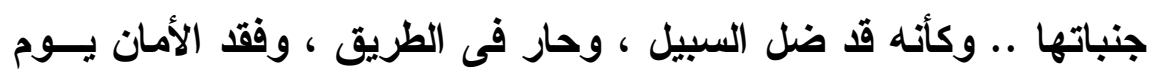

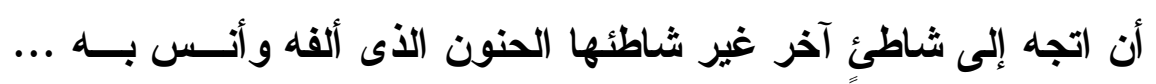
حيث يقول : انجه إن

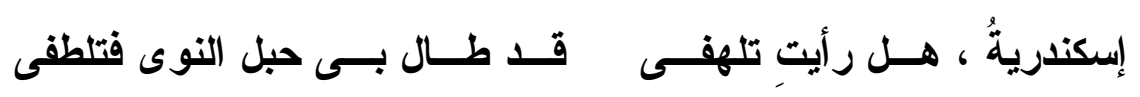

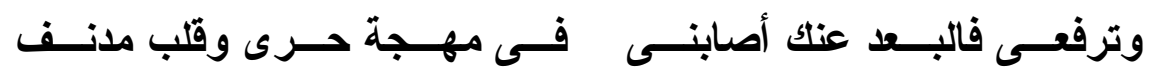

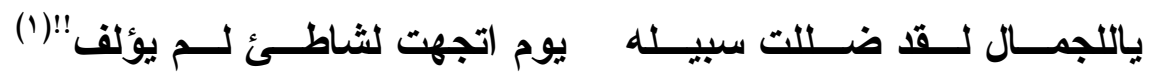

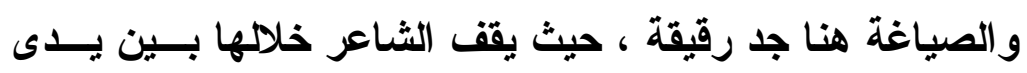

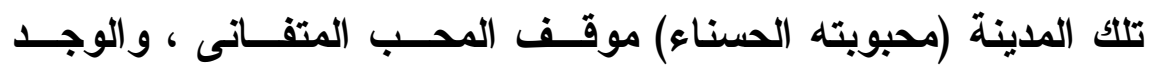

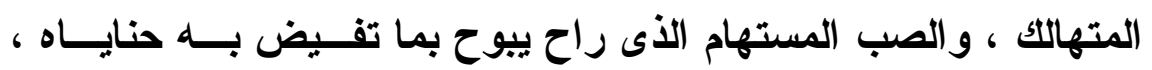

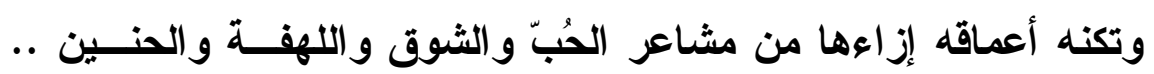
وهى مشاعر قد استبدت به ، وتملكته فصار لايقدر على الفكاك منهـ . . .

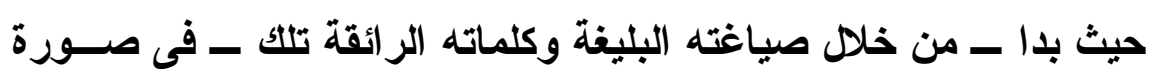

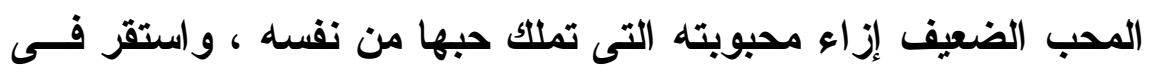

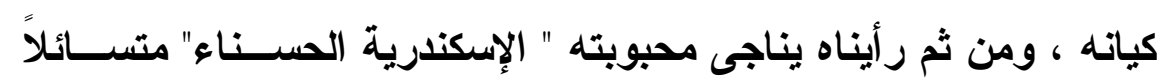
وراجياً ومستعطفاً :

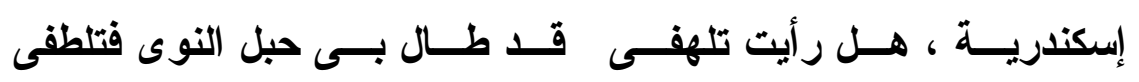
ويؤكد الثـاعر تلك المشاعر ذاتها إزاء محبويتــه الإســكندرية "الغادة " بقوله مستعطفاً إياها:

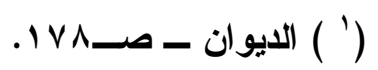




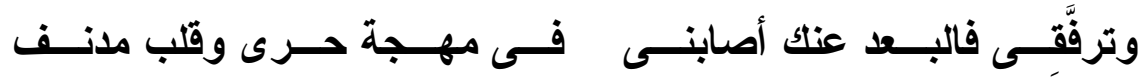

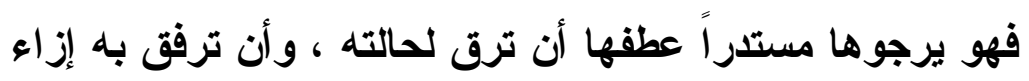

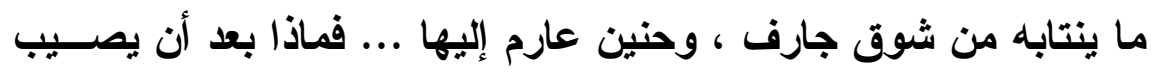

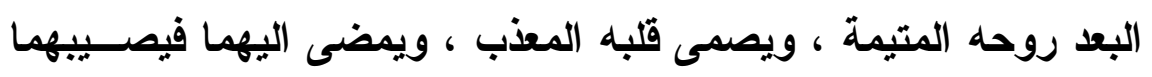

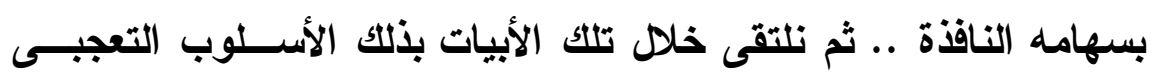

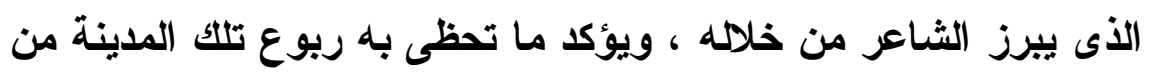

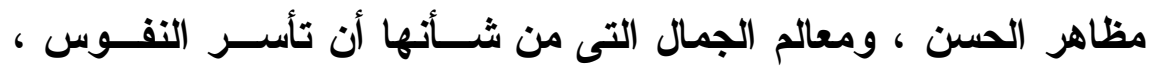

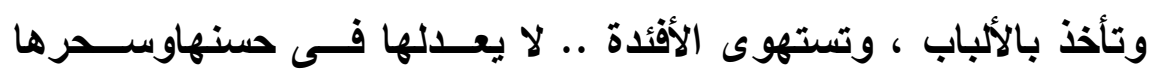
وبديع صنعها ربع آخر !! وهذا مادفع الثاعر أن يتغنى قائلاً :

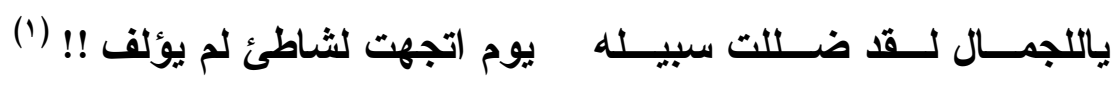
وهكذا يبدو الثـاعر ـ خلا مقطوعته الرقيقة تلك ــ بما تتـــوافر

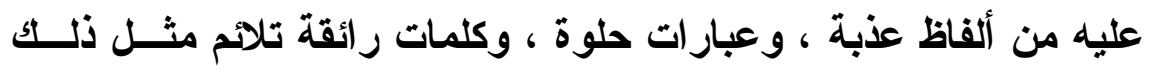

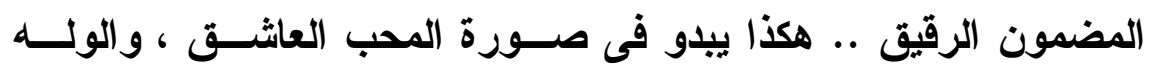

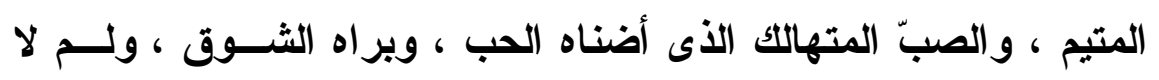

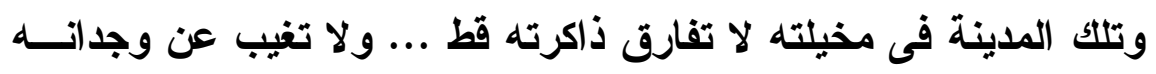
أبداً على نحو ما يبدو فى قوله:

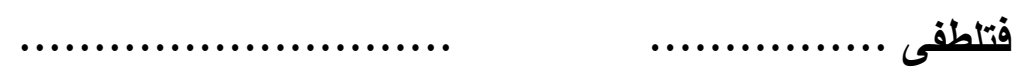

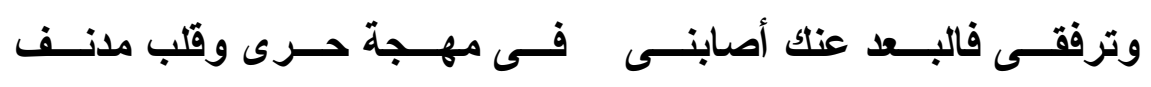

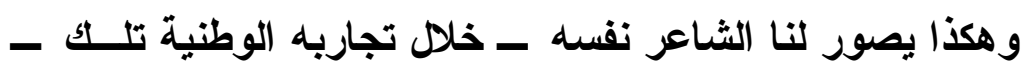

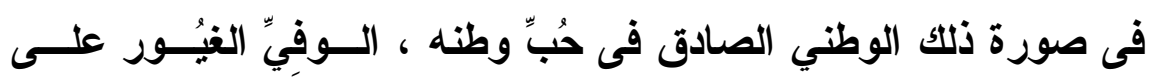

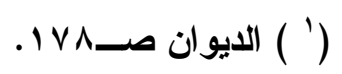


حرمته الذى يفتديه بالغالى و الثمين ، ويبذلُ فى سبيل بقائه عزيزاً كريما

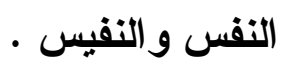

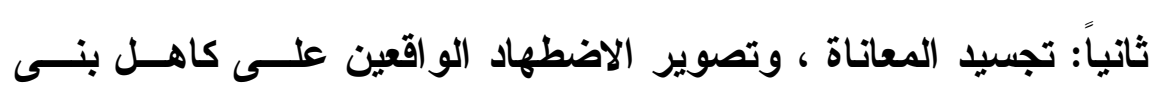

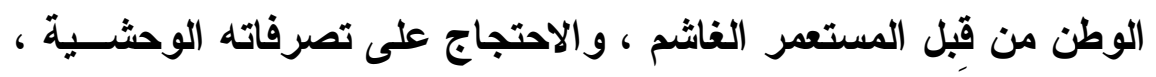
وممارساته الهمجية أنئذٍ.

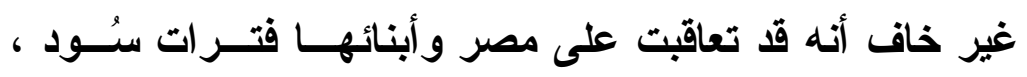

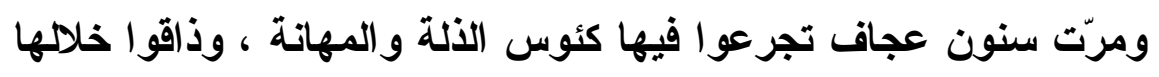

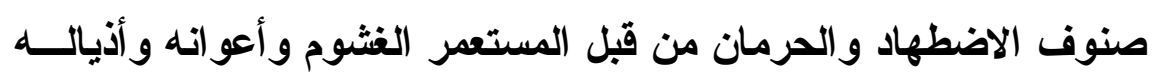

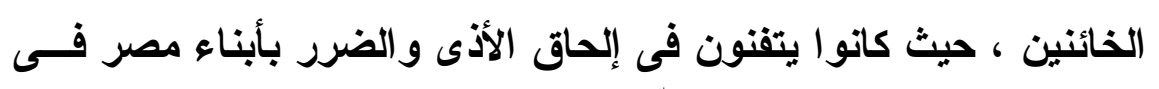

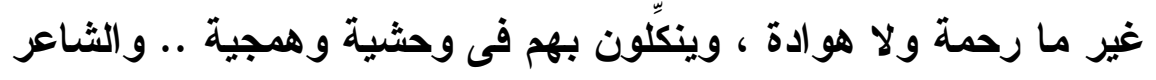

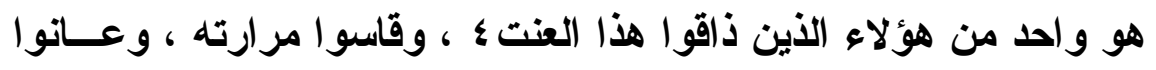

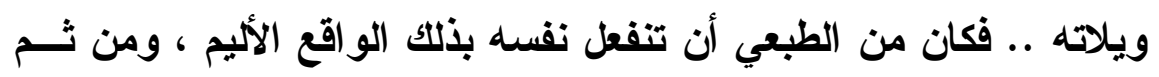

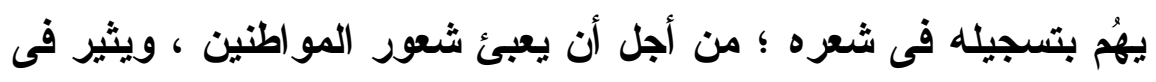

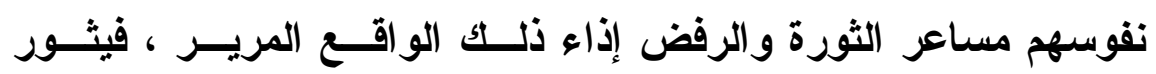

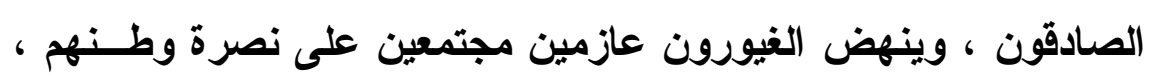

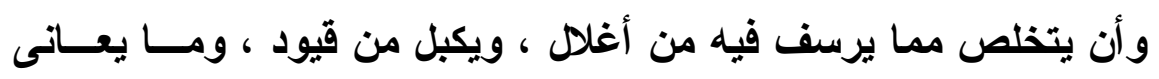

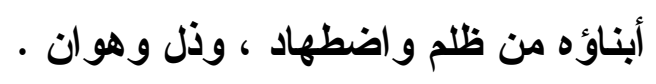

ومن ذلك قوله يُجسد فى شعره ما وقع على كاهل بنـــى وطنــهـ

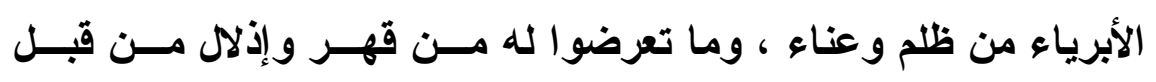

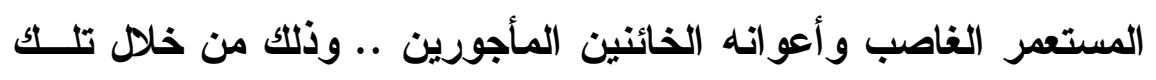

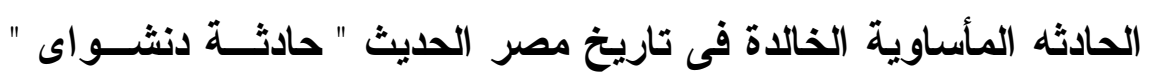

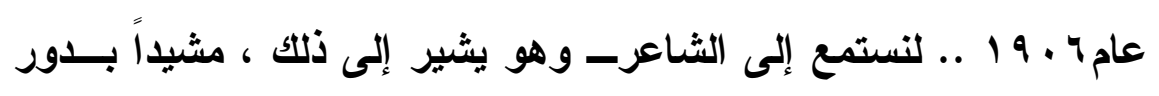


مصطفى كامل ـ أحد قادة الحركة الوطنية البارزين فى مصــر أنئــــ ،

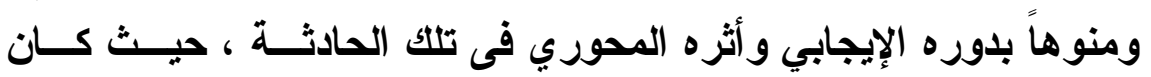
اللسان الذائد ، و الترجمان المعبر عن بنى وطنه فيما وقع عليهم خـلهل تلك الحادثة من ظلم بين ، وعنت شديد ، ومـا تعرضو الــه مــن قهـر

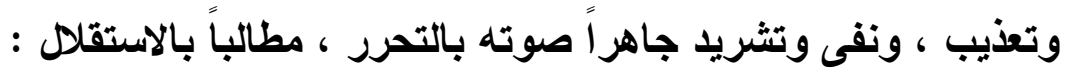
تقلم يحمى "دنشواى"وقد جسرى بها الظلم و العدوان و الثر منذر كما نصــبت فيها المشانق جهـرة لكل فتى حر من العـار ينفــر

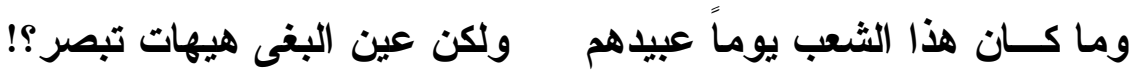
أمسن أجل أفاق يصيد حمامــــة تساق الضحايا كالذبائح تنحر؟! وتثنــق بالحبل المهين رجولة تثــور لعرض يستبـاح ويهــدر ويــؤخذ للسجـن البرئ تعسفاً: ويجلد بالســــوط الأبي الغضنفر ألا إنــــا هو الظــلم صـــــارخاً: وهذا هو الكفر الذى ليس يخفر!! متى كان فى شرع الحضارة عندهم إهانة شــب للكرامــــة يثأر ؟! منى كان فى القانون تثريد آمن إتخريب أحياء إلى الله تجأر ؟! لذلك نادى بالتحرر ( مصطفى ) فقيم يضير الغاصبين التحرر ؟!(')

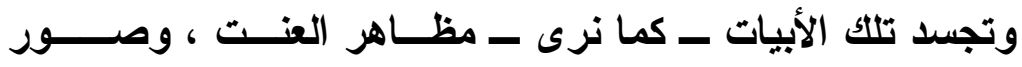
العذاب ، و ألوان الاضطهاد التى مارسها هذا العدو الوحشـي وأتباعـهـ

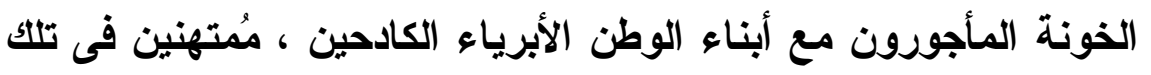

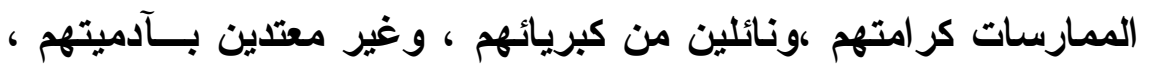


مشيعين فى الأرجاء التخريب و الفساد ، ضاربين فى ذلك بما تتثندق بــهـ

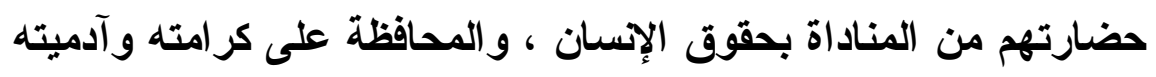

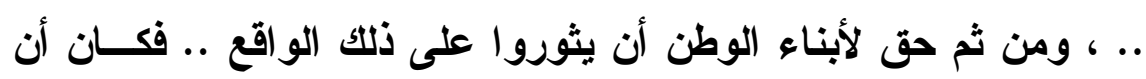

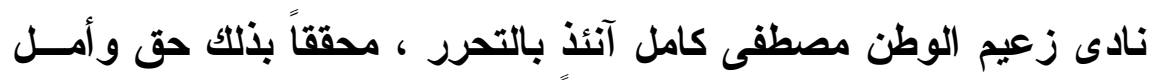

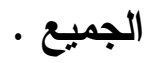

وتثيع فى هذه الأبيات - كما نرى - الألفاظ الرائقة ، والكلمات

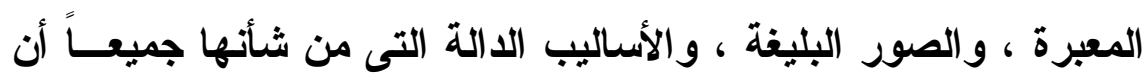

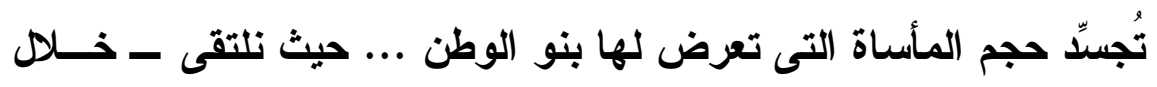

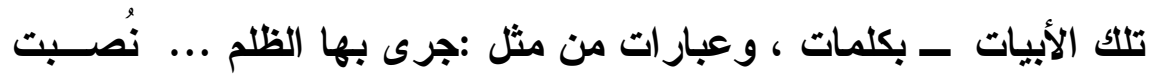
فيها المشانق ... تساق الضحايا كالذبائح تنحر ، ، وتثــنق بالدبـل المهين رجولة . .

كما نلتقى بتلك التساؤلات المتتابعة الدالة المعبرة الناطقة بحجم وطبيعة تلكم المأساة ، و المجسدة لطبيعة وحقيقة مرتكبها: متى كان فى شرع الحضارة عندهم إهانة شعب للكر امة يثأر ؟! متى كان فى القــــانون تثريد آمن وتخريب أحياء إلى الله تجأر

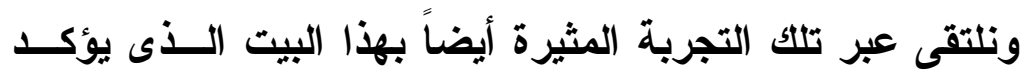
الثاعر من خلال أسلوب القصر الكائن فيه حقيقة هذا التصرف المقيت ،

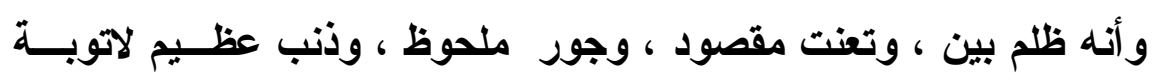
منه ....

ألا إنــــا هو الظلم صارخاً: وهذا هو الكفر الذى ليس يغفر!! 
ولنا أن ننظر بعين التأمل إلى تلثك الصورة التثــبيهية الرائقــة

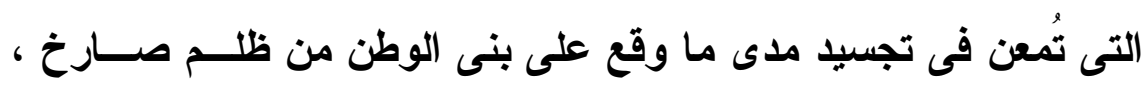

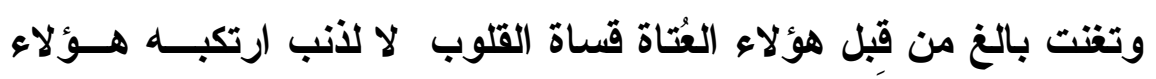

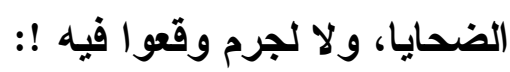

أمن أجل أفاق يصيد حمامة تسماق الضحايا كالذبائح تتحر !!

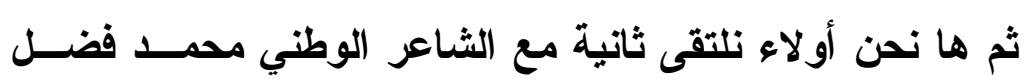

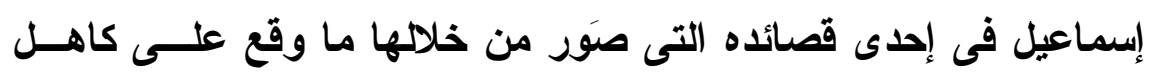

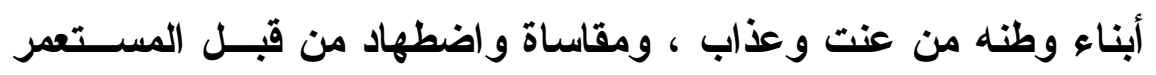

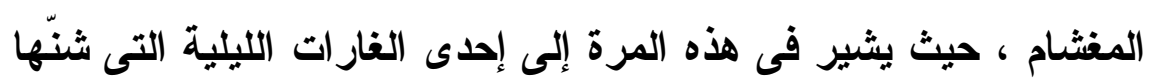

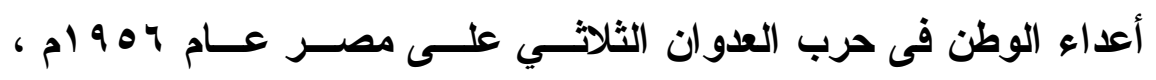

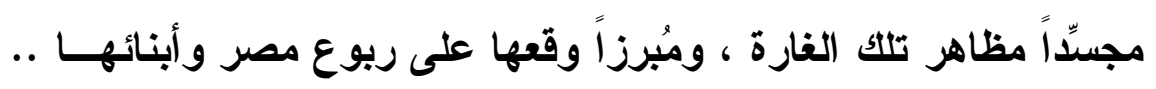

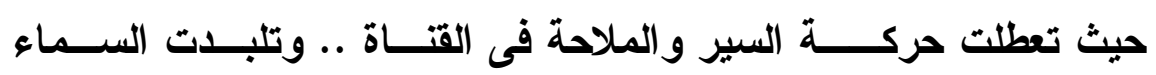

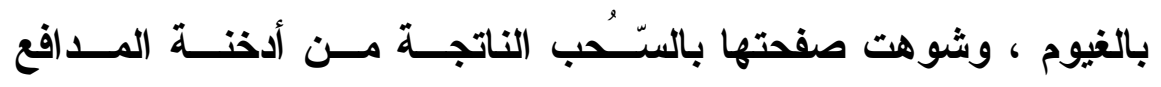

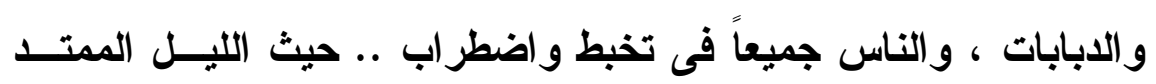

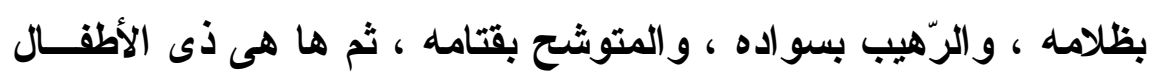

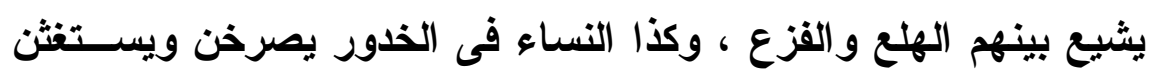

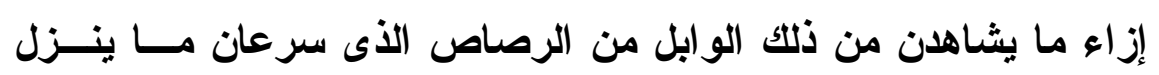

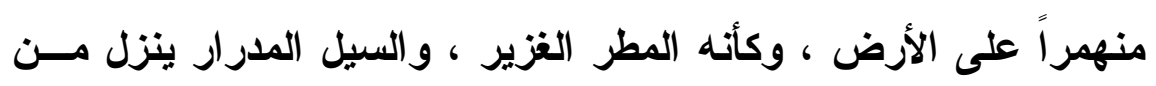
السماء فيهطل على الأرض فيفجرُ فيها العيون.

والثاعر يُصور تعجبه ودهثته إزاء ذلك الخطر المُحدق وكأته

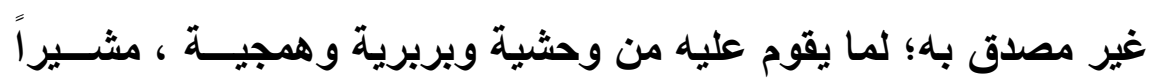

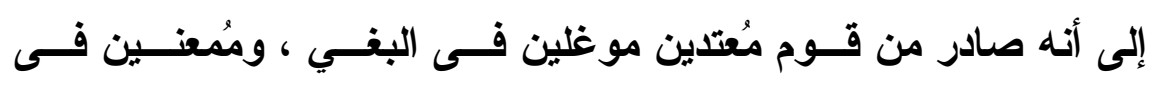


الاعتداء ، ليس بينهم وبين أبناء مصر المجنى عليهم صلة ولا قربِى .. لنستمع إلى الثـاعر وهو يُجسد لنـا تلكك المأسـاة فى لوحة فنيــة رائقــة تفيض بالألفاظ والتر اكيب والصور البليغة المعبرة .. حيث يقول :

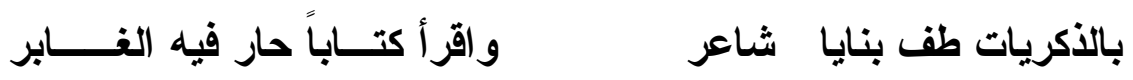
فى كل سطر منه غدر سافر

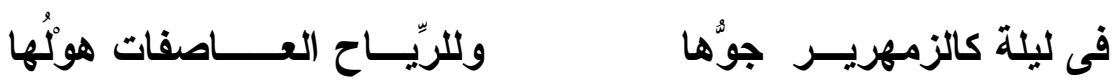
دَهَى السيَّقين فى القناة ما دهى وشوهت وجه السماوات السحب!!

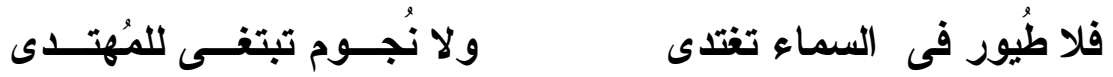

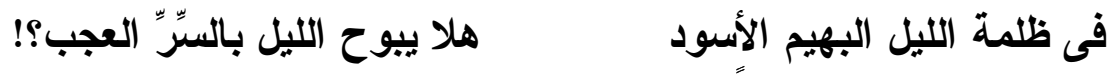
على الضفاف رُوعت أطفالنا افى الخدور استنجدت نساؤنا

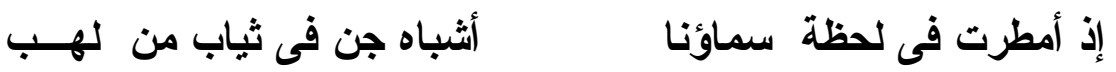
يا رب ما هذى السماء الماطره يهـا أبابيل العـــاب الطــائره؟! بل كيف دارت يا إلهى الدَّائره وما لأهل الفعل فينا من نسب؟!(1) والبيتان الأولان ينبئ الثاعر -من خلالهما -عن كثرة ما مـرّ بمصر وأبنائها من محن ، وما وقع على كاهلها من مآس ، وما تتــابع عليهما من نوازل تثقد منها الحنايا ، وتلتهب الضلوع ، وتذوب النفوس

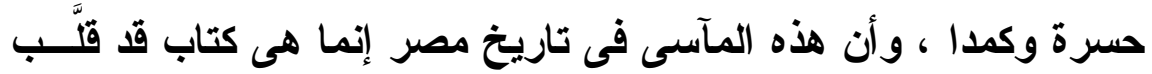


الثُاعر هنا إحدى صفحاته ، وبعضاً من سطوره !! دفعته لأن يتســاءل

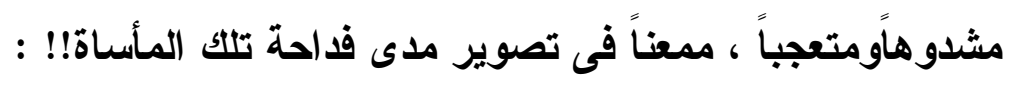
يا رب ما هذه السماء الماطره فيها أبابيل العــــاب الطائره!!

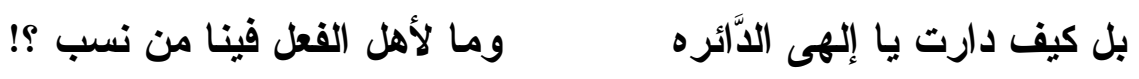

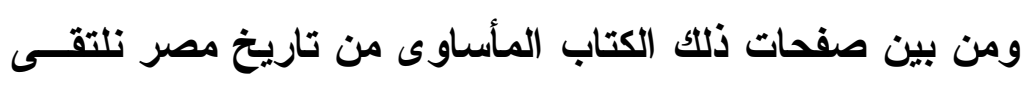

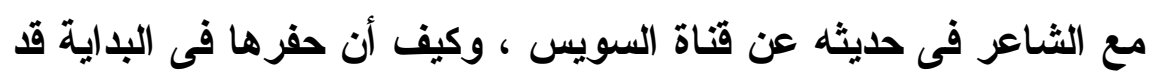

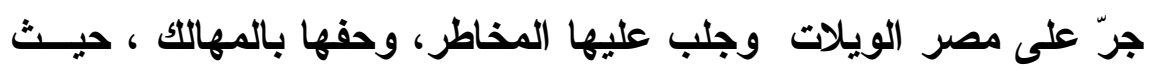

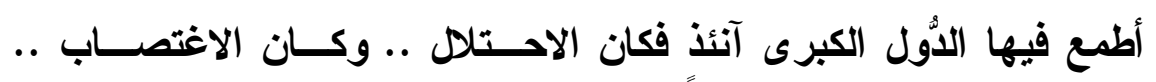

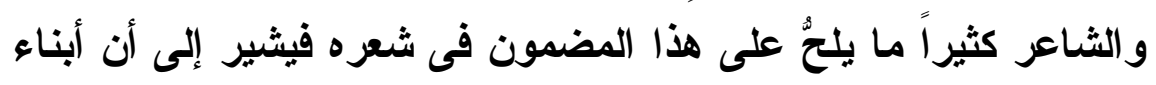

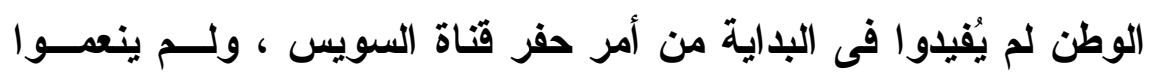

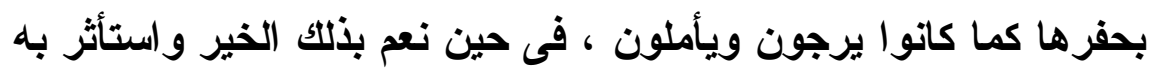

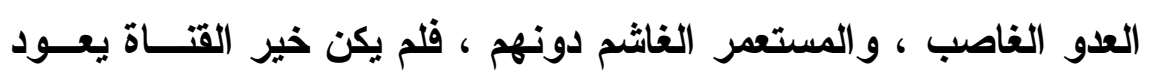

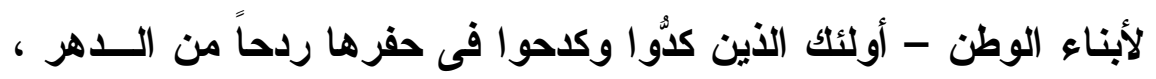

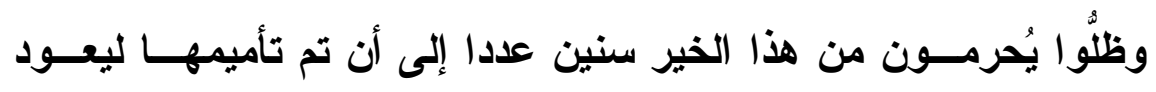

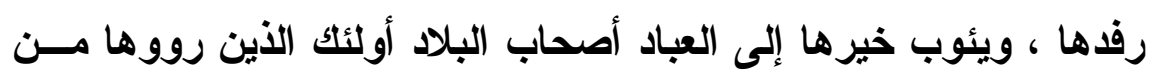

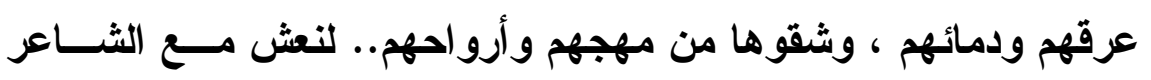

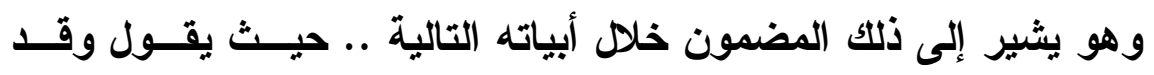
زاوج فى حديثه عن قتاة السويس بين نفعها وضرها :

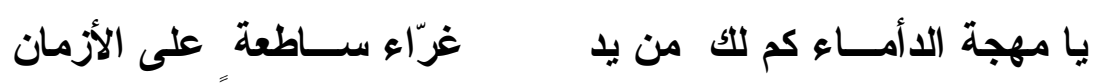

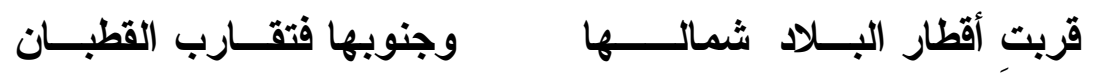
ووصلت أثثطان التجارة بعضها بعضا فكاتت أمتن الأثثطـــان 


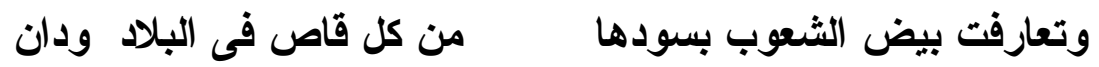

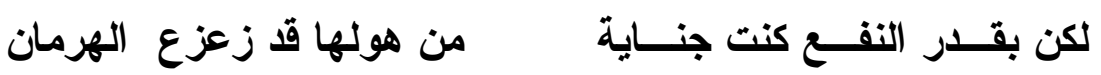
ومصيبة نزلت بمصر فأصبحت تبكى لــها جزعاً بامــع قانى ماذا جنى أبناءع مصـــر وإنهم بين الورى لأئمة الإحسان ؟!

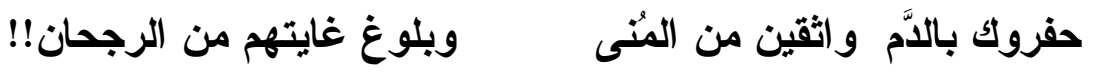

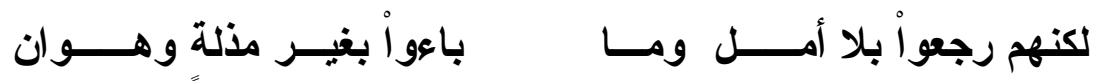

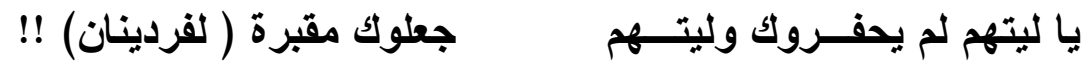

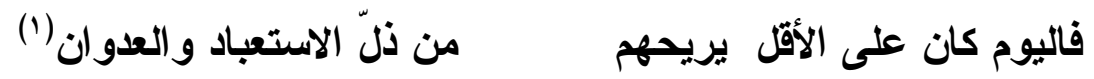
ونرى الثاعر يلح على تجسيا مظاهر العنت والعذاب ، والمشقة والحرمان الواقعه على كاهل أبناء مصر الكادحين - وهم بصــدـ حفــر

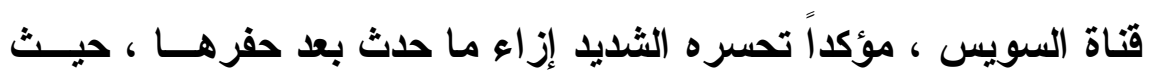

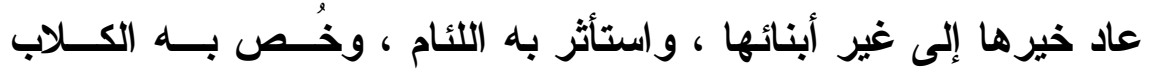

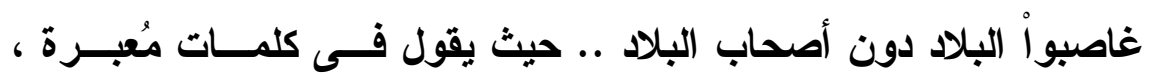
وعبار ات دالة ، وتر اكيب موحية :

وكنا ضحاياك بين الأسـام حفرناك بالام فيما مضى فلم نلق غير حياة اصطدام وصلنا الحياة بأسبابها ومأدبة دُس فيها اللأـــــام ولم نلق غير اعتداء وبغى

(' ) الديوان صـ . 1 ، وفردينان ديليسبس - القائم على مشروع حفر قناة السويس آنئذ . 
وما ساد فى جوفها من ظلام

ولانجلتر ا طال ليل المقــام

كئوس المذلّة فى كل عام!!

جــزاء سنمار فيما أقام!!

ألا إن هذى الأمور حرام؟!

لمقصلة الأبح سوق السهُوام؟!

ونظمأ حين يجود الغمام؟!

فقد كنت داء البلاد العقام!!

وردت الكروب وعز المنام

صبيناه صبابتلك الرجـام

كما حط فيه أخس الهوام

وطاف الشقاق به و الوئام

سنبلى بما لا يحب الكر ام

فعم .. ويتنا بغير الطعام

ولم ندر أنا بهذا نضام !!

وقيداً مُهيناً بغير احترام(1)
ولم نلق غير عناد الليــالى

فأغــرت فرنــسـا بأوطانتـــا

ثماتيــن عامـــا شربنــــا بها

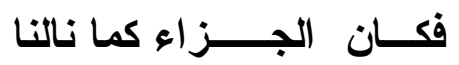

أنغرس ورداً ونجنيه شوكاً

بأي كتاب تساق الثــوب

وفى أيّ شرع تداس الحقوق

عفا الله عنك قناة السويس

جرحت القلوب وسقت الخطوب

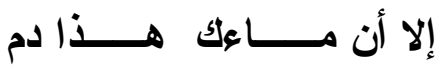

وقد ولغت فيه شر الأيـــاب

ومرّ" بـــهـ كلّ قة قــــاص ودان

ولم ندر يوم حفرنـــــــاك أنـا

فتحــنـا بك الرزق للعالميـن

أردنـا لمصر مكــــاناً علـيا

ولم ندر أنـا ســنلقى احتــلالا

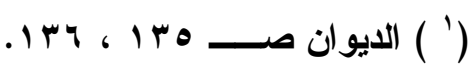


ويبدو لنا جلياً خلال تلك الأبيات كيف أن الثناعر يلح على إبراز

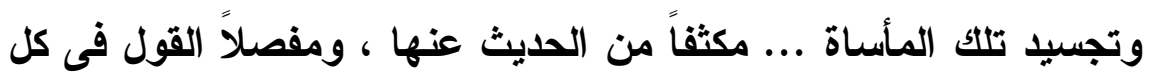

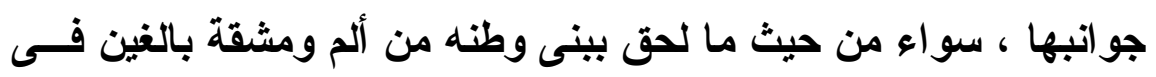

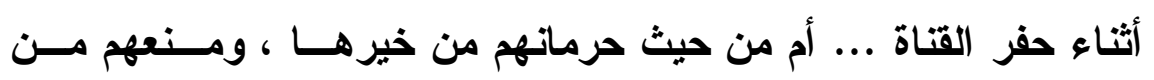

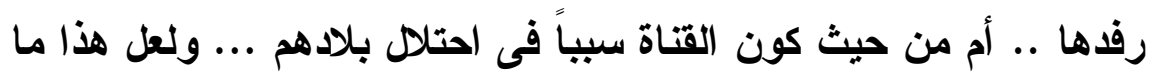

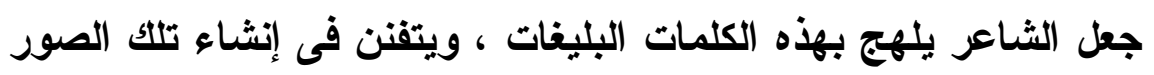
الر ائقات ، حيث يقول :

صيناه صبابتلك الرجسام

كما حط فيه أخس الهوام

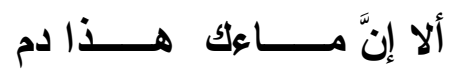

وقد ولغت فيه شر الأنــاب

فما أبلغ ، وأدل فى التعبير عن تلك المأساة من هـــا التثــبيه

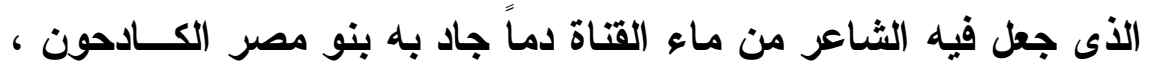

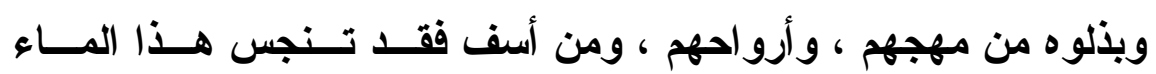

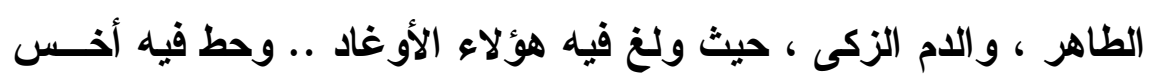

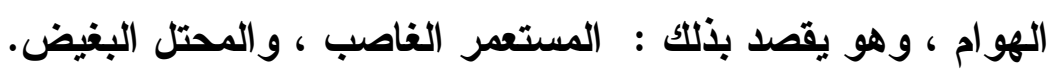
ثم ما أبلغ تلك التساؤلات الإنكارية المتتابعة ، وما أثثدها دلاعــة

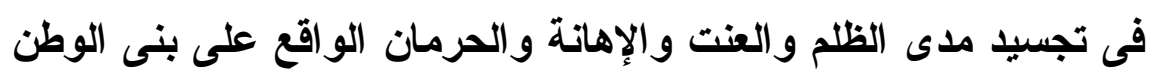

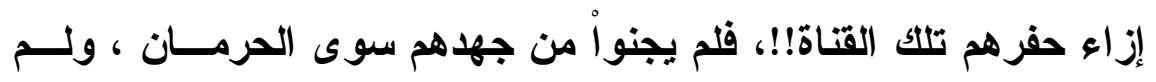

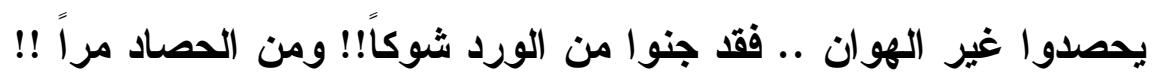

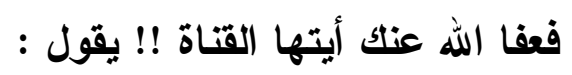
ألا إن هذى الأمور حرام؟! أنغرس ورداً ونجنيه شوكاً
لمقصلة الأبح سوق السوُو ام؟! بأى كتاب تساق الثــوب 


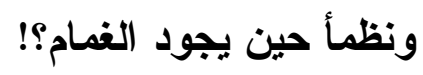

وفى أيّ شرع تداس الحقوق

فقد كنت داء البلاد العقام!!

عفا الله عنك قناة السويس

و إمعانـاً من الشاعر فى تجسيد حجم المأسـاة ، وتصوير طبيعتهــا

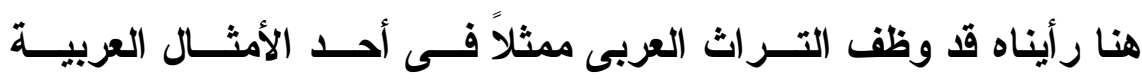

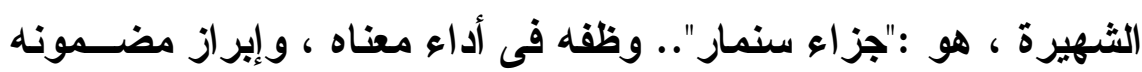

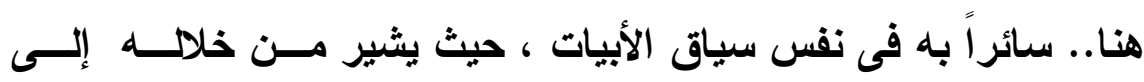

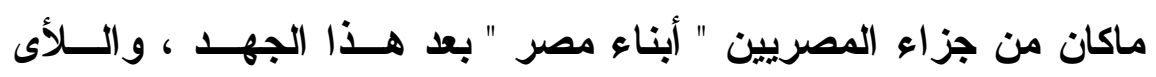

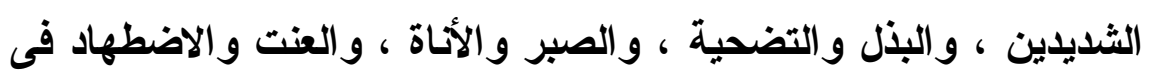
حفر القتاة من الحرمان من خيرها ، والحصاد المر من جنيها ... حيــ ولث

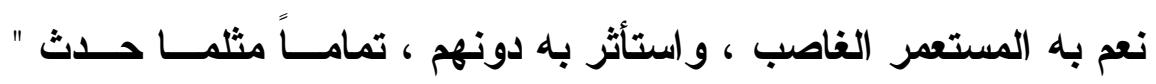
لسنمار" ــ ذلك المهندس البارع فى التشييد و البناء ـ ـ الأى شيد لأحــــ الأمر اء قصراً تفنن فى إتقانه و إتمامه ، وبالغ فى تزيينه وتنميقه حتـى بدا فى صورة جميلة ، وهيئة بليعة نادرة المثال ، وحتى يضمن الأميـر

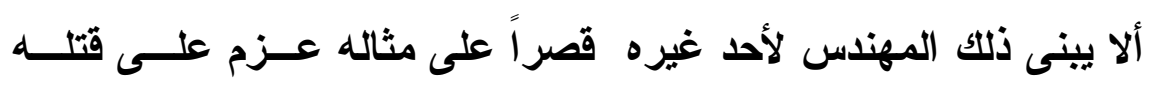
مقابلاً بذلك الإحسان بالإساءة ، والعرفان بالجحود ، والنعمة بالنكران! فقيل :" جزاء سنمار" . .وهكذا كان حال بنى الوطن إزاء قناة الســويس

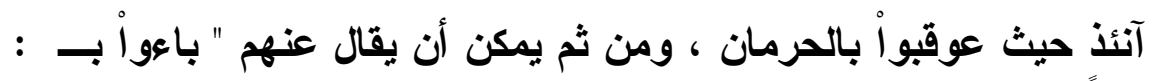

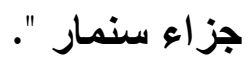

ثالثاً : حث بنى الوطن على العمل على ما فيه نهضــة ورقـى وطنهم ، ودعوته -أى الثاعر - إلى (فتدائه بالنفس والنفيس ، و إلحاحه فى دعوته بنى وطنه إلى أن يتسلحوا فى جهادهم المستعمر ، والوقوف ولى 
فى وجهه بسلاح العلم والأخلاق ، مؤكداً أن ذلك هو الطريق إلى التحرر و السيادة ، و السبيل إلى التقدم والريادة .

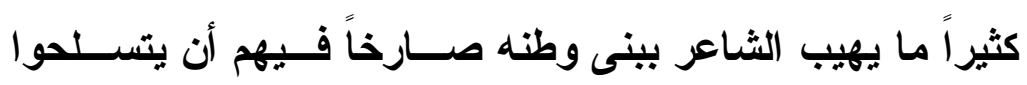
بالعمل على ما فيه رقي ونهضة وطنهم ، وذلك من خلا أخذهم بأسباب

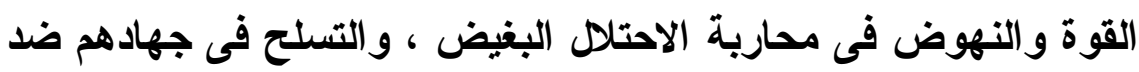
المستعمر الغصوب ، و الوقوف فى وجهه بسلاح العلم ،والأخلاق..مؤكداً

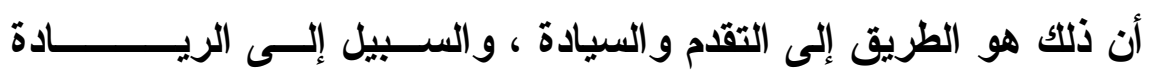
و التمكين .

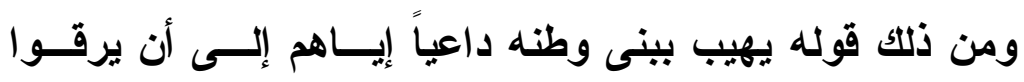

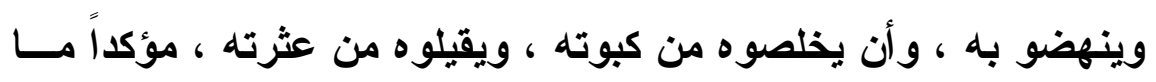

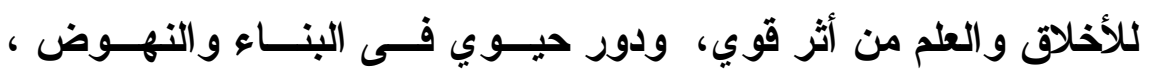
و أنهما سلاح الأقوياء ، و السبيل إلى النصر ولئ ودور والتمكين : صوتها الإيمان من لدن الوفاء فاجعلوا أيامكم أنثــــــــودة

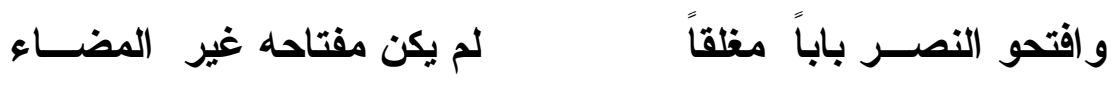

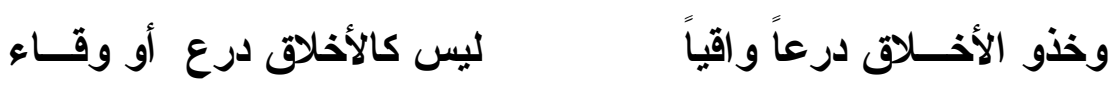
و انهضوا بالعلم عن أجدادكم فهو فى الانيا سلاح الأقوياء(1) و الثاعر فى البيت الثانى ـ ذنلك الأى يؤكد فيه ما للأخلاق مسن

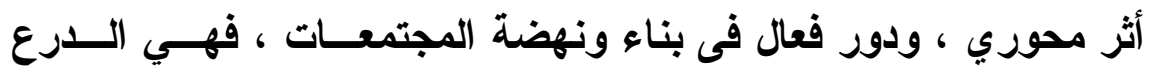

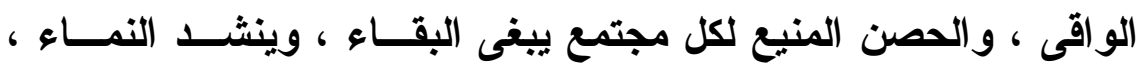


ويأمل فى الإصلاح و البناء ، وبدونها ــ أى الأخلاق ــ ت أتهاوى أركسـان

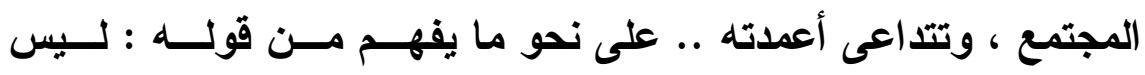

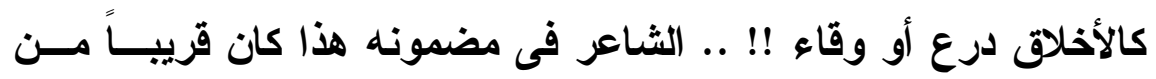

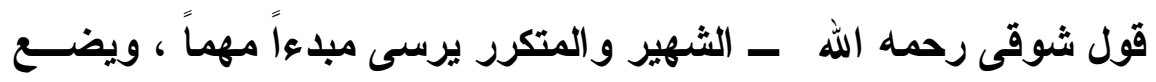
قاعدة راسخة ، ويقرر حقيقة ثابتة لا تتخلف قط ، ولة ولا تغيب أبداً :

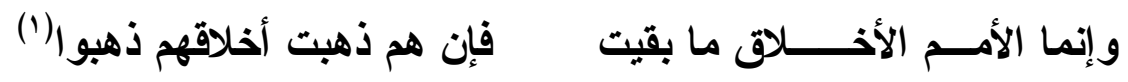
كذا الناس بالأخلاق يبقى صلاحهم ويذهب عنهم أمرهم حين تذهب(ץ) ولا المصائب إذ يرمى الرجال بها بقاتلات إذا الأخــلاق لم تصب(م)

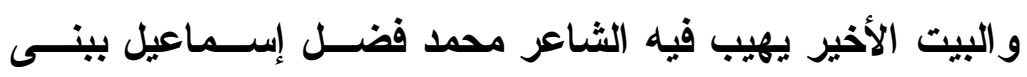

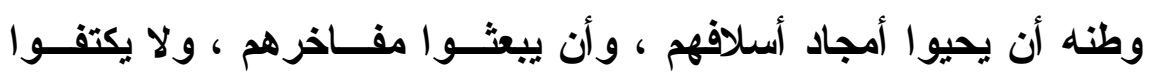

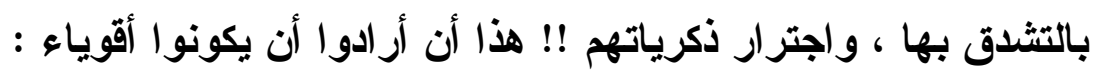
و انهضوا بالعلم عن أجدادكم فهو فى الدنيا سلاح الأقوياء

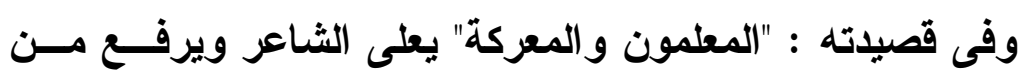

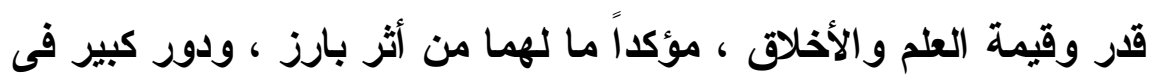

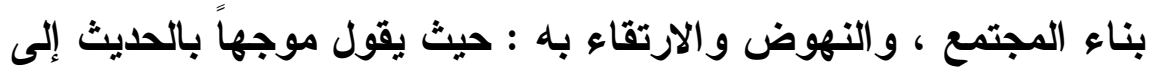

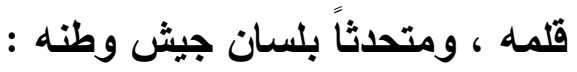
حدّث ير اعى عن الأخلاق و الأدب و ادع الثهامة وارفع رايـة العُرب

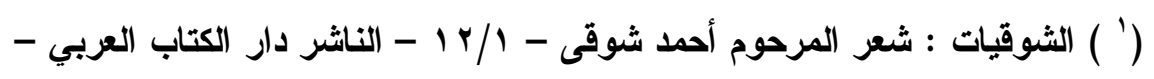
بيروت - لبنان . البدي

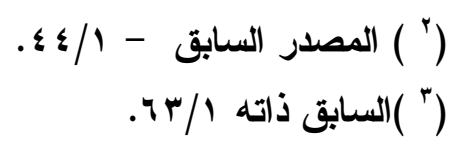


و اقر أ على هذه الدنيا رسالتنا اضرب على الجهل بالأسداد والحُجب

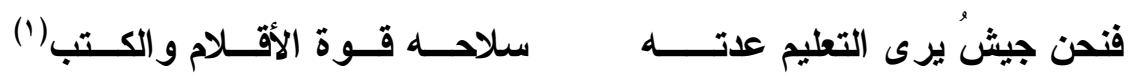

وهو يتحدث خلال تلك الأبيات ــ بلسان المقاتلين الـــين نـــروا

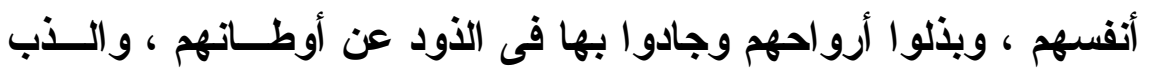

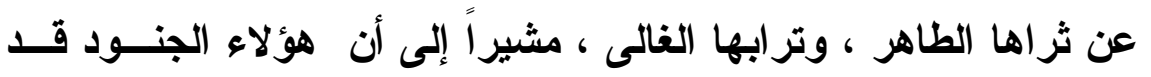

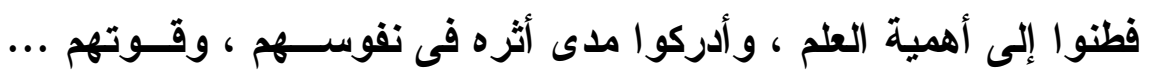

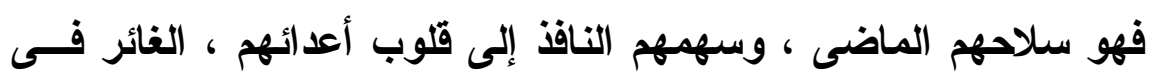

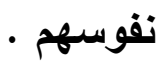

ويلح شاعرنـا على تلك الفكرة ذاتها ، ويؤكدها فى موضع أخــر

من شعره الوطني ، حيث يقرر ما للعلم من أثر كبير فى النفوس ، وأنه السبيل إلى رفعتها ، وتسنمها ذرا المجد والسيادة ، وهو أيضاً الســبيل إلى البناء والتشييد ، وفى المقابل يصور الجهل ، وكيف أنه السبيل إلى ولى وهلي ضياع الكرامة ، وحلول الألة والتبعية : حيث يقول : هو العلم كم أحيا مواتاً وكم بــــهـ تسلَّق أدراج السموات فرق وكم فى ظلام الجهل ضاعت كرامة وذل عزيز فى الحياة وسيد

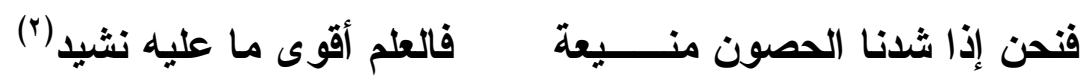
ولايخفى تعبير الشاعر بالضمير: " هو " ـ بجاتب العلم ، ومــــ

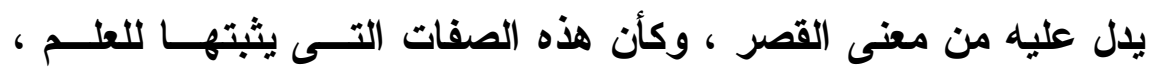


والآثار المترتبة عليه بعد ذلك إنما يختص به ، ولاتتعداه إلى سواه : هو

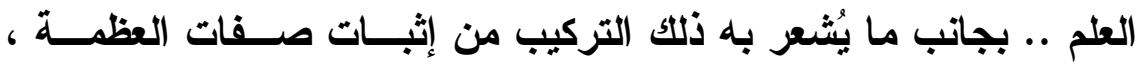

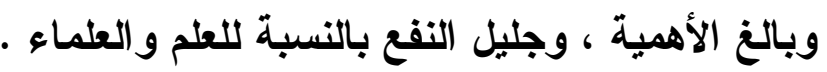

كما لايخفى تعبير الثناعر بجاتب العلم والجهل بكلمـة : " كـــم " وما تدل عليه هنا من التكثير الأى يؤكد المعنى ، ويقويه فى كل : لئل

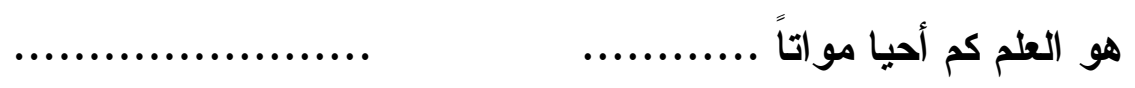
وكم فى ظلام الجهل ضاعت كرامة وذل عزيز فى الحياة وسيد

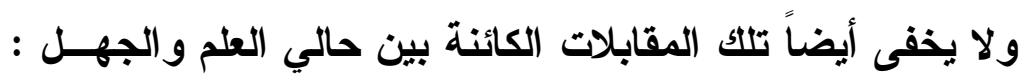

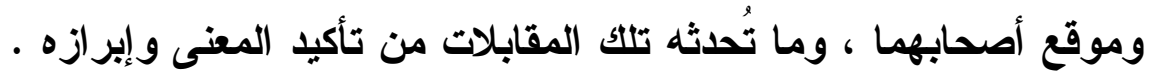

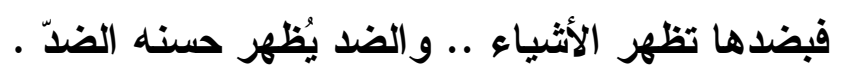

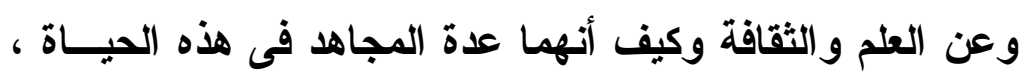

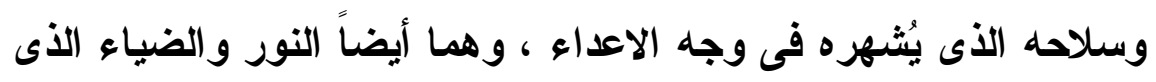

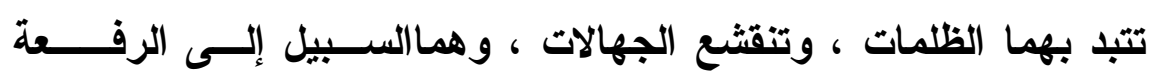

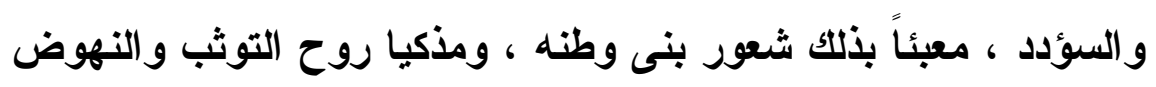

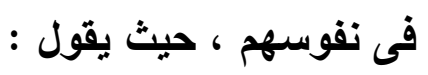

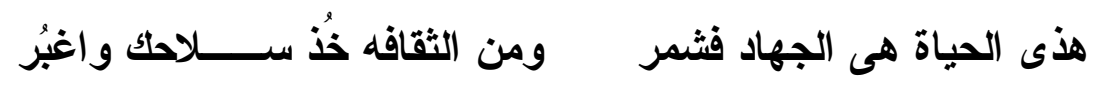
كن كوكباً ما بين قومك هادياً: وابعث شعاعك بالضيـــــاء ونور هيهات يوماً ان يقال له امرؤ من عاش أعمى القلب لـــ يتبصــ!!!(')

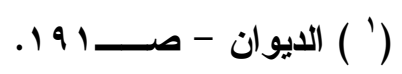


ومن النماذج الجيدة ، و المثيره فى شعر محمـــ فضــل إبــماعيل

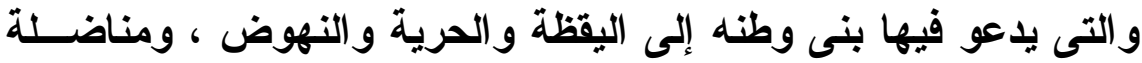

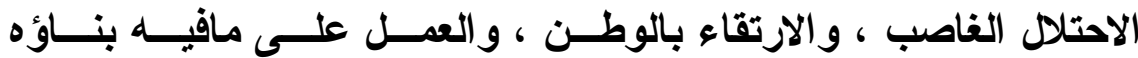

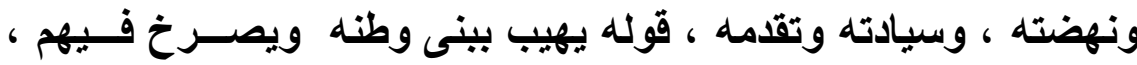

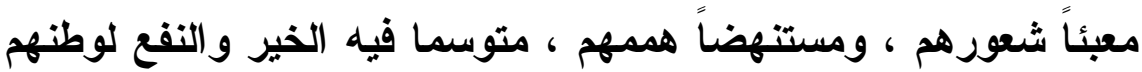

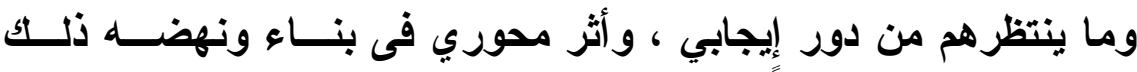

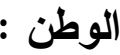

و الاتجاه لجني الخـير و الثـــر فواجب الشعب إيمان بثــورته على العزيمة فى الأعمال و الفكر و الاعتصام بحبل الله معتــــــاً لا تسـتريح إلى شر ولا ضرر يدعو الى الخير مدفوعاً بعاطفة بالمستخف ولا بالمارق الأثــر توروا على كل معوج ولا تثقوا نحو الرقي فأنتم خبــر مدخر(') - ن فمصر ثائرة فامضـو بها قدماً .وهكا يبدو شاعرنا -خلا تلك التجارب - فى صورة المحسب

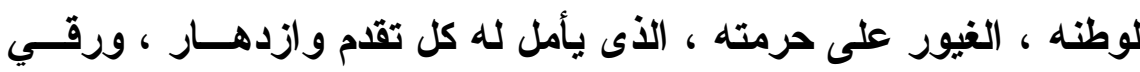

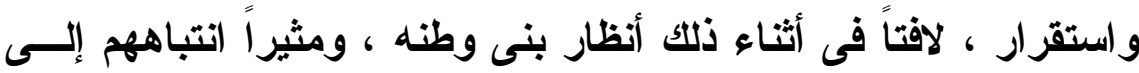

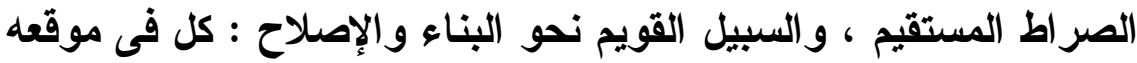
يؤدى ما عليه من دور يُرجى ، وواجب يُنتظر منه ، وأمل يُطلق عليه . 
رابعاً : الإثـادة بزعماء الوطنية ، وباعثى نهضتها ، وقادة الأمة

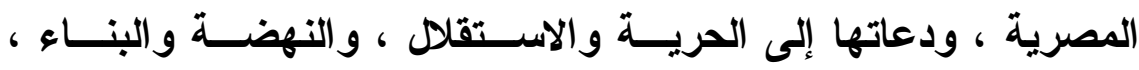

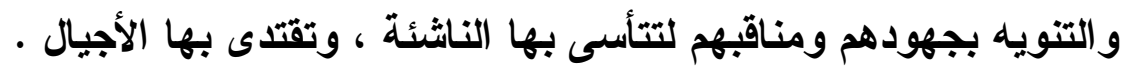
لقد جادت مصر بالعديد من أبنائها البررة ، ورجالها المخلصـين

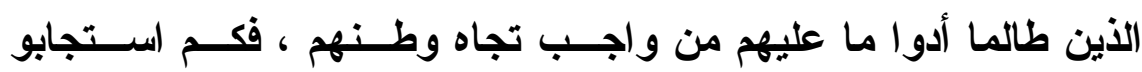

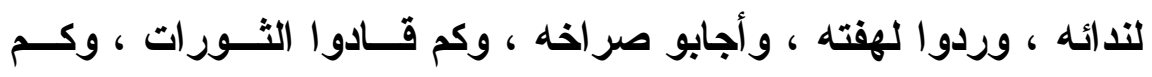

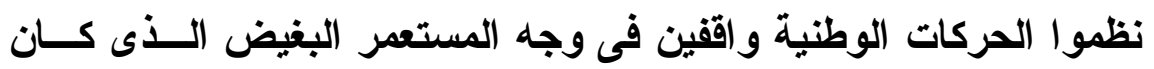

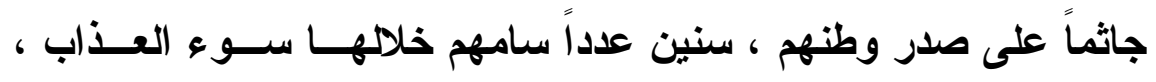

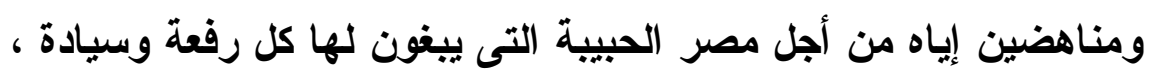

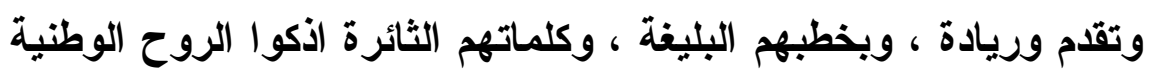

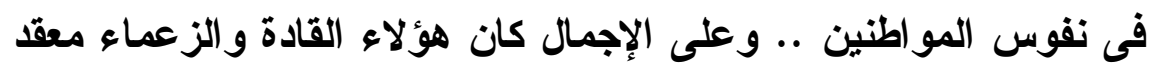

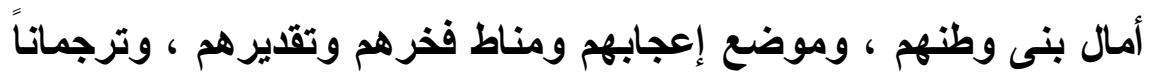

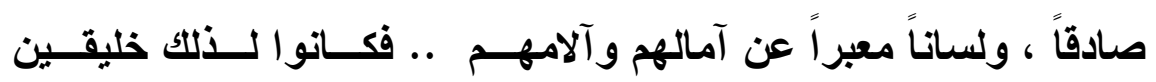
بالتقدير ، جديرين بالثناء على مر الدهور وتعاقب العصور و...

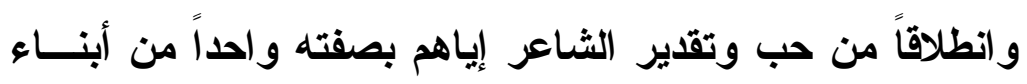

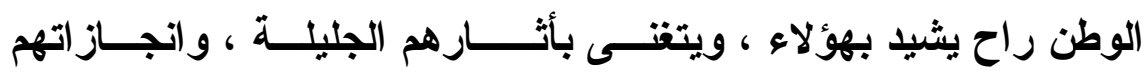

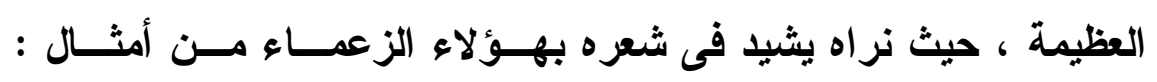

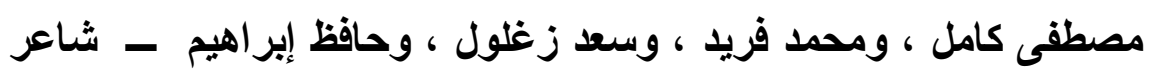

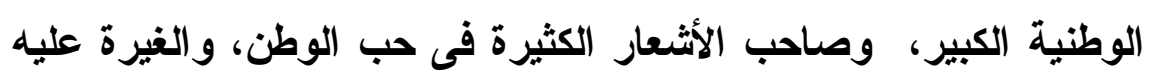

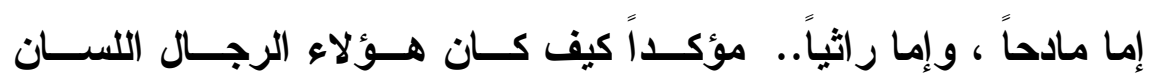

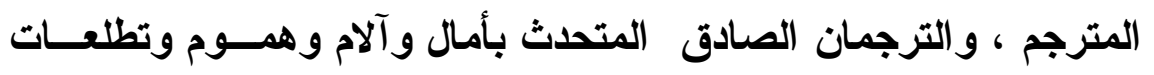
وطموحات بنى وطنهم ... 


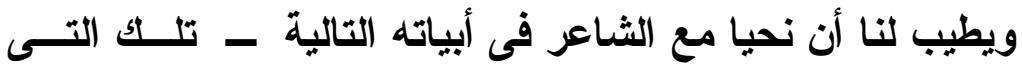

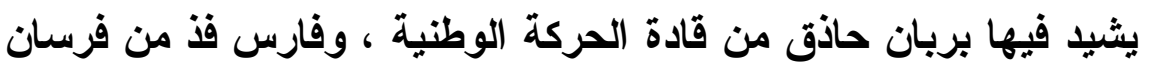

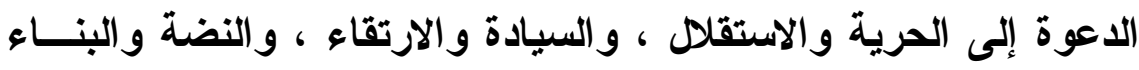

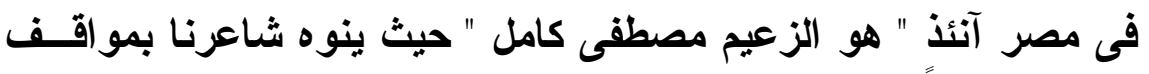

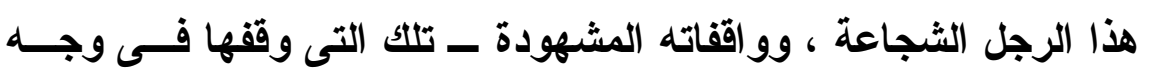

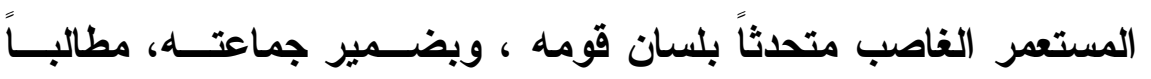

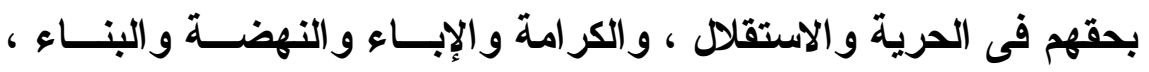

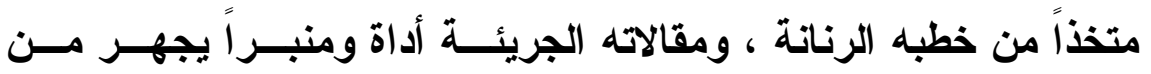
خلالهما فى التحدث بآلام و آمال وطموحات بنى وطنهاته، حيث يقول : فهل يعرف المصرى ما قبر مصطقى ومن (كامل )هذا إذا اهتز منبر؟! ومن صاحب الصوت الددوى الذىعلا ينادى بتحقيق الجلاء ويجـهـر ومن علــم المحتـــل أن حقــــوقنا حقوق عليها أعين الثعب تسهر

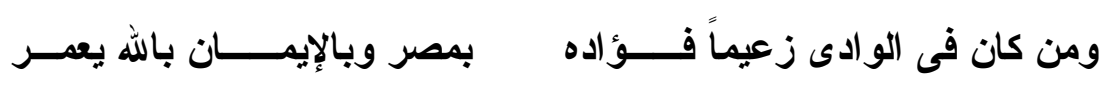

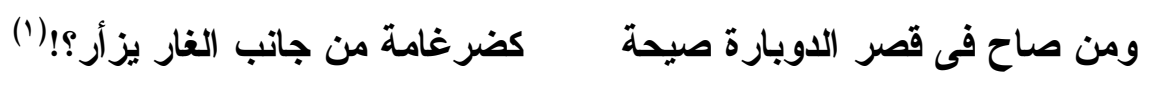

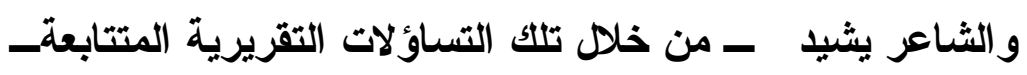

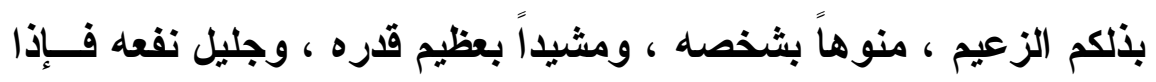

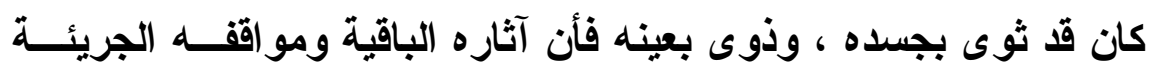

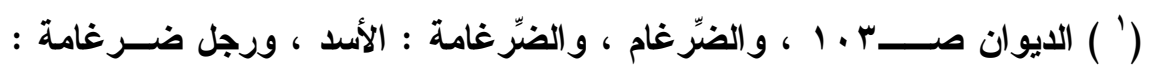

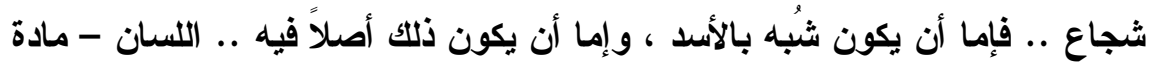

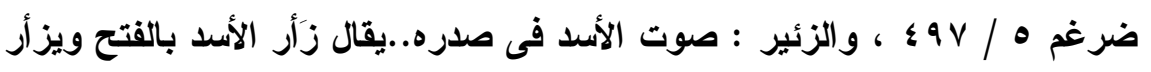

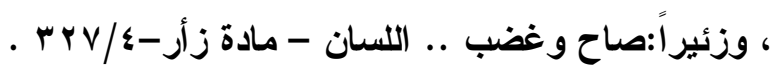


التى تفيض بخطبه الرنانة ، وكلماتــهـ المدويــة ، وصــوته الجهيــر ،

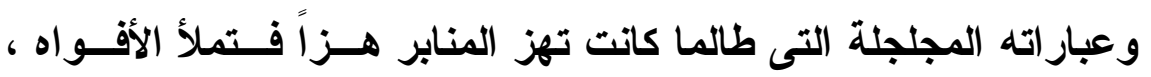
وتقرع الآذان واقعة على المستعمر وقوع الصاعقة ، وماضـية مضـــاء

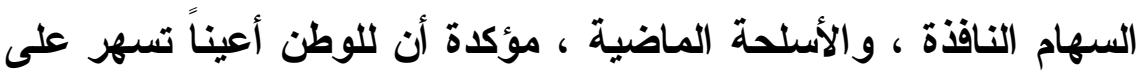
المطالبة بحقه فى الحرية والاستقلا والنهضة والبناء فى ثبات وإصرار وشجاعة واستبسال .. كالليوث فى عرينها ، و الصقور فى أوكارهــا ... يحدوه فى ذلك ويدفعه إيمان صادق ، وعقيدة صــحيحة .. يــأتى حسب ، الوطن وافتداؤه بالغالى و النفيس مظهراً من مظاهرهما ، وجزعاً أكيــــاً من كيانهما :
بمصر وبالإيمان بالله يعمر

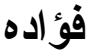

والأبيات المذكورة تقرر كُلها حقائق ، وتؤكد مواقف اضطلع بها

ذلكم الزعيم ، وهى جميعاً تنطلق من خلال مطالبته بالحرية والاستقلال ،

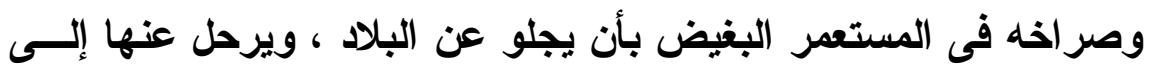
حيث لا رجعة .

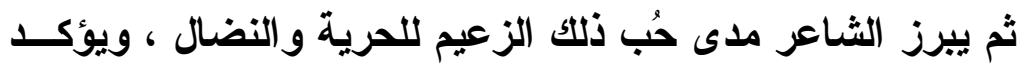
حرصه على تحقيقهما من خلا أبياته التالية - تلك التى يشير فيها إلى دور مصطقى كامل البارز ، وموققه الجــرئ فــى المطالبــة بالحريـــة

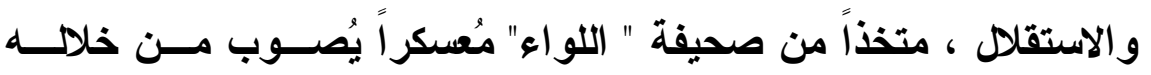

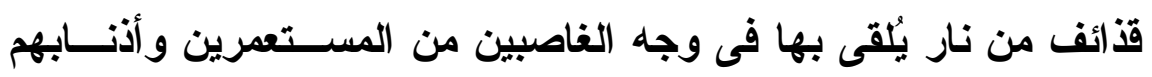

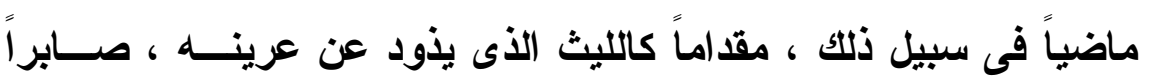

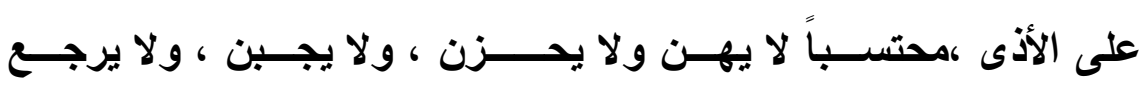

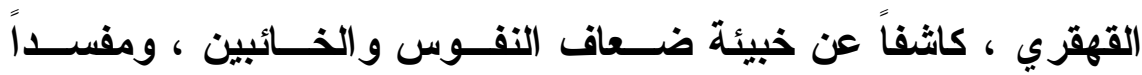




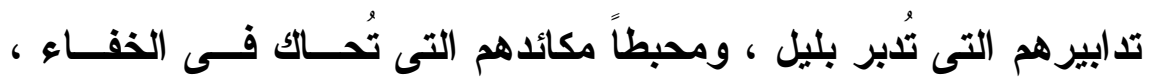

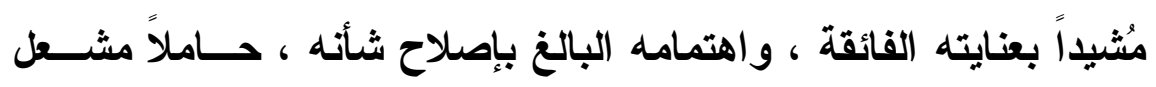

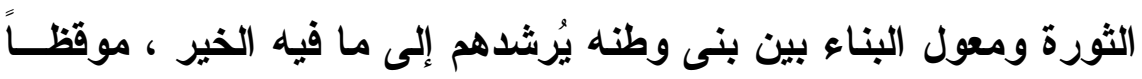

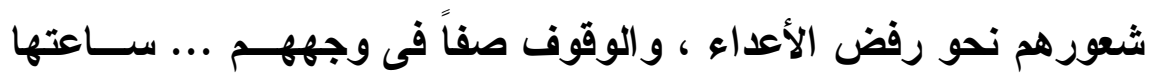
ينعم بنو الوطن بخير اته ، ويحظون بثرو اته - يقول :

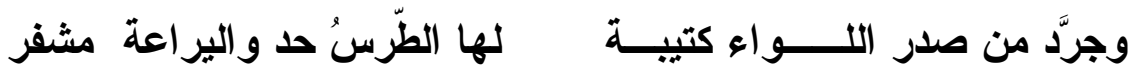
وصوّب نحو الغاصبيـن قذيـفة هى النّار أنى صــوبت تتسعـر وقام كليث الغاب يحمـى عرينــه، صبوراً على الأهوال لا يتقهـقر ودعا لا كتساح المخزيات مُفضحاً: مكائد كانت فى الخفــــاء تدبـرن

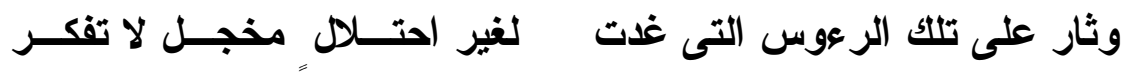
فقام إلى التعليم يُصلــــح شأنــــهـ كما كان معروفاً فى النــاس يأمر ويهدى إلى الحق المبين خصومه وبالظُلق العالى على الخصم يظقر ويُرشد فـــلاح البـــلاد لأرضه و وكيف يُربي الزرع والزرع أخضر؟! وكيف يكون المال فى جيب أهله وكيف عدو الثعب بالثعب يُقهر؟؟ّ(") وهكذا يبدو مصطفى كامل ـ خلا تلك الأبيات ـ فـى صــورة

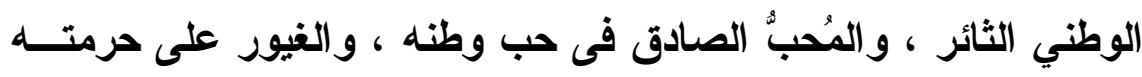

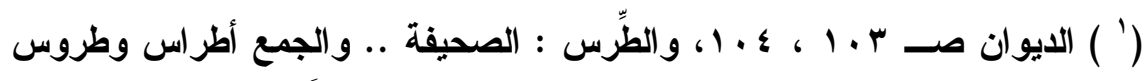

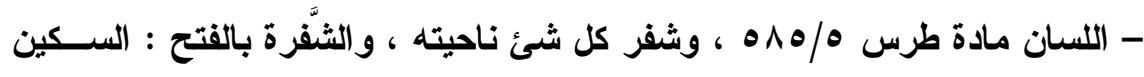

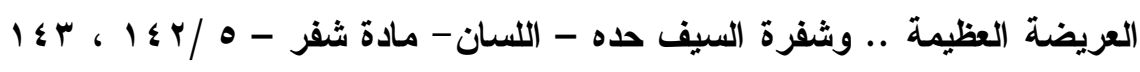




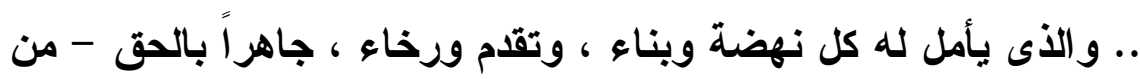

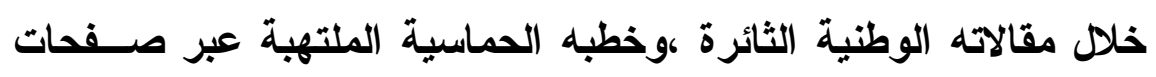

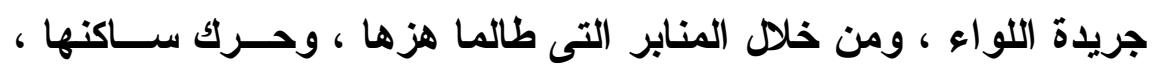

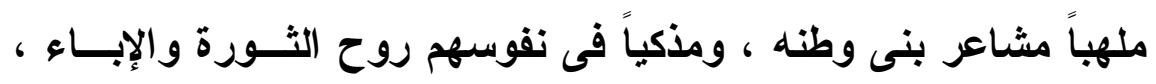

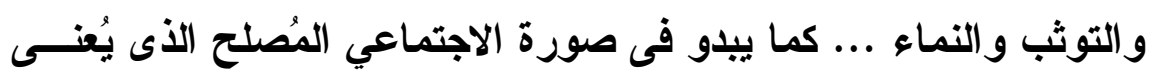

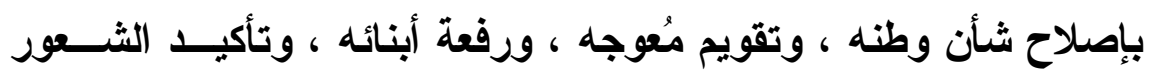

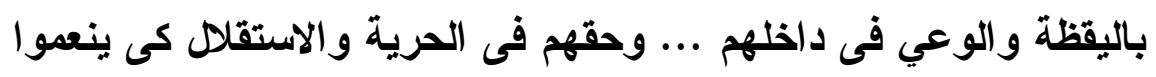

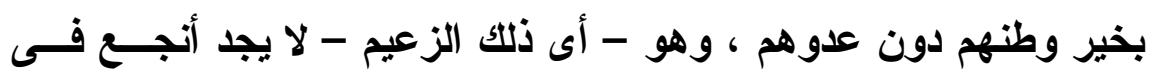

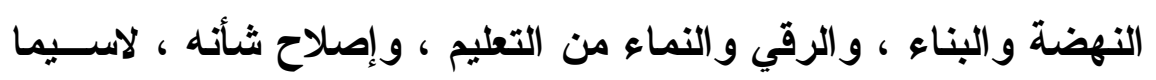

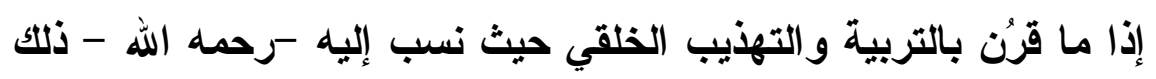

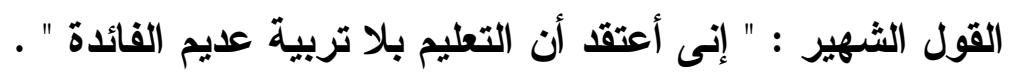

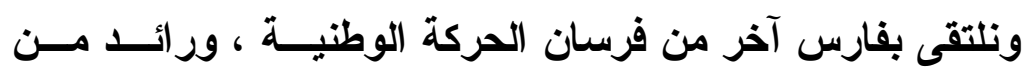

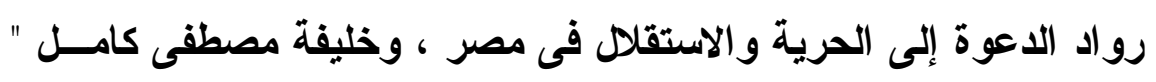

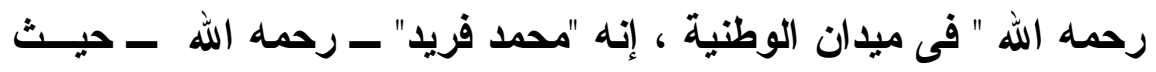

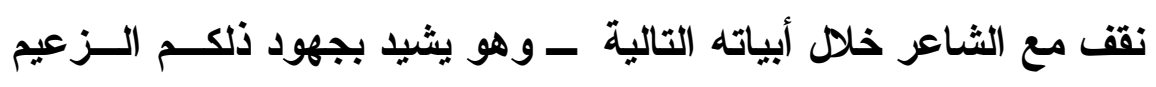

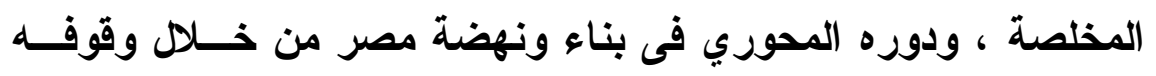

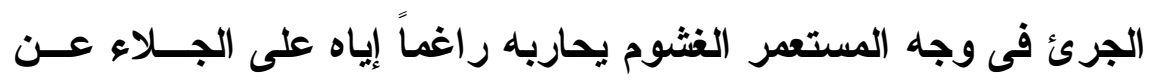

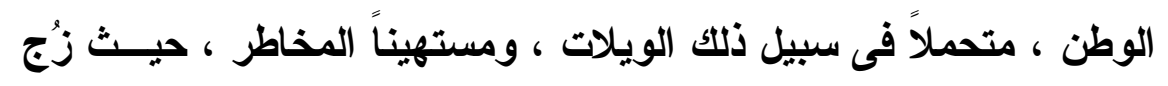

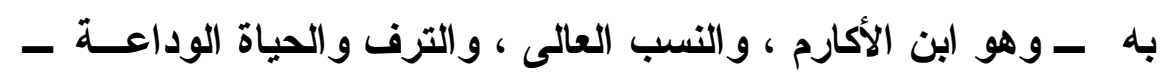

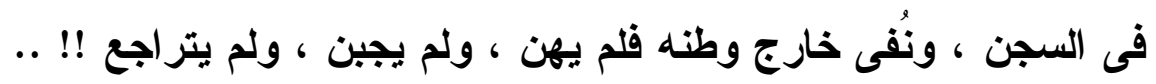

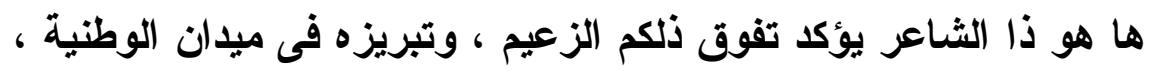


وكونه فى الصدر والطليعة بين فرسان الحركة الوطنية من خلال تساؤله

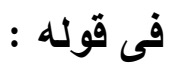

إن أعوز الغاب يوم الهول رئبال!! وهل يُرى كفريد فى طليعتهم

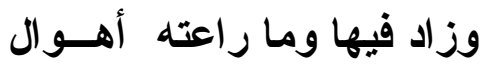
عن مصطفى كامل أدى رسالته ولا شبيه و إن ساعته أحسوال! هذا المجاهد لم يعرف له مثل ماكل رسئ عال تكافأ فيه العـــم والخال!!

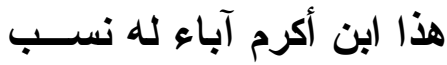
من دون حرية الأوطسان آمال

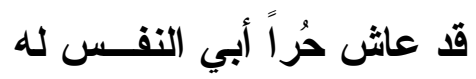
بقوة الله لـــ يمسســــهـ إذلال له ضمير لنور الحق مندفعاً ولا تضارب فيه القـيل و القال

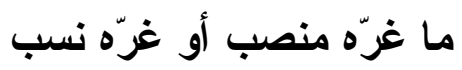
يذهب المنصب المرموق و المال تبقى الكرامة فى الانيا مخلده وكم بها ضربت للناس أمثال!!

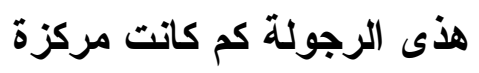
فى كل قلب لها رمز وتمثــال (1) هى الكر امة فى أعلى مر اتبها

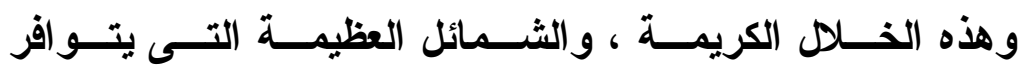
عليهاشخص ذلكم الزعيم لا يشعر بها الثاعر وحده ، و إنما هى محفورة

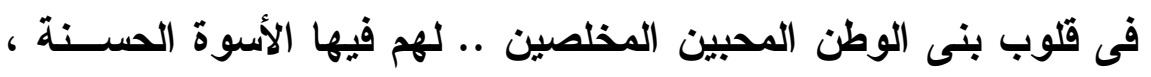
و القدوة الصالحة ، فهى الأنموذج المنشود ، و المثال المُبتغى : " وكم بها ضربت للناس أمثال " ( وهي ) : فى كل قلب لها رمز وتمثثال

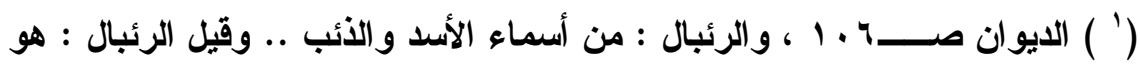

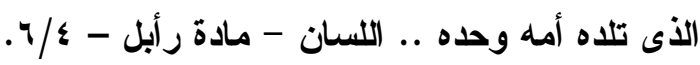


وسيرة ذلكم الزعيم بما تفيض به من مواقف مضيئة ،وما تعمر بــه من جوانب مشرقة تنطق كلها بعظمته و إنســـاتيته وحبــه الشـــيد

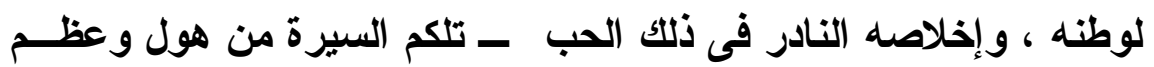
مافيها من مواقف يشيب لها الولدان ...

ومنها ذلك الموقف الذى تعرض فيه للسجن والتعذيب من أجـلـ أن يتحول عن مبادئه ، وينثـى عنها ، ومن ثم يظفر بحريته ، ولكنــهـ ــ وهو الحر الأبى النفس ، الثابث الجأث ، الثجاع القلب ، صاحب الهمة العالية ، والإرادة القوية ، و النفس الكريمة ، والمشاعر الصادقة .. أبى

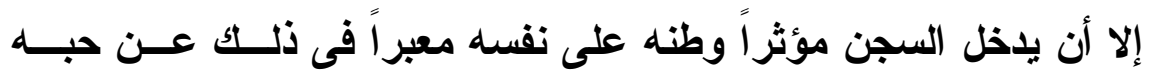

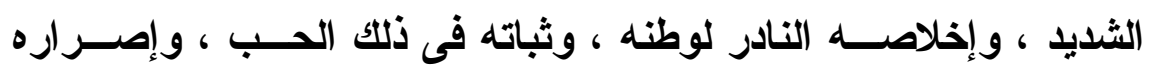

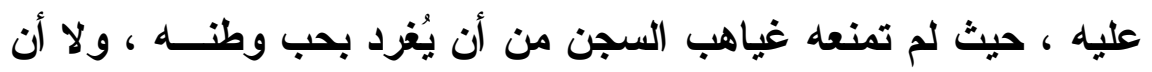

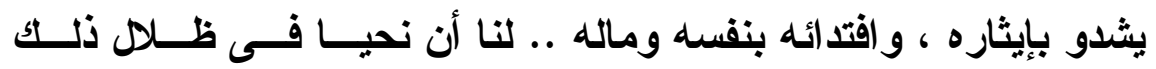
الموقف المُشرق ، والجاتب المُضئ من حياة ذلكم الزعيم - والأى جعل

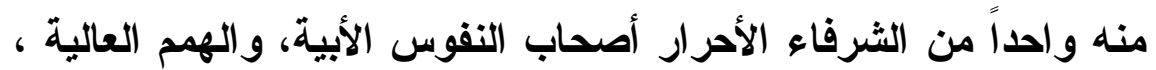
و العزائم القوية ، لنا أن نحيا مع تلك المعانى من خلا قول الثـاعر :

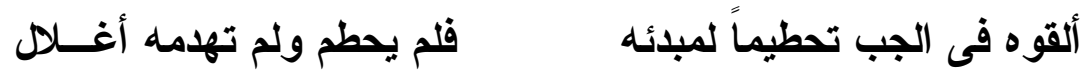

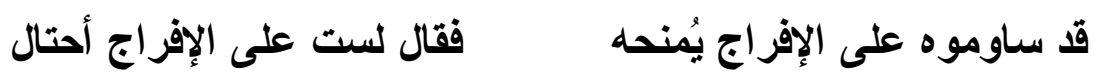

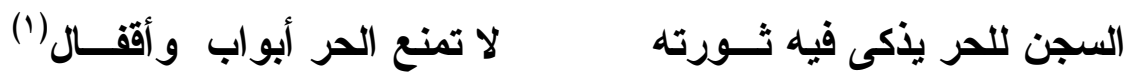
ونمضى مع الشاعر خلا رحلته مع ذلكم الزعيم ، وعبـر أبيات قصيدته تلك .. فنلتقى مع الأيام الأخيرة من حياة " محمد فريد " - 


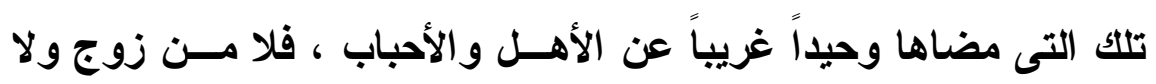

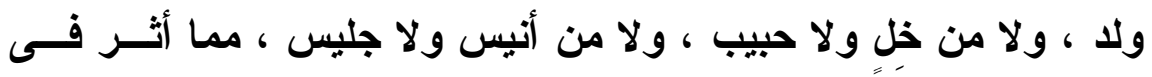

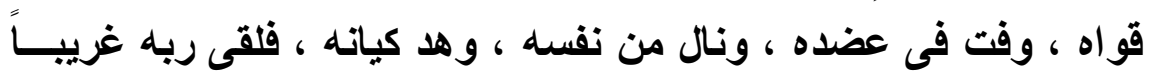

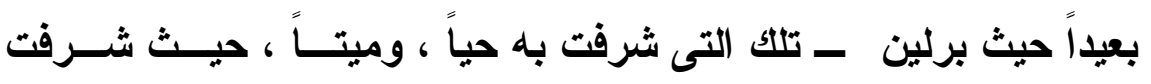

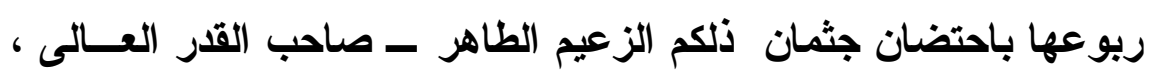

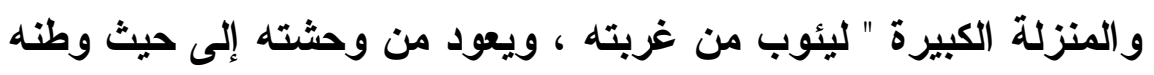

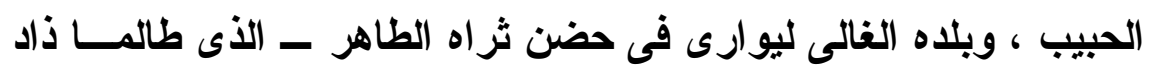

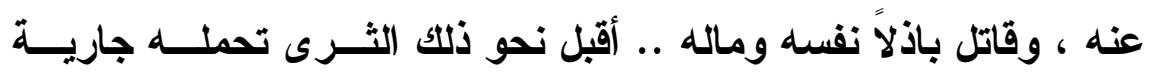

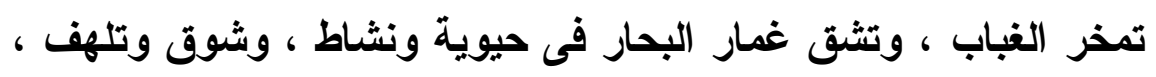

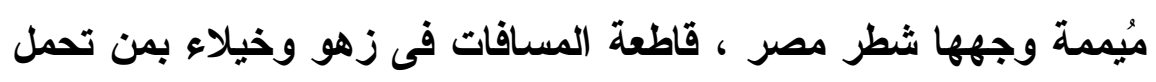

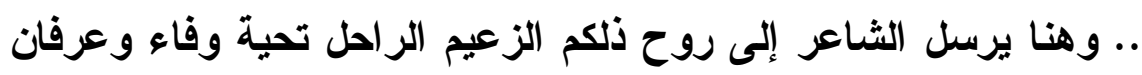
، وتقدير وإجلال تتجدد بطلوع الثمس فى كل نهار ، جاعلاً من حياته " ل

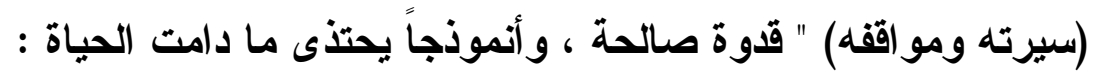
يقول محمد فضل إسماعيل :

وفى الفؤاد لهيب النار فعسال

ولا حبيب له عطف و إقبـــــال

حتى ألم بـه ضيــق و إقــــلال

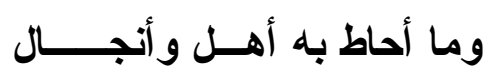

بين المقادر فى الأعلام مفضال

سفينة أقبلت فى اليـم تختــال
فودع الأهل والأوطان مغترباً

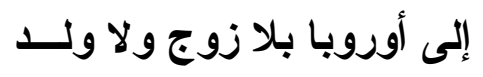
إلى الجهاد عنيفاً وهو مغترب ومات ـ وهو غريب الدار منفرد ضمته برلين جثماناً فثــرفها وعاد لكن على التابوت تحمله 
فيا فريد سلام الله ما طلعــت ش شمس فأنت لنـا نهج ومنوال !!(')

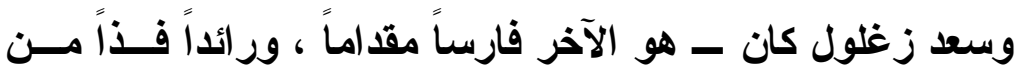
فرسان ورواد الحركة الوطنية فى مصر .. أولئك الذين دعوا مخلصــين

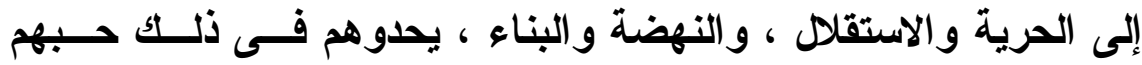
الثديد لمصر- ذلك الأى استقر فى أعماقهم ، وسرى فـى عــروقهم ،

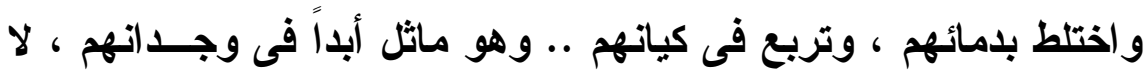

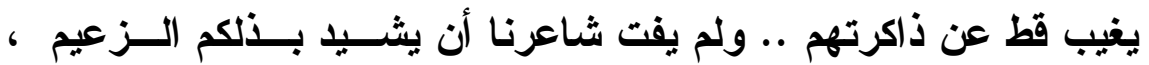

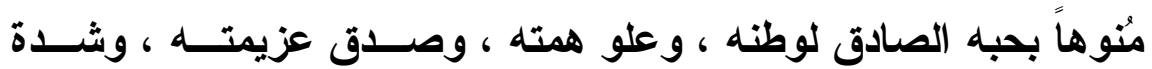
إصراره فى العمل على ما فيه بناء ونهضة وحرية واستقلال بــلاده ...

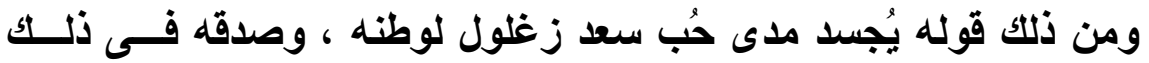
الحُب - الأى ملك عليه كيانه فغذا كل شئ فى حياته ... ومن ثـــ بــات محور اهتمامه ، وجوهر تفكيره ، ومناط شظله ، ومبلغ علمه ، وأكبـر همه :

كم بات مهتماً بمصر وأمسرها

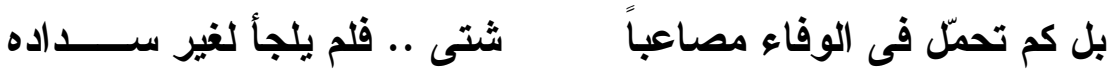

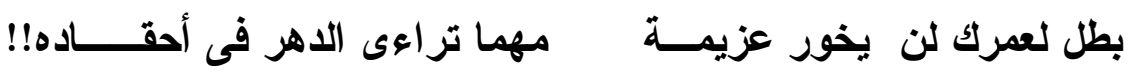
خُلقُ أغز وهمـــــة وعزيـــــمة فى المجد لم تعرف سوى أمجاده(؟) ويناجى شـاعرنا بعد ذلك سعداً فى أثناء سفره من أجل وطنــهـ ،

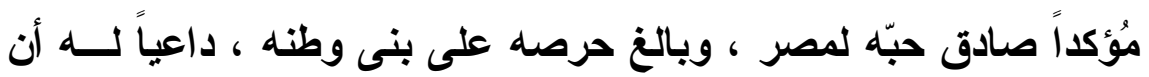

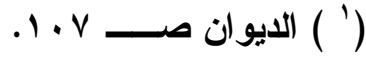

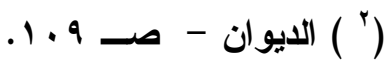


يئوب سالماً ، وأن يبقى دائماً عالي الهمة ، أبي النفس ، قوي العزيمة،

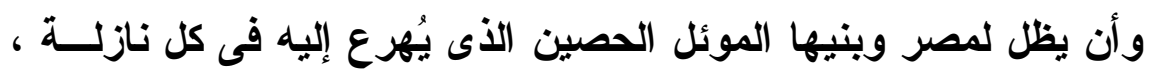
وأن يمده الله بعونه ومدده ، حيث يقول :

مقــــار لوعــته علـــــى أولاده

جهاً بمصر على عظيم جهاده !

ولألت طالع مصر فى إبـــــعاده

وأمدَّك الرحسـمن من إمـــداده!!(1) يا أيها، الثيخ الأى شهد الورى عد للكنانة ســــيداً لـــم ياخر فلألت من يُرجى لكــــل ملمّــة يا سعد دمت لكل مجـــ غــاية والبيت الأول يؤكد من خلاله الثاعر ، وييرز مدى حُب وحنــو وحدب وحرص ذلكم الزعيم إزاء بنى وطنه ، وفى التعبيــر بكلمــة : "

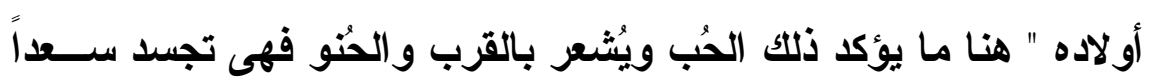

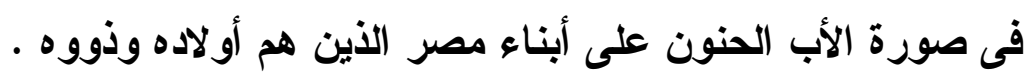
وفى موضع آخر من شعره يُشيد الشـاعر بجهود ذلكــم الــزعيم المخلصة فى المطالبة بالحرية والاستقلال وإيقاظ روح التهضة والتوثب

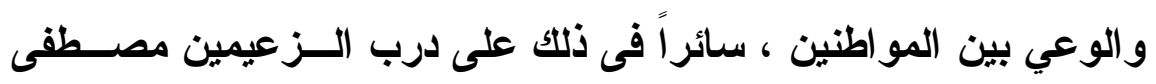

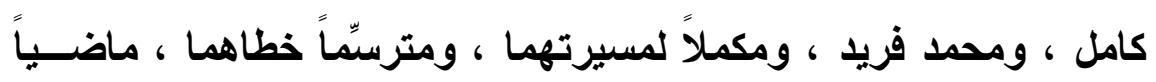
فى ذلك لم يثنه نفي ، ولم يخالطه ارتياب ، ولم يعقه اضطهاد ، بل كــان

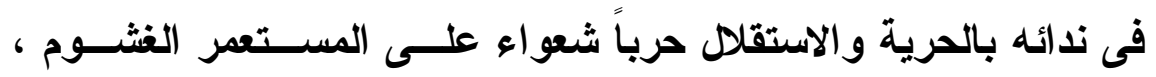
يُفحمه بخطبه الثائرة ، ومقالاته الحماسبة ، وكلماته الملتهبة التى تشثبه

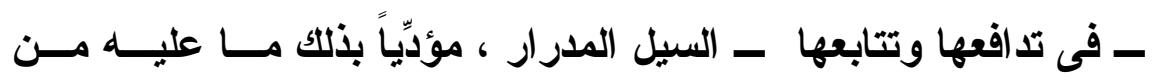


واجب آمن به ، و اعتقد فيه ، وما حُمّل من أمانة ثقيلة أتى إليها راغبـاً

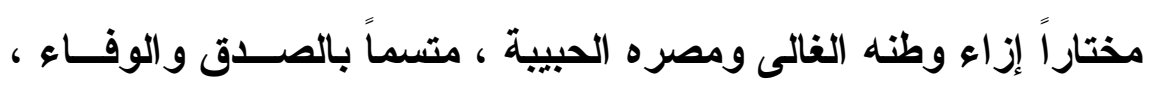

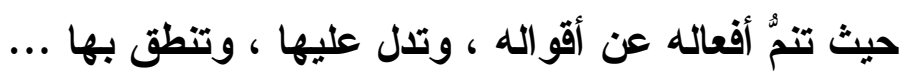
يقول الثناعر :

وفى تاريخه العجب العجـاب

بها الصوت الجهير المستجاب

بها النفس الأبية لا تصــــاب

على صفحاتها عكف الثــباب

له من صادق العزم الركــاب

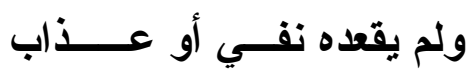

على المستعــرين فلا يُهاب

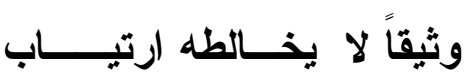

وفى الأعمــــــال إخلاص يُّثاب

فبالإفحام يحضره الجــــــواب

شبيه السيل يدفعه الخطــاب

بحقٍ دونه تمضى الرق

له فى الله والوطن احتســاب
كنلك كان سعد فهو حســـ أقام لمصر مئذنة يـــدوّى وعلَّمها الطموح إلى حيــاة ولقتها الكرامسـة فى دروس وكان شبيه صاحبه عر ابـي وتابع كاملاً وحذا فريــــــاً ونادي بالجلاء وكان حسرباً لمست وفاءه فلمســت عهثاً وأعجبنى به فى القول صدق إذا المحتل راوغ فى سؤال و إن صعد المنابر فهو فيها تقدم باسم أمته يُنــــــــادى لئر فكان على أماتته حريصـاً 
تُوكَّ أمسامه الثمّم الصّـــلاب (1) وفى إيمانهـ بالحــق عــزم

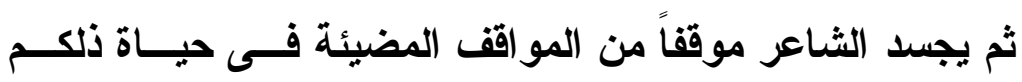

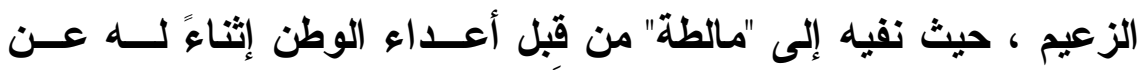
مبئيه ، ووقوفاً فى وجهه ، كى يتحول عن مواقفه ، ويرجع عن مطالبه

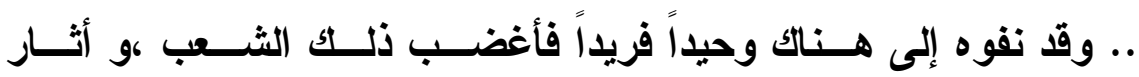
حفيظته ، فثار ثورته ، وغضب غضبته ، فراح ينادى بعودة فارســه ،

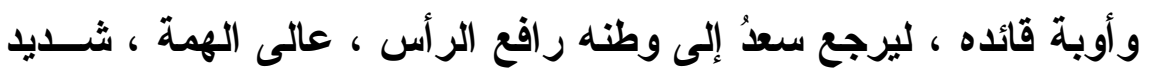

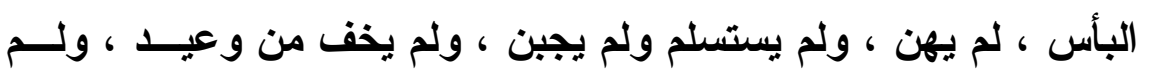
يرهب من منية ، و إنما عاد أقوى مما كان يمضى فى تحقيق مطالب بنى

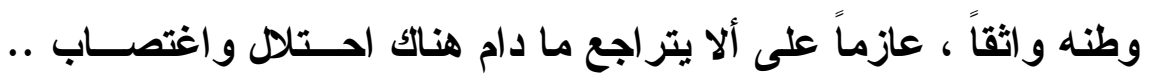

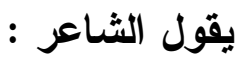

له ظقر يغــــير به ونــــــاب ولا أهل هi هـــــاك و لا صحاب بعودته وكــان لله الغــــلاب

فثـع النور واتقشــع الضباب وجدّ بهـ لغـــايته الطــــلاب ولم يأخذه فى الحق العتــاب ولم ترهبه إن شرعت حراب

ولا يبقى احتلال واغتصاب!! (1) ففى ( مالطة ) وغول النفى فيها فقيها كان محتســـــــــاً رهيناً فثار الشعب ثـــورته ونــــــادى

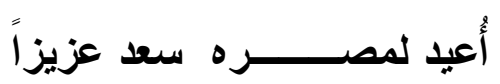
فلم يركن إلى خور وضـــــــف ولا خاف الوعـيـ والمنـــــايا وجدد سعيه لم يخش ســـنا

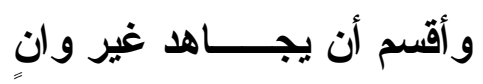


وحافظ إبراهيم ـ شاعر النيل ، وترجمان الثعب ، ولسان حسل

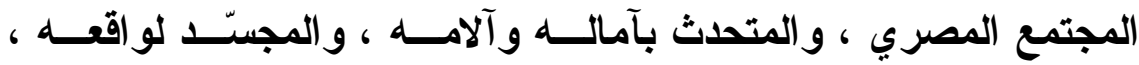

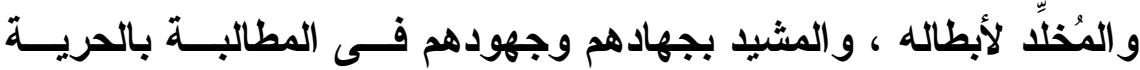
و الاستقلال ، والاعوة إلى اليقظة والنضال .. ذلكم الثـــاعر كــان لــه

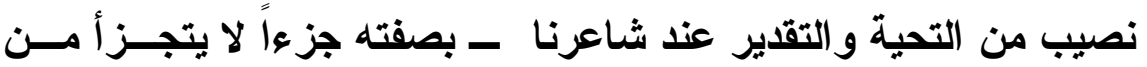
الوطنيين المخلصين فى عصره ؛ بما أسهم به فى شعره فى إذكاء روح الوطنية فى نفوس بنى وطنه ، وبث روح اليقظــة والــوعي بيــنهم...

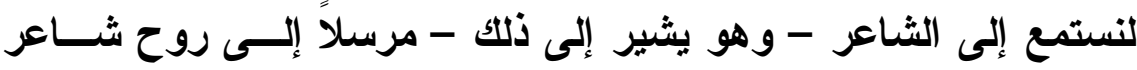

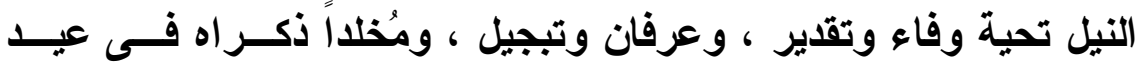

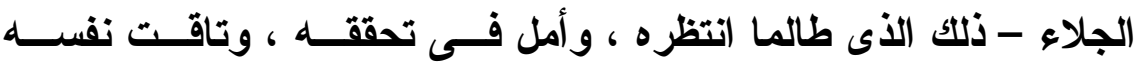
لحدوثه ... يقول الثناعر :

دفعت بنا للثورة البيضـــــاء

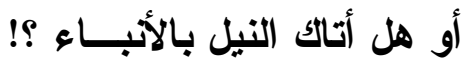

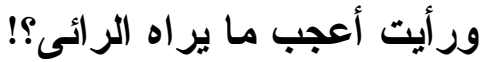

حيث الحياة كما اثتتهيت وفوق ما صورت من مُتل ومن آراء (†) ثم يوقفنا الثـاعر بعد ذلك على جانب مضئ من جوانــب شــعر

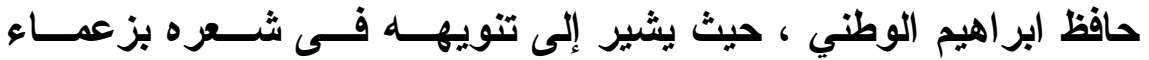

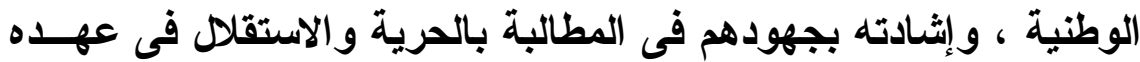

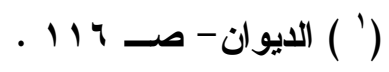

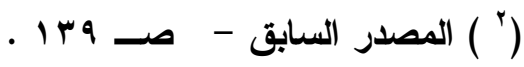




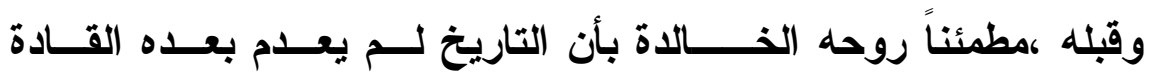

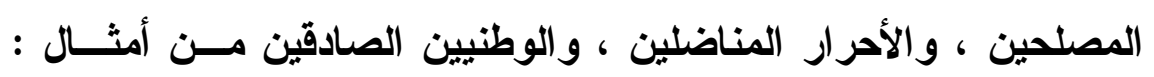

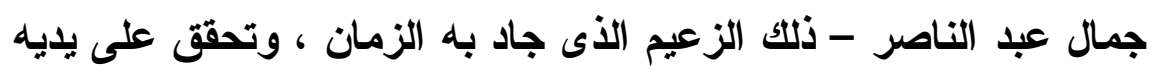
للوطـن النصر والفخار ، يقول : أطريت همّة (مصطفى) ومضاءه و إلى (فريد) سقت خير ثناء وبحبّ (سعد)كم شدوت وكم جرت للك مدحة كالآّرة العصدــــاء ماذا أقــــول إذن إذا مــا جئتنا ورأيت كيف مواقف الخلصاء (فجمال عبد الناصر) ازدانت به كتب الوفاء وصفحة الزعماء

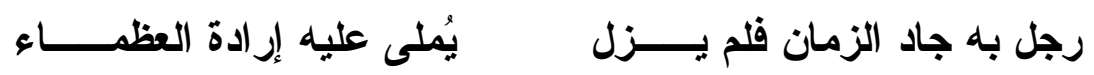

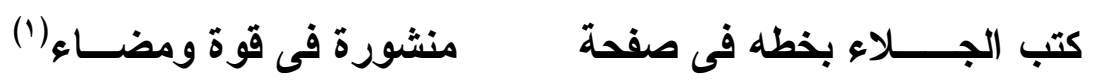

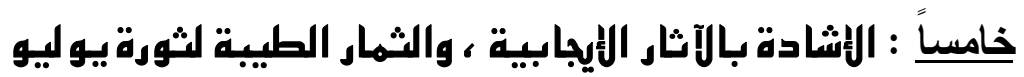
، وإبراز صداها على بنى الوطن آنئذِ.

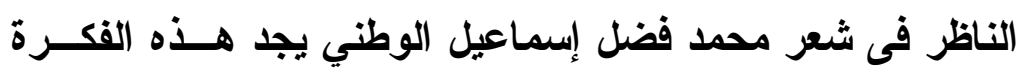

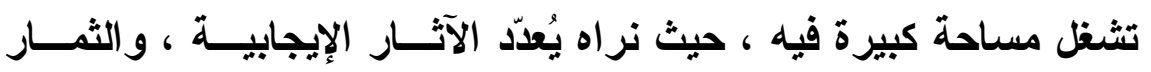

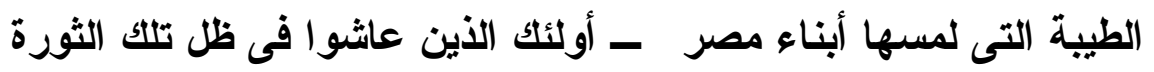

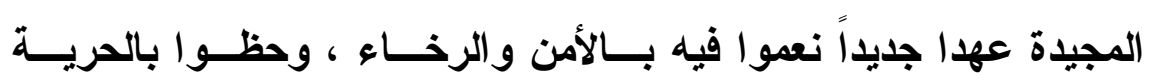

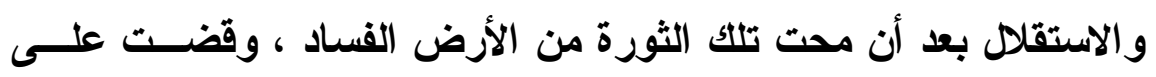

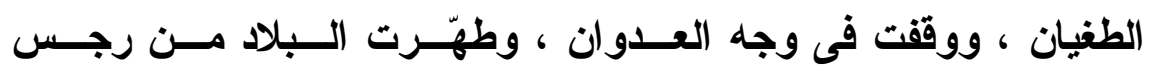

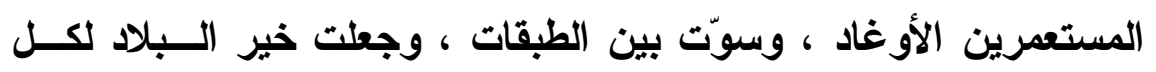


العباد ، فلا راس مالية ، ولا إقطاع .. وعمّ بها فى الأرجـاء النهضــة

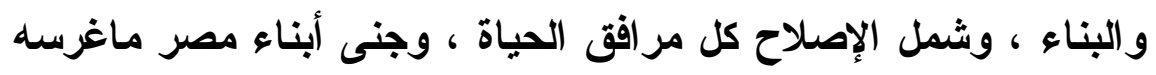

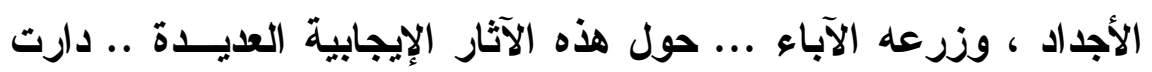

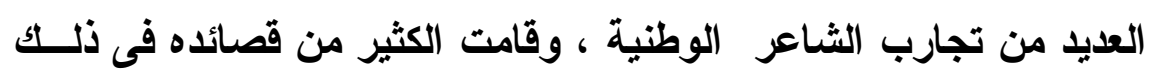

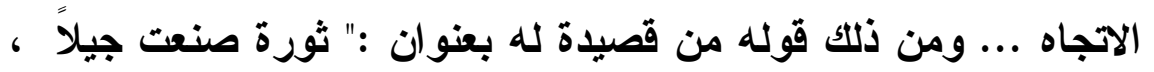

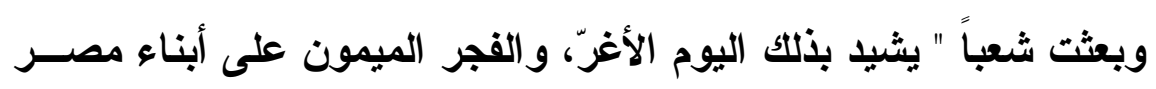

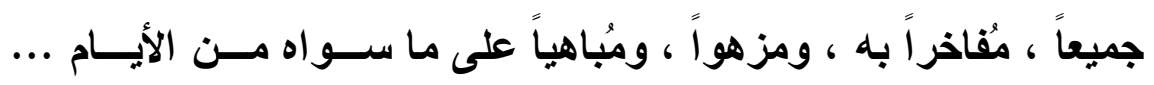

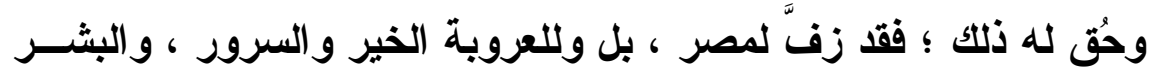

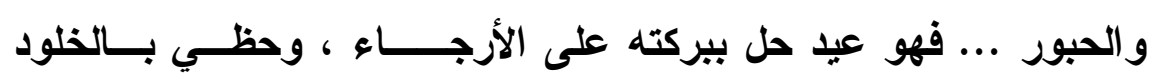

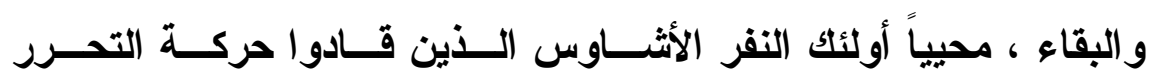

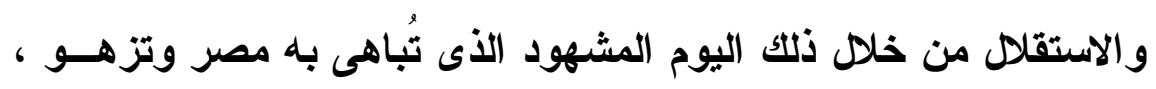

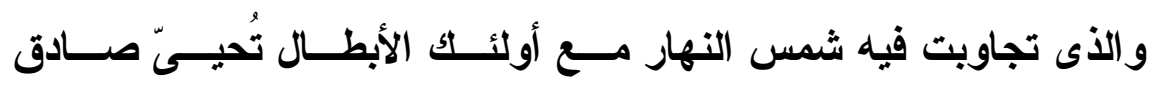

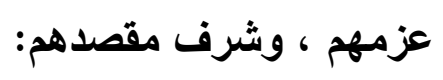
سل الثلاثة والعشــــرين عن أمم ما زف يوليو لوادى النيل والهرم!! سل غُرّة الصبح عن يوم به طلعت شمس النهار تُحيّّ صادق الهمم!؛

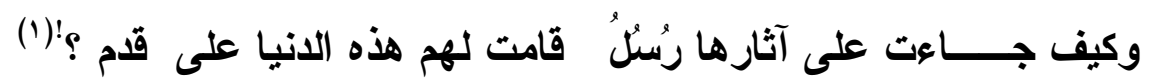

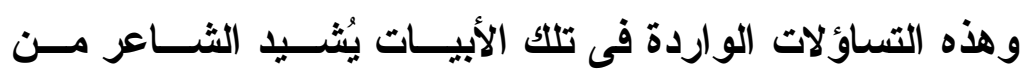
خلاها، ويتغنى بذلك اليوم المشرق ، والصباح المضئ الذى تنفسيّ فيه

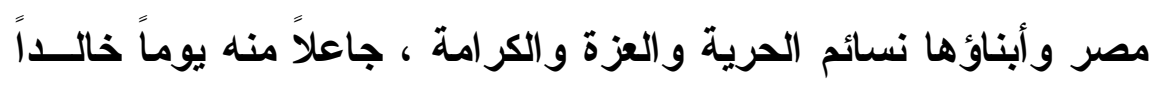

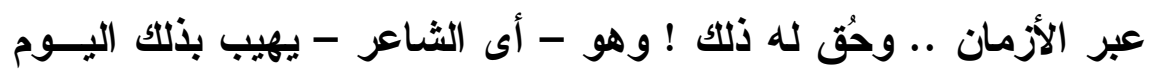


أن يزهو ويفاخر فيُداخله الفخار والسرور ، وتتنابه الفرحة والحبور ... فهو نسيج وحده بين الأيـام ،فقد زفّ لمصر وأبنائها الفرحسـة والســرور .... وأعاد لهما الكرامة والشموخ .. وتلكت التساؤلات وردت على سبيل المجاز .. حيث جعل الثاعر من ذلك اليوم عاقلاً يُسائله ، ويــردّ عليــهـ

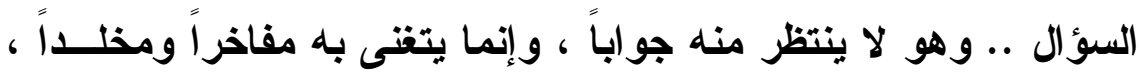

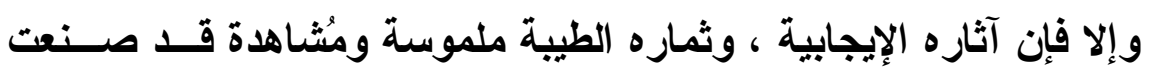

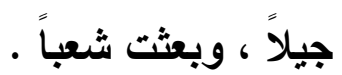

وبعد أن تغنى الثـاعر بيوم الثالث والعشرين من يوليو ، وبعـد

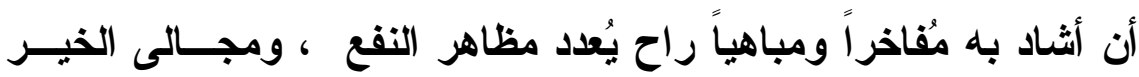
التى أفاد منها أبناء مصر ، ونعمو ا بها فى ظل تلك الثورة العظيمة . ومن ذلك ما أثنار إليه - خلا الأبيات التالية - حيث يؤكد كيف أن تلكك الثورة قد محت الفساد ، وقضت على الطغيــان وهـــــت دولـــة الظلم ، بعد أن عزم أبناء الوطن الثرفاء على طرد الملـــــ " فـــاروق " رمز الطغيان - مُظهرين أمامه بأسهم الثديا ، وعزمهم الأكيد ، ليبـــأ عهر جديد - هو عهز الحرية والاستقلال، والعدالة والاستقرار ... يقــول الشاعر :

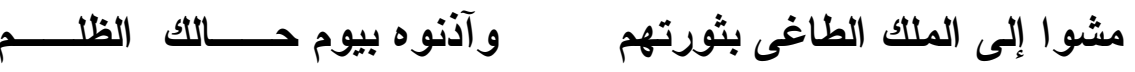
وعلّموه دروساً كان يجها ومزّقوا ذلك العرش الذى نصبت فيه المقادير تمثـــالاً من الصنم 
ودولة الظلم مُنهار جوانبــــها وإن يطل عهدها المشئوم لم يدم(1) وعن المساوة بين طبقات الشعب ، و إلغاء الرُّتـبـ والألة ابــاب ،

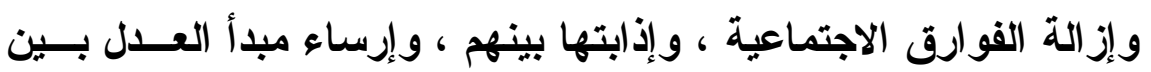

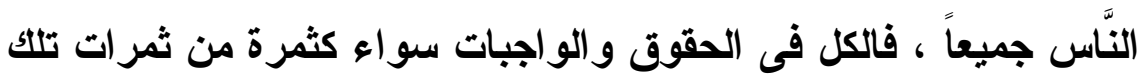

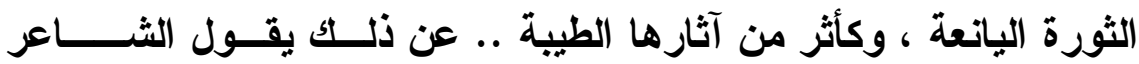
متغنياً :

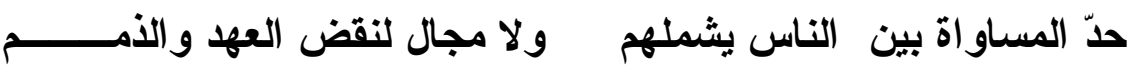
وما هنالك ألقـــــــاب تميزهــــم ولا سبيل لوضع غير منســـــــم

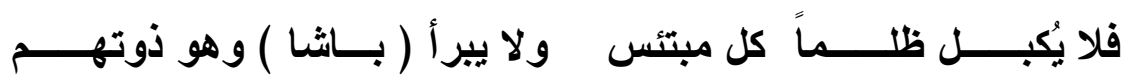
ولا ترى حافياً فى الأرض يذرعها ويركب( الكاديلاك ) الفخم ذو اللخم هذى الفوارق قد ذابت صلابتــها كما يذوب سبيل التبر فى الضــرم فحامل الفأس فى الوادى لله صفة كحامل السيف والصمصامة الخذم(؟) وما أدق تعبير الشاعر، وما أبلغ تصويره فى الحديث عن إذابــة الفوارق بين الطبقات كثمرة من ثمار تلكم الثورة المباركــة ... حيــث

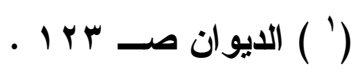

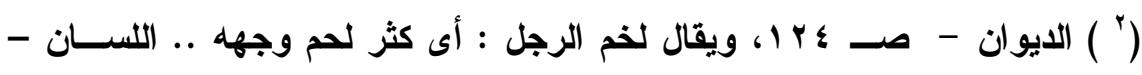

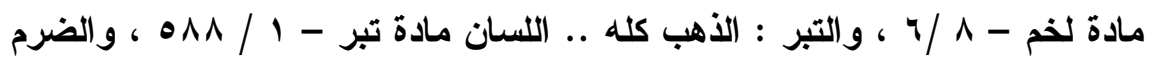

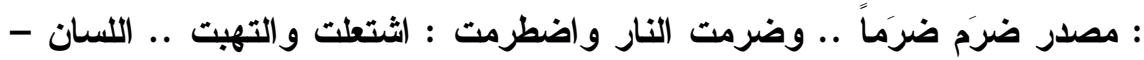

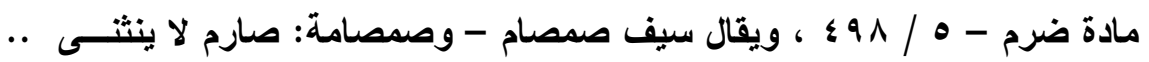

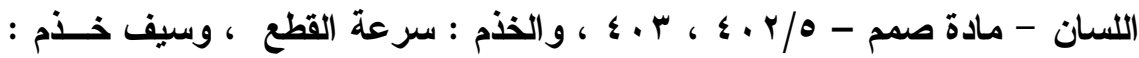

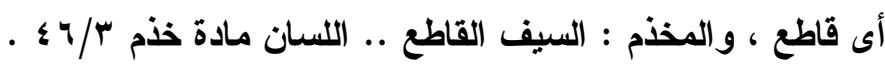


استعان فى إبراز ذلك المضمون - كما نرى بالتثبيه الرائع البليغ الــنى

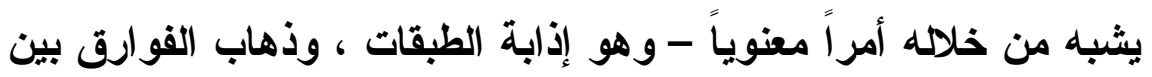

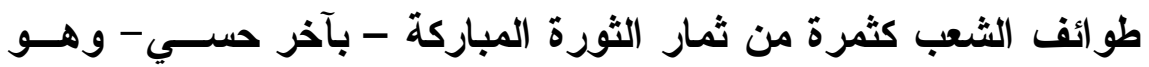

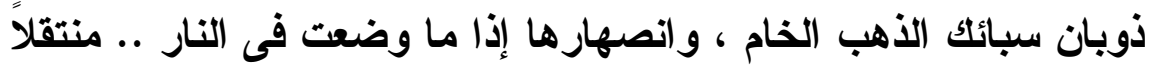

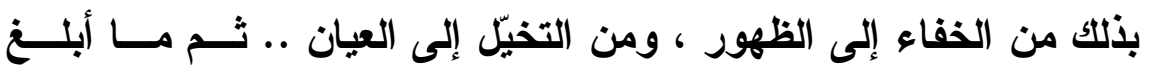

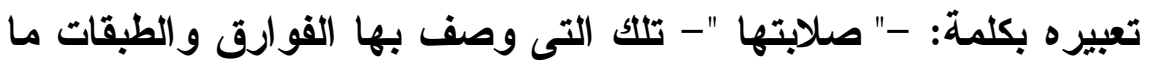
أبلغه من تعبير هنا ، وما أدله على المضمون ، حيث يؤكد كيف أن ذلك

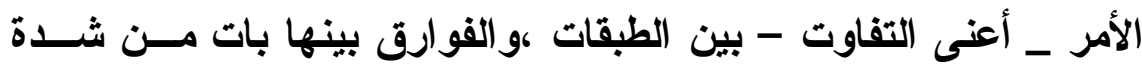

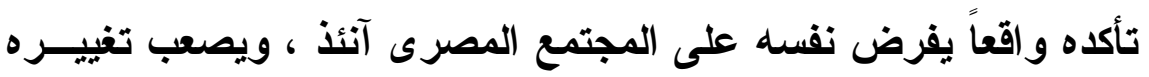

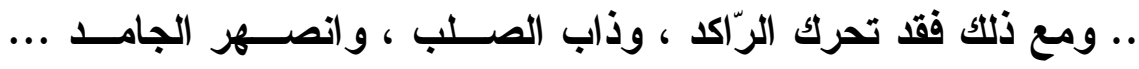

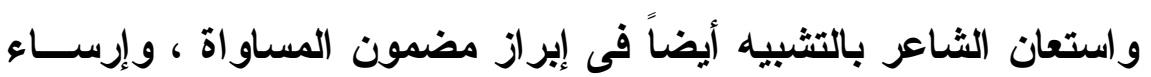

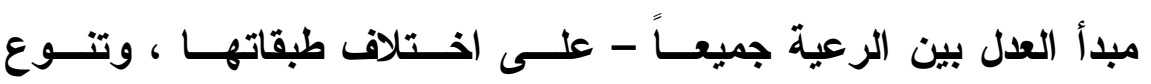
مستوياتها .. حيث يقول: فحامل الفأس فى الو ادى له صفة كحامل العيف و الصمصامة الخذم ويؤكد الثـاعر ذلتك الأثر الإيجابي البارز من آثار تلكـــم الثــورة

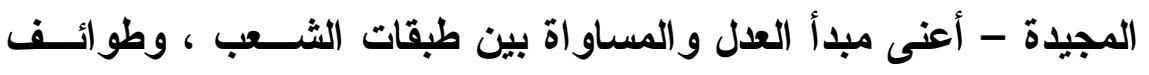
الوطن - بعد ما ذابت الفوارق بينهم ، وتلاشت . . ها هــو ذا الثـــاعر

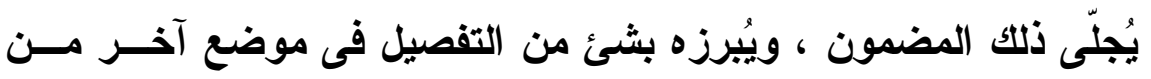

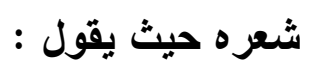

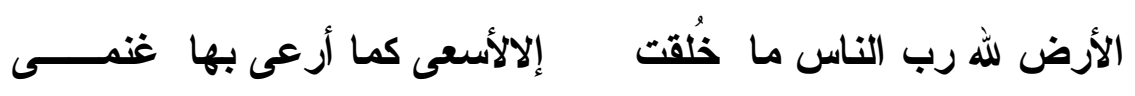

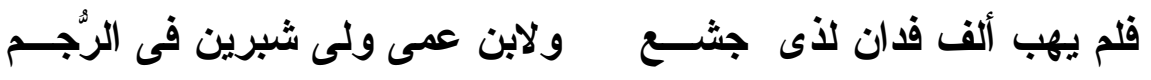

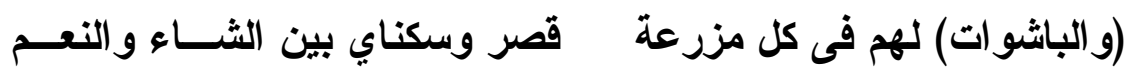




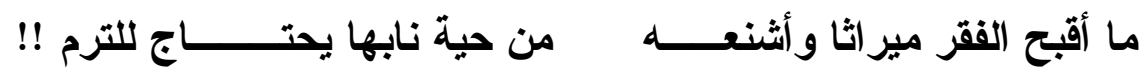

فلا احتكار ولا استغـــلـل بعدئذٍ ولا اعتبار لر أس المال فى القيم (')

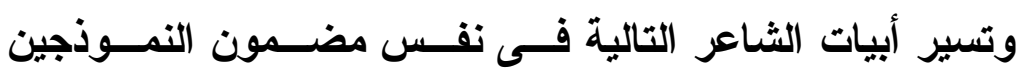
السابقين ، حيث يؤكد الثاعر -خلالها- تحقق مبدأ العدل والمســاواة ،

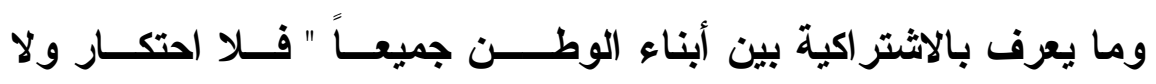

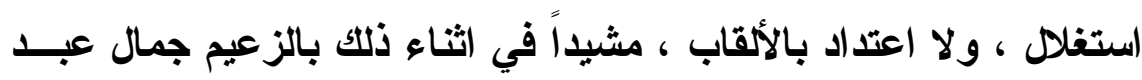

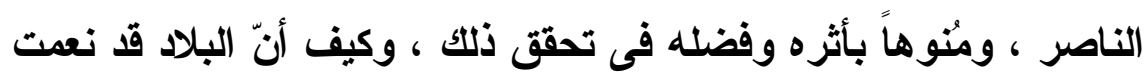
فى ظل حكمته ، وحُسن سياسته ، وسداد رأيه ، ورجاحة عقله بـــالخير الوفير ، و الخصب العميم ، حيث يقول :

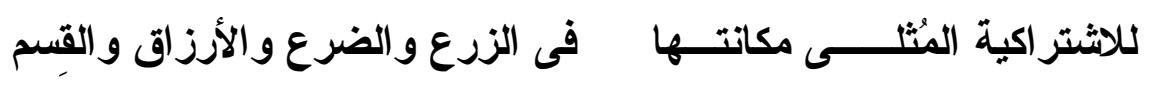

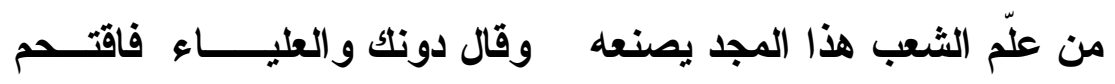

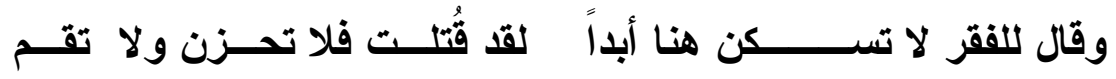
هذا لعمرك (عبد الناصر) اكتملت له المواهب من رأي ومن حكم!(ז) وكان من بين ثمرات ثورة يوليو الياتعة ، ومن بين إيجابياتهــا

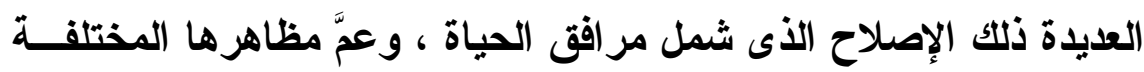

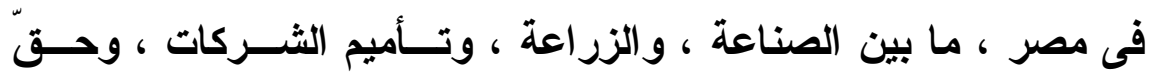
العامل فى الخير الذى تصنعه يده وغير ذلك ... وشـاعرنا - وهــو (بـنُ

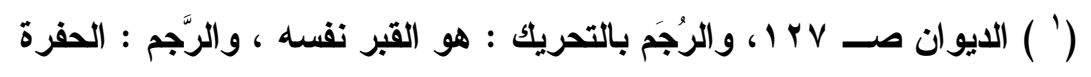

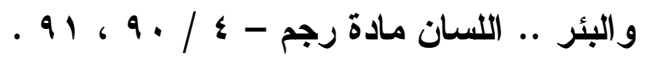

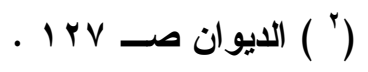


من أبناء الوطن الذين لمسوا ذلك الإصلاح الذى شمل كل تلك المرافـق

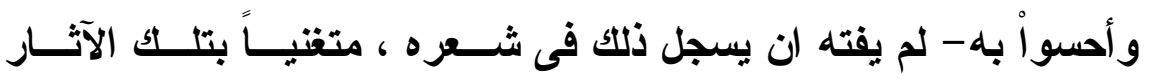

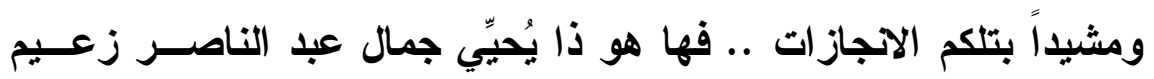

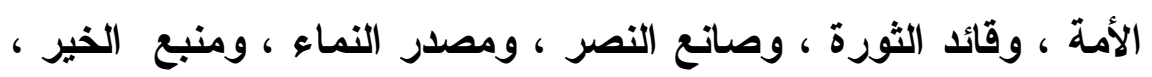

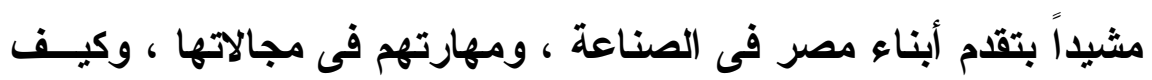

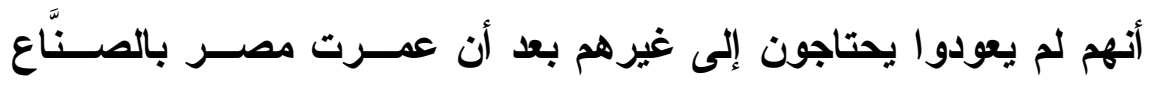

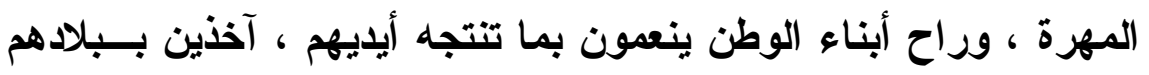

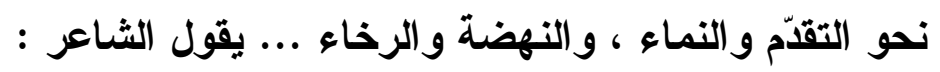
رعى الإله (جمالاً) فهــــو عُدتنا عند الخطوب وعند الحادث العمم لقد كفانا ضياع المــــال تخطفه أيدى الفرنجة من روم ومن عجم كاتت وسيلتهم لسلب ما زعموا من الصنـــــاعة كالأزرار والحزم

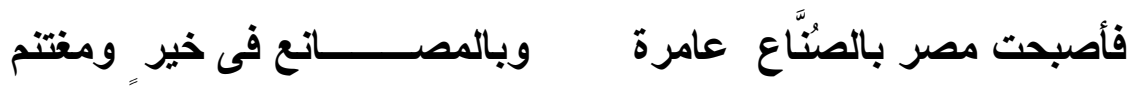

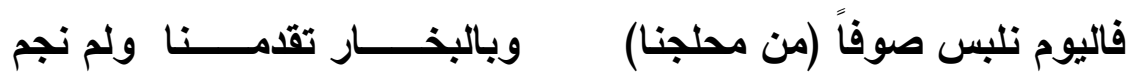

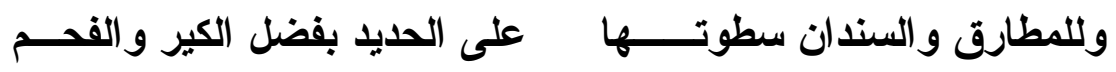

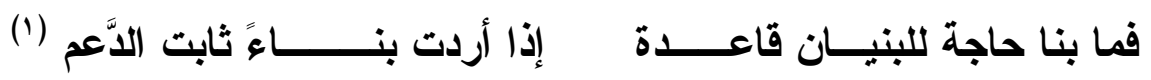

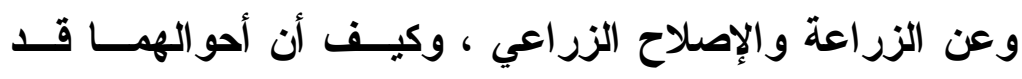

صلحت وانتعشت آنثذٍ ـ بفضل تلك الثورة العظيمة.. يقول الثناعر :

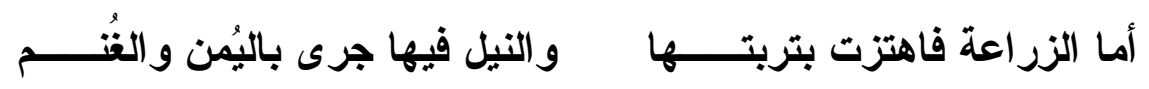


للقطن فيها شجيرات حوت ذهباً: فيى فضة لسداها أكرم اللحـ و العب ذو العصف والريحان منتثر فى كل حقل بنور الزهر مبتـسم قد هذبتها يد الإصلاح فابتعـدت عمّا يشين فلم توصم ولن تصــم و الأرض زادت بل امتدت مساحتها من فيض ربك بارى الخلق و النَّم

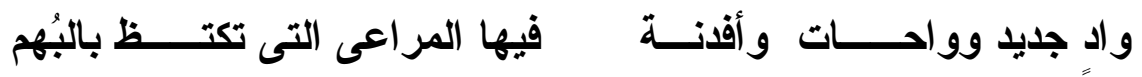

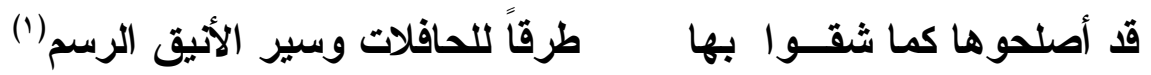
وقد جسد الثـاعر ذللك الجاتب المضــئ مــن جوانسب الثــورة

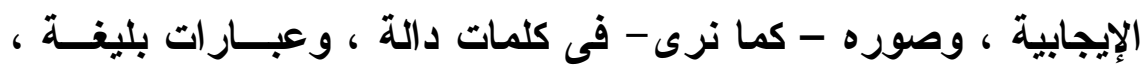

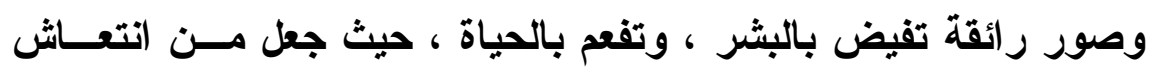

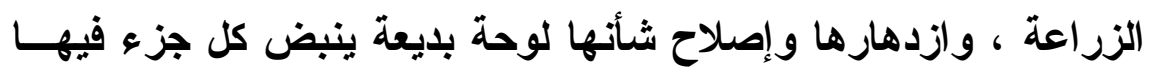

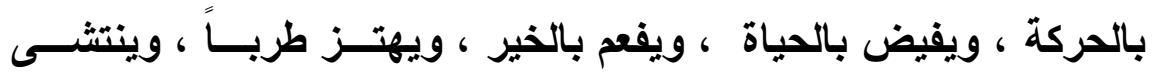

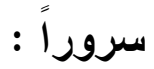

أما الزراعة فاهتـزت بتربتـــــــها و النيل جرى فيها باليمن والغتم والحب ذو العصف والريحان منتشر فى كل حقل بنور الزهر مبتسم

(' ) الايوان - صـ 1 ب ا ، و الموضع نفسه ، و العصف :ورق مالا يُؤكل منه : أما

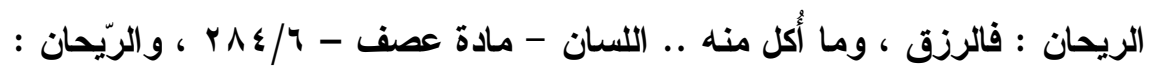

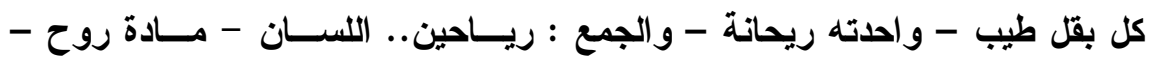

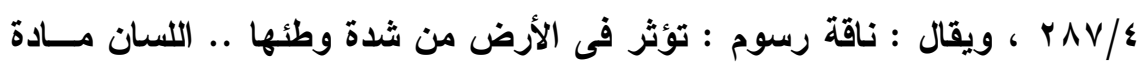

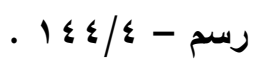


حيث توفر فى هذه اللوحة الرائقة من معالم الحسن ، ومظــاهر

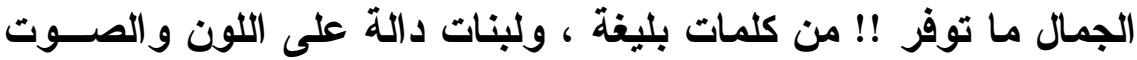
و الحركة .. بحيث استحال كل جزء فيها إلى كائن حي ينبض بالحركسـة ،

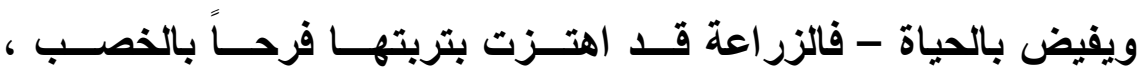

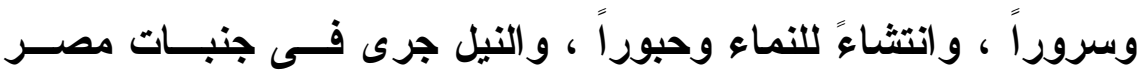

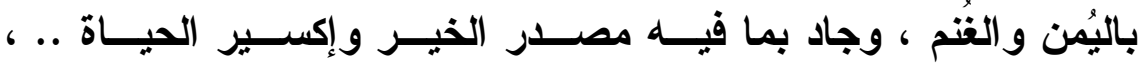
وشجيرات القطن قـ استحالت ذهباً وفضة بعد أن استوت على ســوقها ، فجادت بالخير ، وفاضت بالنماء ، و الحُب ذو العصف و الريحان منتثـر

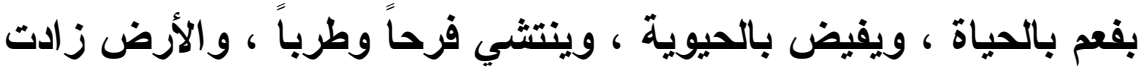

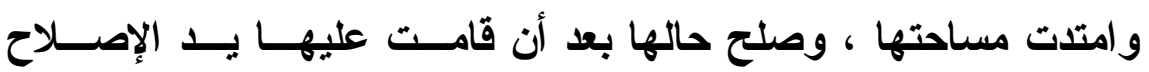
بالتهذيب و الرعاية ، و التقويم والعناية .

وعن تأميم الثركات ، وكيف أن العُمال بها باتو اينعـــون بــــا

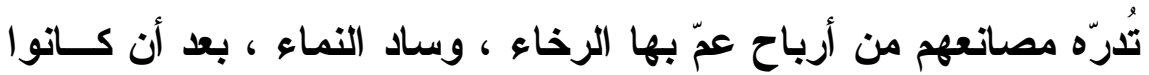

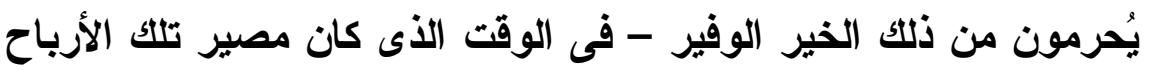

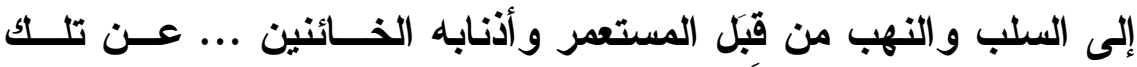
الثمرة الطيبة من ثمار ثورة يوليو المجيدة بقول الثاعر : كم من مؤسسة كاتت هنا شركاً لللبل و النهب لم ترحم ذوى الألم وكم بلت شركات كان معظمها على المرافق و العمــــال كالحمم قد أصبح الريع من أرباحها هبة تجزى الأجير بما لاقى من الغـرم من أجل هذا نما الإتتاج فى بلدٍ فالحمد لله قـ زالــت متاعبــنا وما بنا من جوى فى الصدر مضطرم 
إذ نال عاملنا ما ضاع من يده وما هــــالك من وجه لمختصم

وأصبحت مصر للمصري يملكها لاللانى اكتـــــال أموالاً بلارقم (')

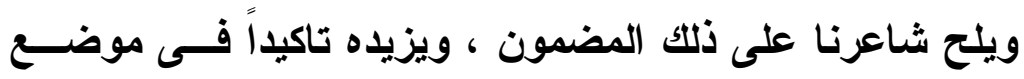

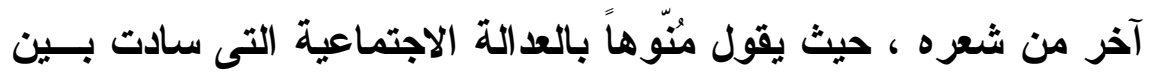

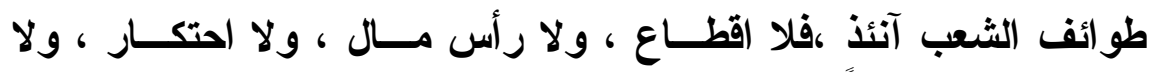
استئثار بالخير لطائفة دون أخرى :

وسوس الثيطان فيها بالنقود!!

وانتهى ما كان من أمر الرصيد

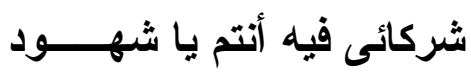

يتهادى فى طريســــف أو تليل

لم يذق فى دهره طعم الثـريد

ليس فينا من إماء أو عبيـــ

فى المساواة اتجاه للزلـــود (†) يالر أس المال من أضدوكة إن عهد الر أســـمالى انقضى كل بنك هاهنا بنكسى أنـــــا ليس فينا اليوم من ذى ثروة حوله الجوعان والعارى ومن انتهى الإقطاع و الظلم انقضى إنما فينا اشــــتر الك حكمــهـ

ويا لها من سخرية لاذعة ، وما أقساهُ من تهكم مرير هنــا !! ،

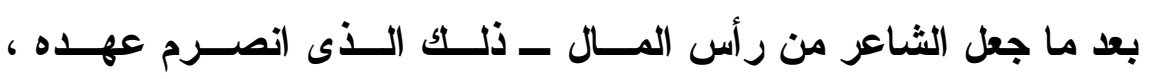

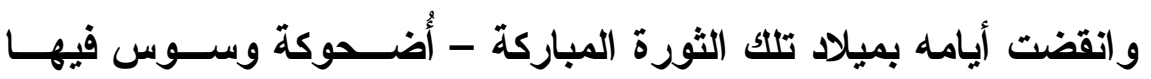

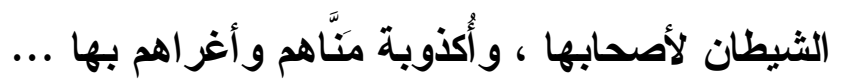

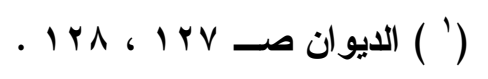

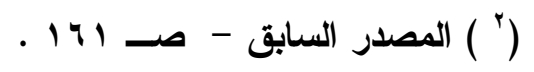




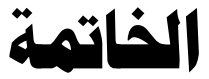

الحمد لله الأي بنعمته تتم الصالحات ، ويحوله وطَوَـــهـ تُقضــى

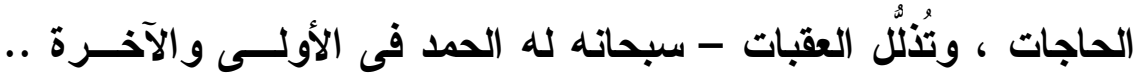

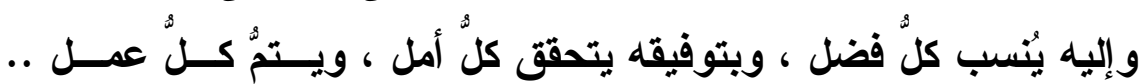

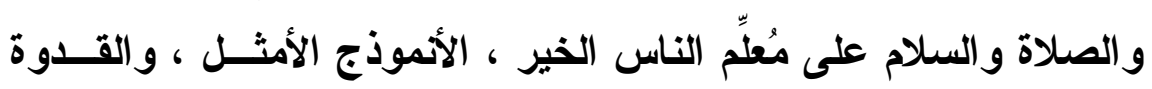

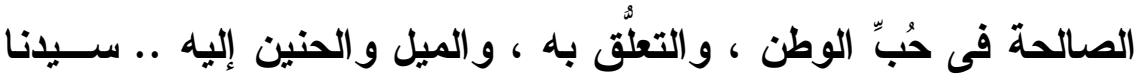
محمد

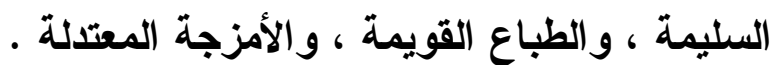
وبعد

فها ندن أولاء قد وصلنا ـ بفضل الله وبتوفيقه ــ إلــى نهايــة المطاف فى تلك الرحلة التى جُبنا خلاها جانباً ابداعيا متميزاً ، و واتجاهاً

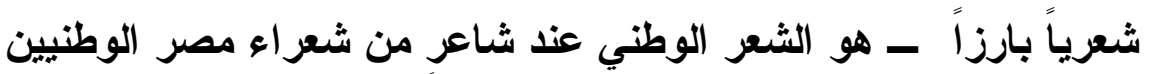

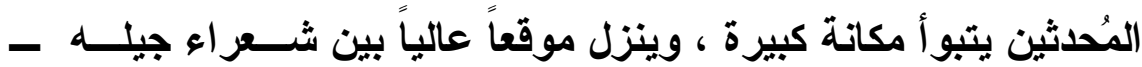
ذلكم هو الثـاعر محمد فضل إسماعيل - و الذى عُـرف بثــــة حُبـهـه ،

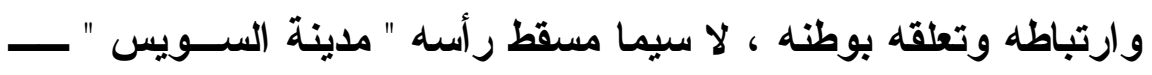
تلك المدينة التى عُرف الثاعر بها،ودُعي ونُسب اليها ، فقيل عنــه : "

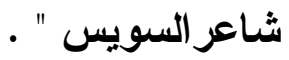

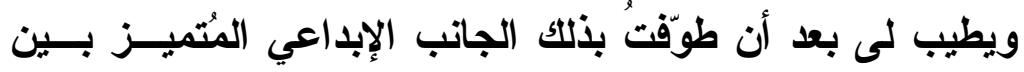

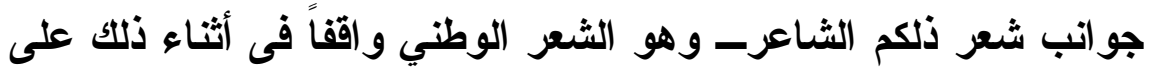

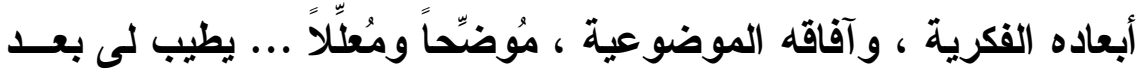
تلك السياحة فى عالم الثـاعر الوطني ، وذلك التجــوال بــين أبعـــــاده 


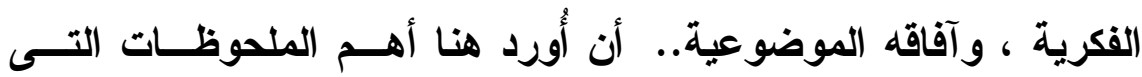

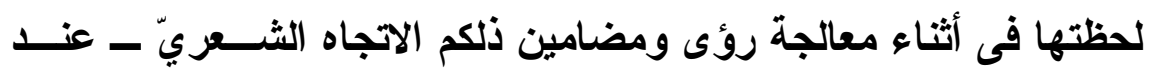

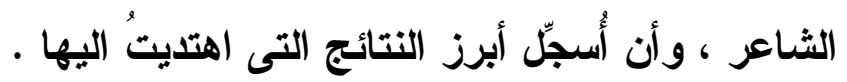
وتتمثل تلك الملحوظات فيما يلى :

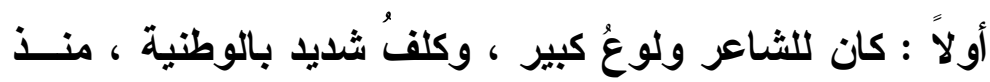

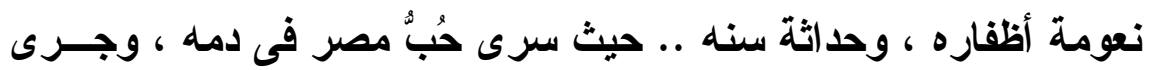

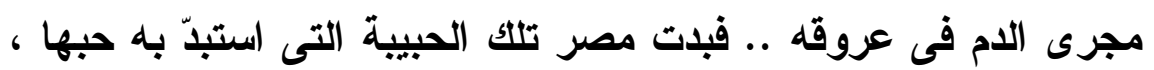

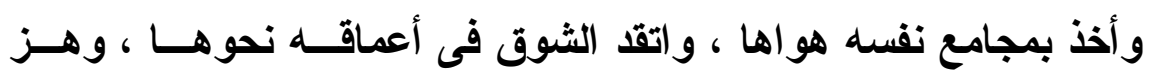

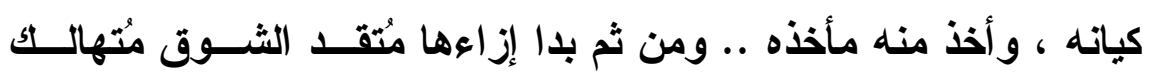

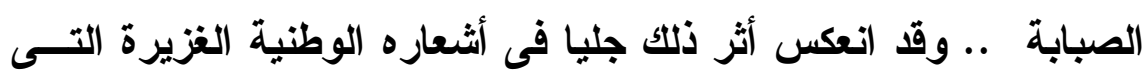
تتقل حماسة ، وتلتهب حمية .

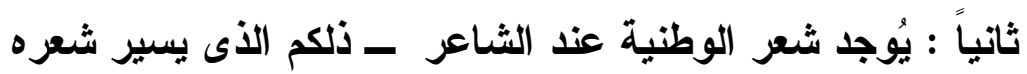

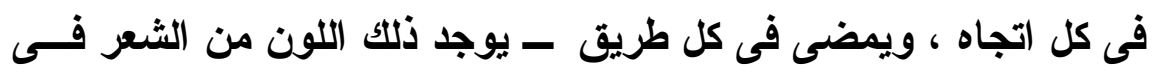

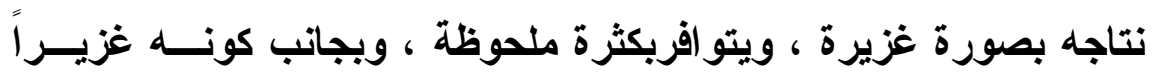

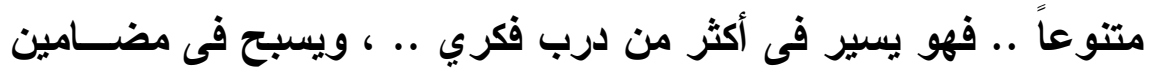

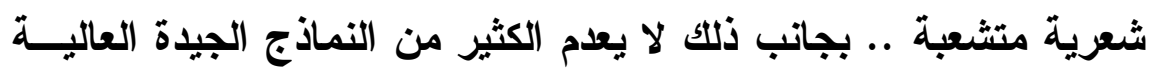

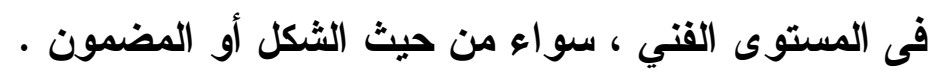

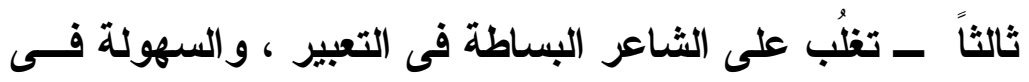

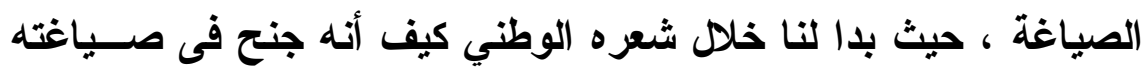

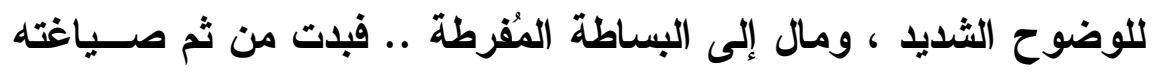

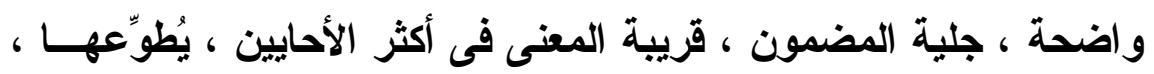

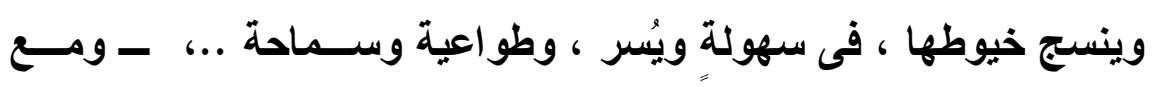


وضوحها الثديد - إلا أنها لم تصل إلى حدٍ السذاجة ، أو تهو إلى درك

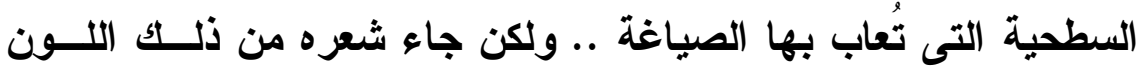

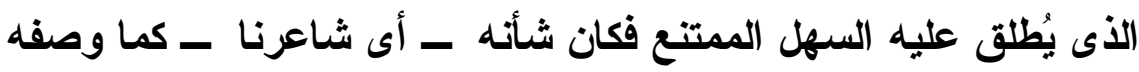

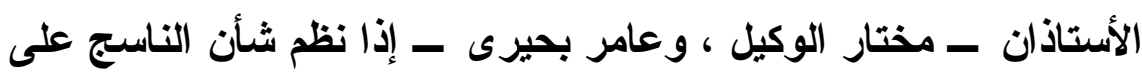

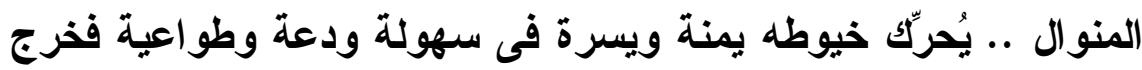
من ذلك الشعر اليسير السهل الذى يُخيّل لبعض القارئين أنه من الســـهل

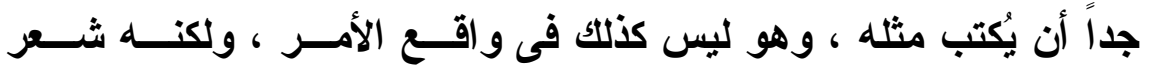

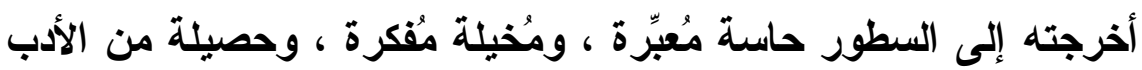

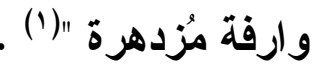

رابعاً : استطاع الثاعر - من خلا شعره الوطني الغزير الجيد

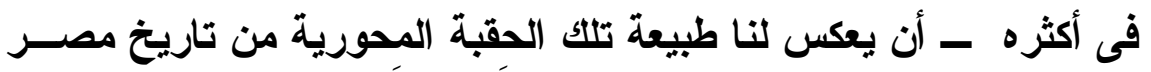

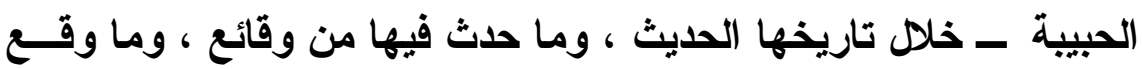

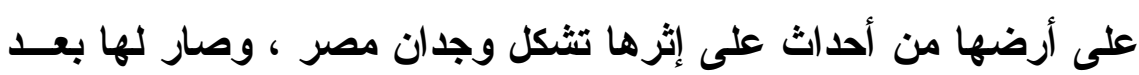

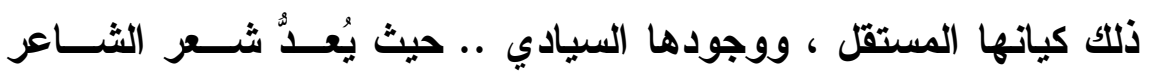

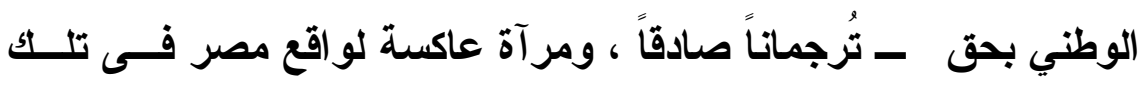
الفترة الزمنية المعنية بالدراسة هنا .

خامساً ـ يظلب على الثاعر خلا شعره الوطني الغزير الصوت

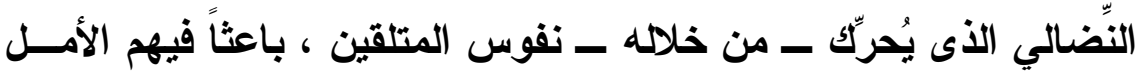

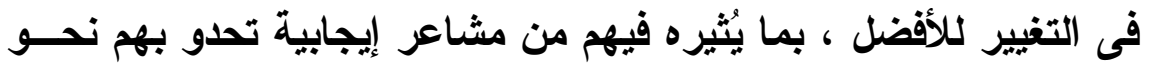

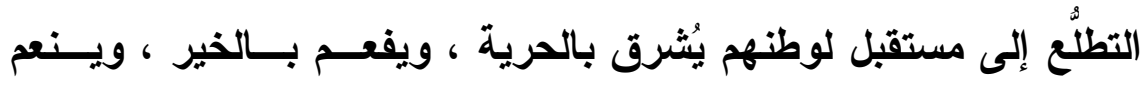

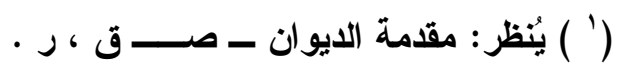




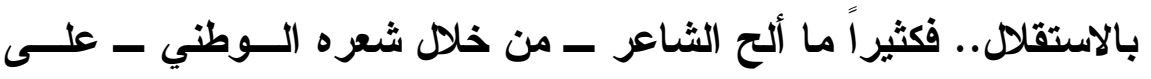

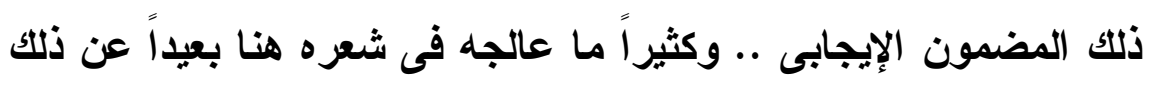

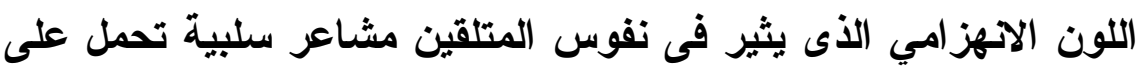

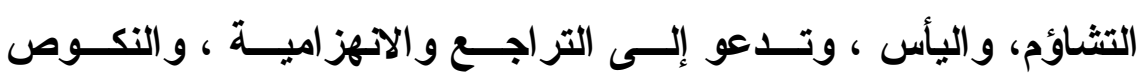
والاستسلام .. حيث كان ممن ينظر إلى الثُعر تلكك النظــرة المثاليــة -

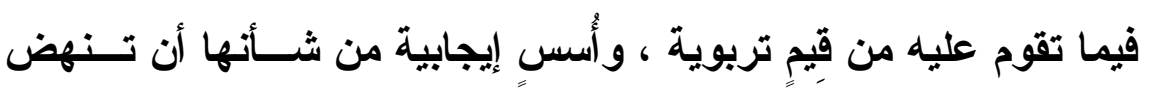

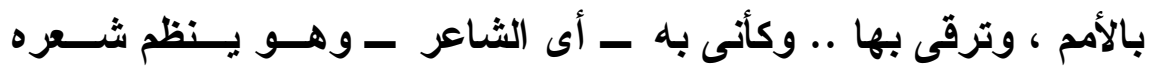

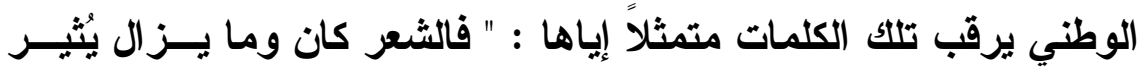

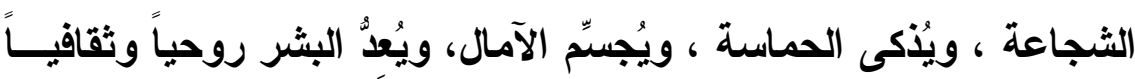

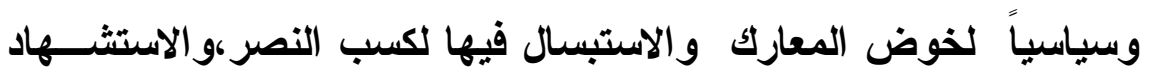

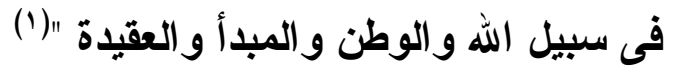

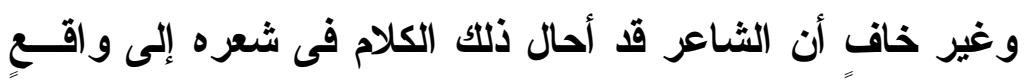

عملي تصدع به كلماته ، و تجهر عبار اته .. حيث يقول :

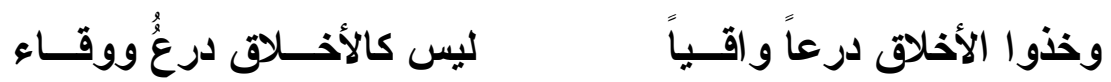

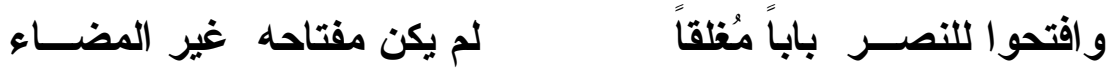

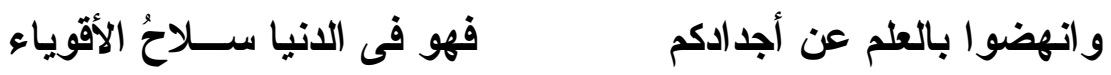

وخذوا الأخـلاق درعاً واقياً ليس كالأخـــلاق درع ووقاء

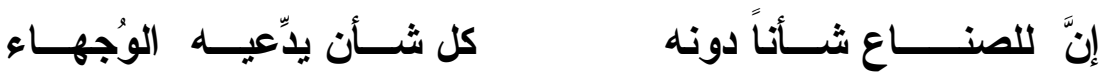

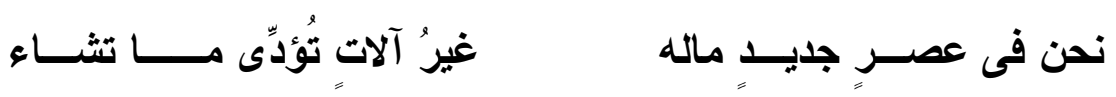

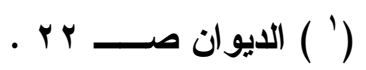




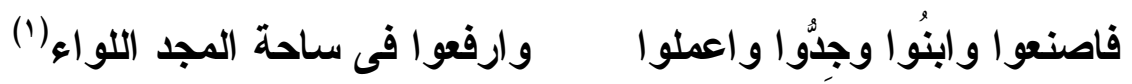
ويقول : حدِّث يراعى عن الأخلاق والأدب وادعُ الشهامة وارفع راية العـرب و اقرأ أعلى هذه الانيا رسالتنا واضرب على الجهل بالأسداد والحُجُب

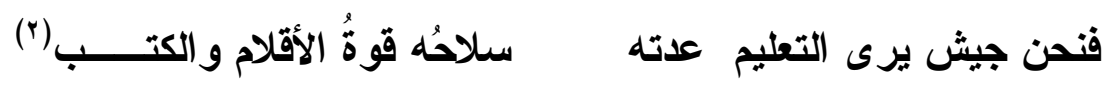
ويقول :

ومن الثقافة خذ سلاحك واعـبِر هذى الحياة هي الجهاد فثـــمِّ

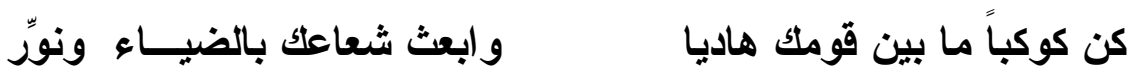

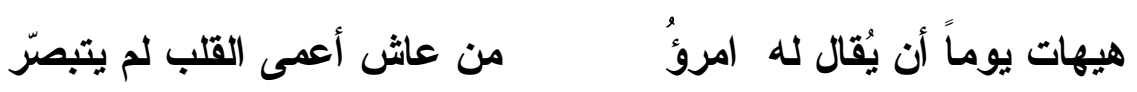

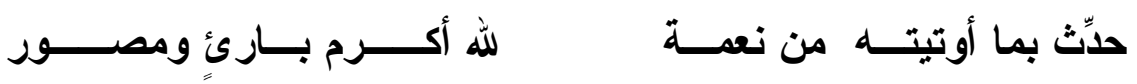
برِّهن على العقل الأى أُودعته بالوعي وانظر للحقيقة واشعُر إذ إنَّ من يمشى مُكبّاً وجــهـه

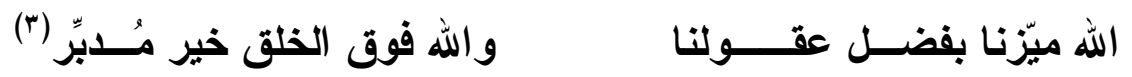
.إلى غير ذلك من النصوص التى مــن شــــها أن ثُثـــر فـى

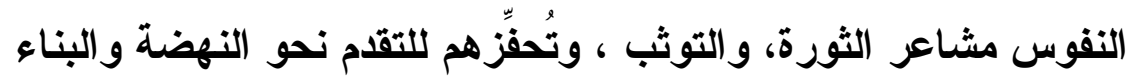

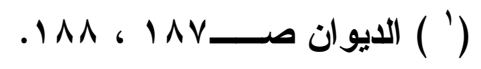

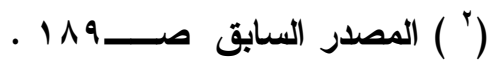

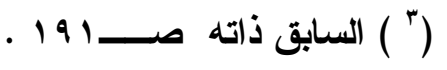


سادسأ ــ اتسمت أفكار الثاعر ، واتسمت مضــامينه - خــله

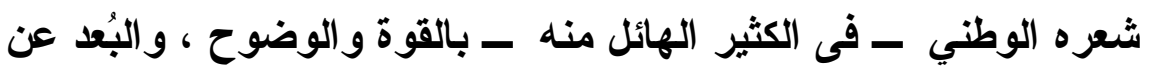

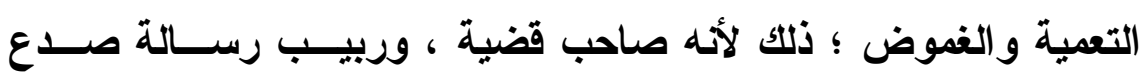

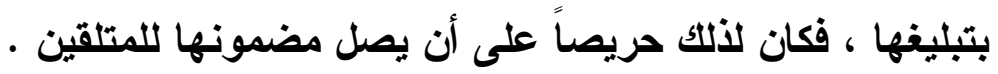

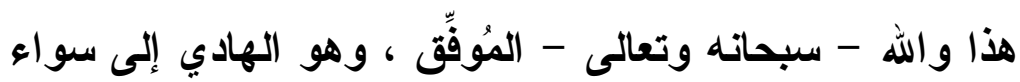

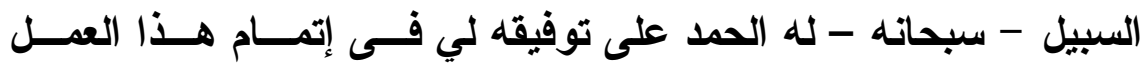

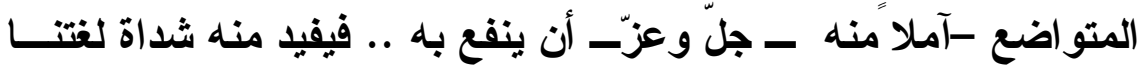

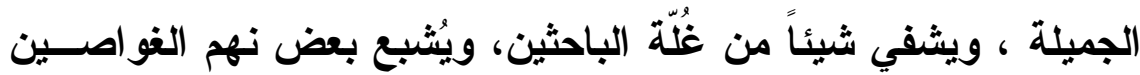

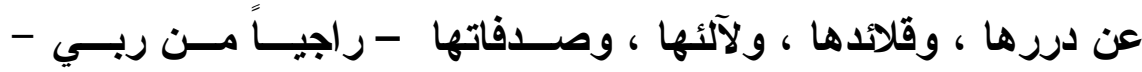

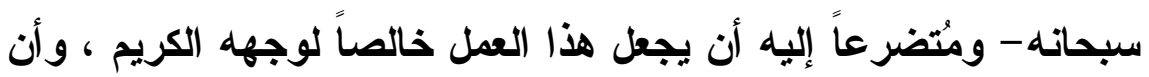
يكون فى ميزان حسناتى يوم الدين - يوم يقوم الناس لربِّ العالمين .

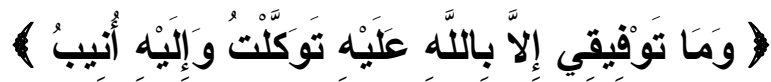




\section{ثبت بهصادر الدراسة وهراجعها \\ القرآن الكريم - كلام الله ربِّ العلامين}

• ديوان محمد فضل إسماعيل ـ شاعر السويس - جمع الأستاذ :

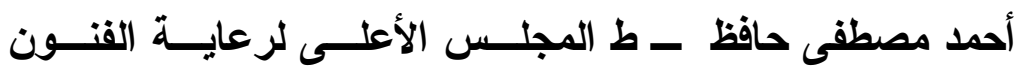

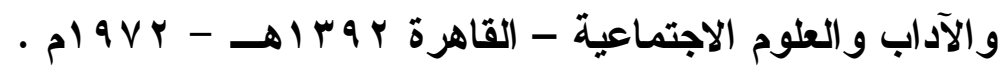

رسائل الجاحظ - تحقيق عبد السلام هارون - ط مكتبة الخانجى

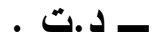

• شعراء الجاهلية بين الأوطان وبلاط الملوك : د / محمــ أحمـــ

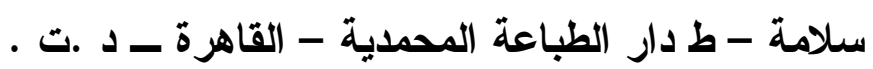

• شعراء معاصرون : أحمد مصطفى حسافظ - ط مطــابع الهيئسة

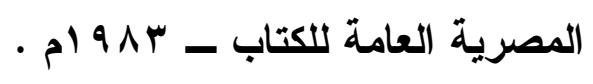

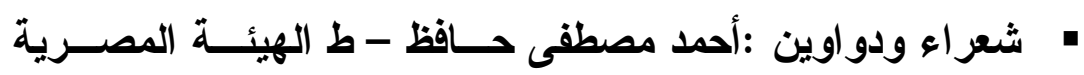

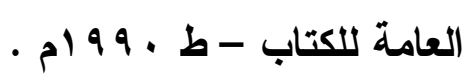

• شعراء الوطنية فى مصر:عبد الرحمن الرافعى - ط دار القومية

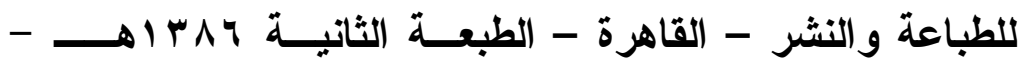

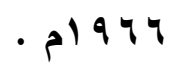

• الثوقيات : شعر المرحوم أحمد شوقى - الناثــر دار الكتــاب

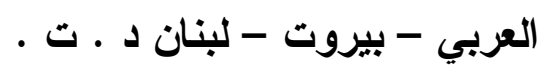

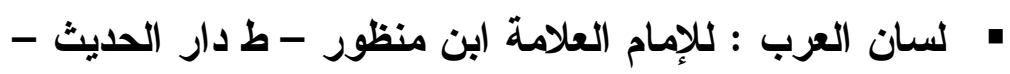

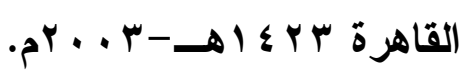


- $71 r-$ 